easibility of

Iround-Water Features of he Alternate Plan for the Mountain Home Project daho

EOLOGICAL SURVEY WATER-SUPPLY PAPER 1376

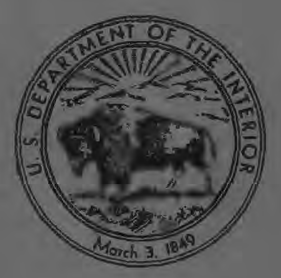





\section{Feasibility of}

\section{Ground-Water Features of}

the Alternate Plan for the Mountain Home Project Idaho

By R. L. NACE, S. W. WEST, and R. W. MOWER

GEOLOGICAL SURVEY WATER-SUPPLY PAPER 1376

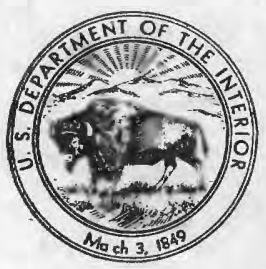




\section{UNITED STATES DEPARTMENT OF THE INTERIOR}

Fred A. Seaton, Secretary

\section{GEOLOGICAL SURVEY}

Thomas B. Nolan, Director 


\section{CONTENTS}

Abstract

Introduction _. 3

Reason for the report. 3

Field work and acknowledgments._....... 5

Well-numbering system

Background and definition of the alternate-plan proposal

The original plan for the Mountain Home project.

Development in the Boise Valley ......... 8

Irrigation. 8

The drainage problem

The alternate plan for the Mountain Home project.

Surface-water utilization

Pumping ground water in the Boise Valley

Environment in which the atternate plan would operate

Population and economic development._. 12

Agriculture and industry.

Electric power.

Water utilization

Surface water

Ground water.

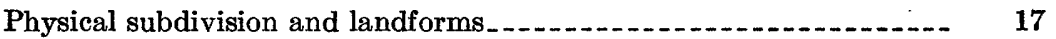

Valley of the Snake River.

Mountain Home plateau. . .

Boise Valley . . . .

Geologic factors in the occurrence of water. 19

Climatic factors.

Precipitation

Temperature_._. 28

Wind and evapotranspiration. . .

Topographic factors influencing water supply _....... 30

Water management._... 33

General water-supply patterns...... 34

Valley of the Snake River.

Mountain Home plateau.

Boise Valley . .

Total water supply _.

Surface water

Usable supply

Surface-water depletion.

Ground water............ 41

Water from the eastern upland. 41

Water from the northern highland..................... 43

Recharge from lowland precipitation.................. 44

Recharge from irrigation.......... 46

Ground-water depletion . . 
Limitations to the alternate plan imposed by the environment........

Limiting ground-water conditions.....

Nampa district........

Meridian district.

Wilder district.

Kuna district. . .

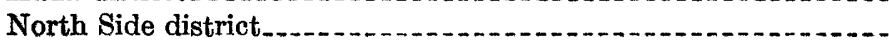

Withdrawal capacity and drainage effect of wells . .

Aquifer characteristics.

Performance of wells.........

Ground-water movement

Depth to water and water-level changes..........

Examples from typical areas. . . . .

Pioneer Irrigation District. .

Ellis farm . . .

Ustick-Meridian area...........

Eagle Island . .

Suitability of the water for irrigation

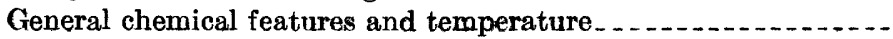

Classification of the water for irrigation use

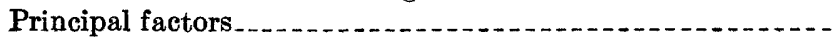

Classification according to percent sodium

Classification according to sodium-adsorption ratio...........

Classification by residual sodium-carbonate content.........

Comparison of the three classifications . . . . . . . . . . . . .

Uncommon and minor factors in irrigation suitability

Origin of the water-quality pattern

Natural factors

Effects of irrigation.

Salt balance...............

Feasibility of the alternate plan. .

Basic proposals and assumptions of the alternate plan...........

Diversion requirement for Mountain Home project..................

Availability of Boise River water.....

Exchangeability of Snake River water...........

Exchangeability of Boise Valley ground water.

Exchange water....................

Offset water . . . . . . . .

Total replacement water

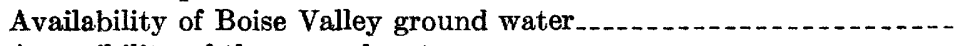

Accessibility of the ground water....

Well distribution and characteristics. . . .

Capacity and number of wells.......

Distribution of wells. . . . .

Effect on percolation loss from canals

Interference among wells. .

Depth and pumping lift.

Drainage benefits

Cost of wells and pumps.

Chemical suitability of replacement water

Principal conclusions.

Competence of available data.

General evaluation of the alternate plan.

Suggested practical trial and study $\ldots \ldots$ 


\section{ILLUSTRATIONS}

\section{[Plates are in Pockrt]}

Plate 1. Geographic setting of the Mountain Home and Boise projects; Idaho.

2. Generalized geologic map of the Boise Valley, Idaho.

3. Map of the Boise Valley, Idaho, showing locations of wells and irrigation-district boundaries.

4. Map of the Boise Valley showing depth to water, 1953.

5. Map of the Boise Valley showing water-table contours, 1953.

6. Map of the Boise Valley showing depth to water, 1914.

7. Chemical character of representative ground waters from the Boise Valley, Idaho.

FIGURE 1. Index map of southern Idaho showing the area covered by this

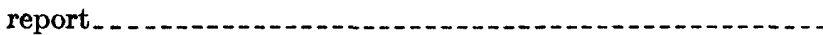

2. Sketch showing well-numbering system

3. Rise of the water level in well $4 \mathrm{~N}-4 \mathrm{~W}-34$ bc, 1912-1921 .....

4. Water-level fluctuations and small cumulative net rise of water table in well $2 \mathrm{~N}-2 \mathrm{~W}-10 \mathrm{ac1}, 1918-1953 \ldots \ldots$

5. Utilization of water in the Boise Valley . . . . . . . .

6. Double-mass plot for adjusting mean annual precipitation at two stations with short records

7. Provisional isohyetal map of the Boise River basin .........

8. Graph illustrating variations in precipitation at different altitudes.

9. Generalized cross section south of Boise River at Boise, showing relation of water table to land surface in summer of 1953.

10. Comparison of total monthly precipitation at Boise Airport with water-level fluctuations in well $3 \mathrm{~N}-1 \mathrm{E}-5 \mathrm{aal}$ during 1953

11. Areas that need drainage and area in which dual-purpose pumping would be feasible in the Boise Valley

12. Schematic sectional diagram illustrating the influence of impervious and recharge boundaries on the cone of depression around a pumped well

13. Schematic sectional diagram illustrating effects of interfering cones of depression around two pumped wells

14. Hydrographs of wells $2 \mathrm{~N}-3 \mathrm{~W}-9 \mathrm{ba} 1$ and $2 \mathrm{~N}-1 \mathrm{~W}-4 \mathrm{dd} 1$ for the period 1915-53, showing long-term net rise of water table....

15. Hydrograph of well $4 \mathrm{~N}-2 \mathrm{E}-31 \mathrm{cc}$ for the period 1914-52, showing seasonal and other fluctuations and long-term net rise of water table

16. Comparison of total yearly precipitation at Boise Airport with water-level fluctuations in wells $4 \mathrm{~N}-1 \mathrm{~W}-36 \mathrm{da} 1$ and $3 \mathrm{~N}-2 \mathrm{~W}-$ 25aa1, 1911-53

17. Seasonal water-level fluctuations in wells $2 \mathrm{~N}-2 \mathrm{~W}-13 \mathrm{bal}$ and $1 \mathrm{~N}-2 \mathrm{~W}-4 \mathrm{bc1}$ 
Frgure 18. Block diagram showing generalized subsurface conditions from the Ellis farm northward . .

19. Chemical character of waters from the Boise River at selected stations and seasons.

20. Variations of ground water temperature with depth, and comparison to typical and inferred thermal gradients..........

21. Classification of Boise Valley waters according to percent

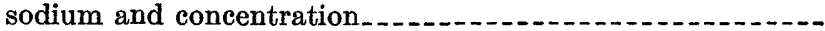

22. Classification of Boise Valley waters according to sodium-

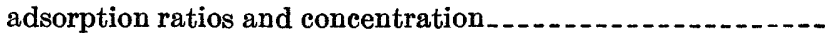

23. Mean monthly percolation losses or gains and mean monthend storage content of Lake Lowell reservoir, 1931-50.... -

24. Yearly percolation losses from Lake Lowell reservoir for the years 1931-50.

\section{TABLES}

Table 1. Principal Federal storage and diversion works, Boise River basin, Idaho . .

2. Population growth in Ada, Canyon, and Elmore Counties,

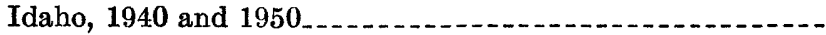

3. Agricultural statistics for the State of Idaho and for Ada and Canyon Counties, 1950

4. Installed capacity and production from power plants........

5. Utilization of water in the Boise Valley and Mountain Home plateau, 1953

6. Average yearly disposition of Boise River water, 1931-50, in acre-feet per calendar year.

7. Summary of the physical and hydrologic characteristics of geologic formations and other rock units

8. Average monthly precipitation in inches at stations in Ada, Canyon, and Elmore Counties.

9. Precipitation in inches at weather stations in or near the Boise River basin, 1931-50.

10. Precipitation at stations used for construction of isohyetal map of Boise River basin

11. Estimated volume of average annual precipitation on the Boise River basin . . .

12. Average temperature in degrees Fahrenheit at stations in Ada,

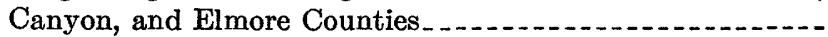

13. Estimated average evaporation from open-water surfaces, Arrowrock Reservoir and Lake Lowell _................

14. Duty of surface water for irrigation in Boise Valley .......--

15. Estimated disposition of precipitation in Boise River basin...-

16. Estimated effective total water supply of Boise Valley above Notus

17. Approximate hydraulic coefficients of some aquifers in the Boise Valley

18. Estimated drawdown of water table or artesian-pressure surface at given times and distances from pumped wells in Boise Valley 
$\mathbf{T}_{\text {ABLE 19. }}$ 19. Aquifer characteristics in typical areas._.................. 57

20. Specific capacity of wells in the Boise Valley

21. Estimated potential yield from pumped wells in the Boise Valley

22. Summary of chemical analyses of water.............. 72

23. Classification of irrigation waters in Boise Valley

24. Distribution of analyzed samples among irrigation-suitability classes.

25. Chemical analyses of waters in the Boise Valley........... 86

26. Feasibility of specific elements of the alternate plan........ 109 



\title{
FEASIBILITY TOF GROUND-WATER FEATURES OF THE ALTERNATE PLAN FOR THE MOUNTAIN HOME PROJEGT, IDAHO
}

\author{
By R. L. NACE, S. W. West, and R. W. Mower
}

ABSTRACT

An early plan of the U. S. Bureau of Reclamation proposed to irrigate 183,000 acres on the arid Snake River Plain south of Boise, Idaho (Mountain Home project) with Boise River water. That water would have been replaced to the Boise Valley with water imported from the Payette River. An alternate plan, proposed in 1953, would divert water from the Boise River to the plain; part of the water would be replaced by pumping ground water in the Boise valley and by importing water from the Snake River. Pumping of ground water in the Boise Valley also would help to drain waterlogged land. The present report evaluates the feasibility of the alternate plan in relation to geology and the occurrence and quality of ground water.

The mean annual temperature at Boise is $50.8^{\circ} \mathrm{F}$ and there is an average of 172 days between killing frosts. The annual evaporation rate from open-water surfaces in the area is about 33 inches. Runoff in the Boise River is chiefly from precipitation on mountain slopes at altitudes above 3,000 feet, east of Boise Diversion Dam. The surface-water supply of the Boise Valley is more than ample for the valley, owing to large upstream storage and regulatory dams and reservoirs. The valley also contains a large volume of ground water in storage, and the perennial rate of recharge is large. The computed consumptive depletion of surface water in the valley is nearly 600,000 acre-feet a year. Apparent depletion, computed from adjusted runoff at Notus, is 1,070,000 acre-feet. The difference of 470,000 acre-feet represents ground-water underflow and ungaged surface outflow from the area east of Notus.

After the beginning of irrigation, around the turn of the century, the water table in the Boise Valley rose steadily; the amount of rise at some places was as much as 140 feet. Shallow perched zones of saturation were created locally. More than 100,000 acres of Boise Valley land now is waterlogged or threatened with waterlogging, despite the presence of more than 325 miles of surface drains.

Successful operation of the alternate plan would depend, not only on providing adequate water to replace that exported from the Boise Valley, but also on satisfactory drainage of waterlogged land. That is, water management in the valley would have to couple economical pumping of irrigation water with effective drainage by pumping.

The average of recorded yearly diversions from the Boise River is 1,280,000 acre-feet of live water (natural flow, in a stream) and 201,000 acre-feet of recycled water. Gross diversions of record in some recent single years of ample water supply reportedly exceeded $1,800,000$ acre-feet. Ground water, on the other hand is used on a relatively small scale, yearly pumpage being only about 150,000 acre-feet. 
The feasibility of exporting 600,000 acre-feet of Boise River water would depend on the availability of replacement water in the Boise Valley and on the availability of the required surface water in the South Fork of the Boise River at the proposed point of diversion to the Mountain Home project. In 6 of the 20 years, 1931-50, recorded diversions of live and return water from the Boise River exceeded the live flow at the Boise Diversion Dam by 3,865 to 107,640 acre-feet. Moreover, although the average residual discharge in the river past Notus was 701,000 acre-feet, in most years some river reaches above Notus were dry at times, owing to diversion of all water from the river. Much of the flow past Notus is surface waste and effluent ground water, which averages about 422,000 acre-feet a year.

The total of potential yearly ground water recharge in the Boise Valley, derived from precipitation, incoming underflow, and infiltration of irrigation water, is about 554,000 acre-feet in the feasible exchange-pumping area and areas tributary thereto. Identified and estimated consumptive depletion of ground water in the valley is about 230,000 acre-feet a year, but not all that depletion is within the exchange area or area tributary thereto.

Five ground-water districts in the Boise Valley are defined, chiefly on the basis of well capacities. Wells in the district around Nampa tap both artesian and unconfined water and have the largest yields in the valley, averaging $1 \mathrm{cfs}$ for each 8 feet of drawdown. The average depth to the water table is between 10 and 15 feet and the maximum depth is 50 feet. Much waterlogging of land in the district is caused by upward leakage of artesian water through imperfectly confining layers of soil and caliche.

In the vicinity of Meridian and eastward the average depth to the water table is between 10 and 15 feet and the maximum depth is about 50 feet. Artesian aquifers underlie the district at various depths. Water-table wells yield about 1 cfs of water for each 22 feet of drawdown; artesian wells yield as much as $1.5 \mathrm{cfs}$ by natural flow and 3 efs by pumping. Drainage conditions are similar to those in the Nampa district.

The average depth to water and average yield of wells in the vicinity of Wilder and Kuna are not known. The permeability of the aquifers around Wilder is relatively low. Drainage is needed but the sediments do not drain by groundwater pumping as readily as those around Nampa and Meridian. In much of the Kuna area the depth to water is too great for economical pumping. The occurrence of ground-water north of the Boise River is too poorly known to be described adequately.

The apparent coefficient of transmissibility of aquifers tested at key locations in the Boise Valley ranges from 36,800 to 1,700,000 gpd per foot. Observed coefficients of storage of artesian aquifers range from 0.00007 to 0.001 ; those of nonartesian aquifers range from 0.001 to 0.43 . The specific capacities of wells range from 8 to $450 \mathrm{gpm}$ per foot of drawdown.

Typical areas in the Boise Valley can be benefitted by ground-water pumping for drainage, and appreciable lowering of water levels has been observed as much as half a mile from pumped wells. Field tests show that drainage benefits result also from the pumping and free flow of artesian wells under some circumstances. Discharge of ground water from shallow artesian aquifers would assist drainage by diminishing artesian pressure and upward leakage of water. Discharge from deeper aquifers does not produce noticeable local or immediate drainage benefit, but may cause regional benefits. In some areas conditions do not favor drainage by pumping ground water.

The amounts of dissolved solids in the surface water of the Boise Valley range from 51 to $788 \mathrm{ppm}$ in samples analyzed. The range in ground water is from 69 to $1,040 \mathrm{ppm}$. In general, the concentration of dissolved solids and the percent 
sodium, both in the ground water and in the surface water, increase westward (downstream). Most exchange ground water pumped under the alternate plan would be diluted with surface water, but some land would receive a preponderance of ground water. Thus, the chemical suitability of the ground water for irrigation is an important factor.

The sodium hazard (alkali hazard) and salinity hazard to soils from Boise Valley ground waters, represented by 88 samples, were evaluated by standard criteria. Most of the samples are excellent to good, a few are permissible to doubtful, and none are unsuitable. The surface waters generally are slightly superior in quaiity to the ground waters. Parts of the valley seem to be on the verge of an unfavorable salt balance, and whether depreciation in the quality of the water can be tolerated requires careful study.

In order to determine whether the alternate plan is physically feasible, could be operated successfully for an indefinitely long time, and would be advantageous to execute, the principal features of water management embodied in the plan are reviewed, one by one. Geologic factors suggest that the diversion requirement of water per unit of land in the Mountain Home project would be appreciably higher than that estimated in the alternate pian. If so, the area that could be irrigated with the proposed amount of water from the Boise River would be less than that stated in the alternate plan. The availability of 600,000 acre-feet of Boise River water for diversion to the Mountain Home project, at the times and places the water would be needed, has not been demonstrated. The run-ofthe-river supply in the South Fork of the Boise River was deficient in 6 of 20 recent years. Holdover storage at Anderson Ranch Dam and modified reservoir operation would be necessary for operation of the plan and would reduce the amount of water available for generation of firm power. Snake River water is available and the exchange for Boise River water is physically feasible to a limit of $\mathbf{3 0 0 , 0 0 0}$ acre-feet a year.

For the alternate plan to be acceptable to Boise Valley water users, an undiminished supply of irrigation water presumably must be assured. Such assurance is not possible at the proposed exchange rate of 225,000 to 300,000 acre-feet of ground water for an equal amount of river water. Additional water would need be pumped to compensate the effects of diminished surface water and diminished ground water in storage. To offset.the effects of exporting surface water, the amount of ground-water pumped would be substantially more than 300,000 acre-feet and might approach 400,000 acre-feet. In years of short water supply the total might approach 500,000 acre-feet.

Net ground-water depletion under the alternate plan would be on the order of 100,000 to 150,000 acre-feet a year. Return recharge of unconsumed ground water would lag somewhat after pumping, and temporary depletion at the end of the irrigation season would be less than gross pumpage but more than ultimate net depletion. Thus, though water to operate the alternate plan is available in the Boise Valley, it is not certain that the yearly demand could be withdrawn during the pumping season without local or temporary mining of water. Nor is it certain that mined water would be replenished each year before the onset of another irrigation season.

\section{INTRODUCTION}

\section{REASON FQR THE REPORT}

On the Snake River Plain south and southeast of Boise, Idaho, and east and north of the Snake River, is an area of about 750,000 acres of forbidding, arid sagebrush desert, here called the Mountain Home 


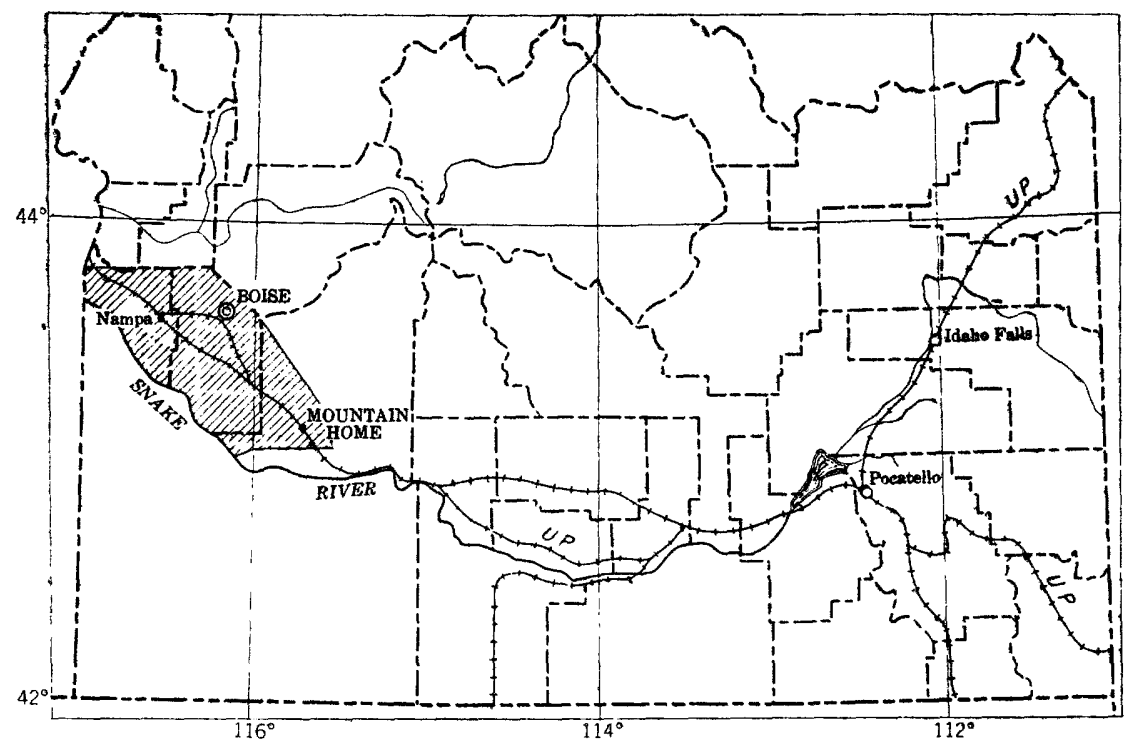

FrGURE 1.-Index map of southern Idaho showing the area covered by this report.

plateau (fig. 1, pl. 1). It contains more than 400,000 acres of arable land that is largely unused except for grazing. There are only a few small irrigated tracts near foothill slopes, and a scattered few dry farms. To bring water to the plateau has been the hope of two generations of reclamationists, public servants, and local citizens.

Adjacent to the undeveloped plateau is the fertile and prosperous Boise Valley, containing one of the largest integrated areas of irrigated land in Idaho, which has been reclaimed from wasteland similar to that in the plateau. This valley, however, is marred by waterlogged land, alkalized soil, and spreading native vegetation, all caused or aggravated by excess water. Conventional surface drains have been only moderately successful and the continued presence of excess water, chiefly in underground storage, has reduced the productivity of land in substantial parts of the Boise Valley and threatens the agricultural prosperity of the area. Industrial, business, and municipal operations also are hampered at some places by shallow ground water.

Irrigation of 340,000 acres of land in the Boise Valley has disrupted the original water balance. Irrigation water applied in excess of the consumptive-use demand for crops and native vegetation has gone into ground-water storage, has raised the water table, and has waterlogged thousands of acres of land. Records of ground-water levels, dating from about 1910, prove the large increase in permanently stored ground water. That water is the heart of the drainage problem in the Boise Valley. 
Irrigation on the relatively undeveloped Mountain Home plateau and drainage of the Boise Valley traditionally were regarded as unrelated separate problems. Formal proposals (herein called the original plan) were made by Newell in 1949 (U. S. Bur. Reclamation, 1950b) for a Mountain Home reclamation project to be constructed by the United States Bureau of Reclamation. Water for tbe project was to be obtained by means of extensive storage and diversion works, including a transmountain diversion from the Payette River basin.

An alternate plan, for partial irrigation of the Motrntain Home plateau, integrated with drainage in the Boise Valley, was proposed by W. G. Sloan (1953), consulting engineer, retained by the Idaho Power Ca. to study problems of irrigation and drainage in relation to the electric-power market. Under this plan the Boise Valley would be drained by pumping ground water, which would be used for irrigation in order to release and replace Boise River water that would be diverted to the Mountain Home plateau. Surplus water from the Boise River also would be used. Additional replacement water for use in the Boise Valley would be obtained from the Snake River.

The alternate plan proposal was brought to the attention of Congress and was printed, along with an analysis by James $\mathrm{K}$. Carr (1953), engineering consultant to the Committee on Interior and Insular Affoirs, U. S. House of Representatives. Carr's analysis was generally favorable but further study was suggested. Accordingly, in fiscal year 1954, Secretary of the Interior Douglas McKay directed the United States Bureau of Reclamation and the United States Geological Survey to make engineering, geologic, and hydrologic studies, and to evaluate the feasibility of the proposals in the alternate plan.

This report contains the evaluation by the Geological Survey of the feasibility of those parts of the plan that relate to geology and ground water, along with a summary of the basic information and principles upon which the evaluation is based. The evaluation is by no means exhaustive. The time allotted was too brief for more than nominal new factfinding. Thus, of necessity, qualified conclusions are drawn on points that could be resolved in full only after extensive and prolonged field investigation.

\section{FIELD WORK AND ACKNOWLEDGMENTS}

Special field work and study by the Geological Survey for the purpose of evaluating the alternate plan was begun in May 1953 and completed in December 1953. The Bureau of Reclamation collaborated in the field by contracting for drilling and pumping test and observation wells, by furnishing part of the essential equipment, and by spirit leveling to many well sites. The Pioneer Irrigation District 
permitted the use of some of its wells and pumps for pumping tests; the Idaho Power Co. supplied electric power and some equipment for pumping tests; and the Surface Water Branch of the Geological Survey made special miscellaneous stream-discharge measurements, made field checks of small reservoirs and diversions, checked and evaluated compilations of surface-water records, and reviewed the adequacy of surface-water data. Field work by or under the supervision of the authors consisted principally of geologic study and mapping, canvassing and measuring wells, operating observation wells, logging and testing wells, making pumping tests, and collecting samples of water and geologic materials. The authors were assisted in various phases of the field work by F. E. Fennerty, R. C. Scott, Eugene Shuter, and G. E. Brandvold, all of the Geological Survey. T. R. Newell,and T. R. Miller assisted in the compilation, evaluation,

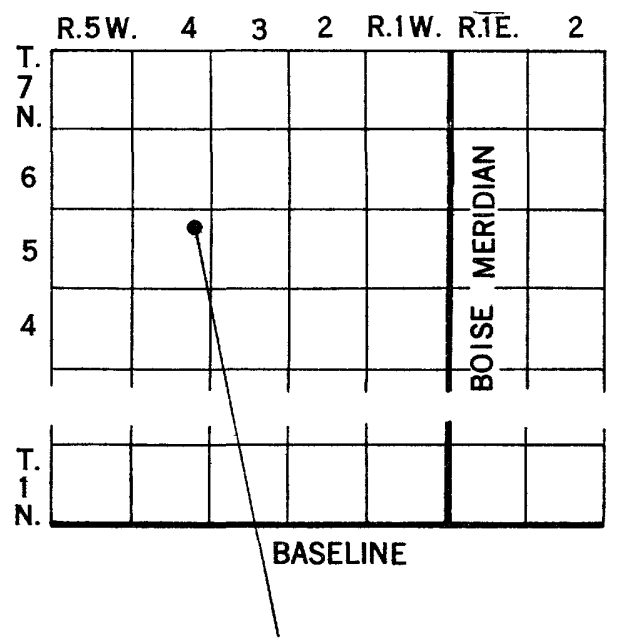

WELL NO $5 \mathrm{~N}-4 \mathrm{~W}-12 \mathrm{~cd} 1$

\begin{tabular}{|c|c|c|c|c|c|}
\hline \multicolumn{6}{|c|}{ R. $4 \mathrm{~W}$. } \\
\hline 6 & 5 & 4 & 3 & 2 & 1 \\
\hline 7 & 8 & 9 & 10 & 11 & $/ 12$ \\
\hline 18 & 17 & 16 & 15 & 14 & 13 \\
\hline 19 & 20 & 21 & 22 & 23 & 24 \\
\hline 25 & 26 & 27 & 28 & 29 & 30 \\
\hline 31 & 32 & 33 & 34 & 3 & 36 \\
\hline
\end{tabular}

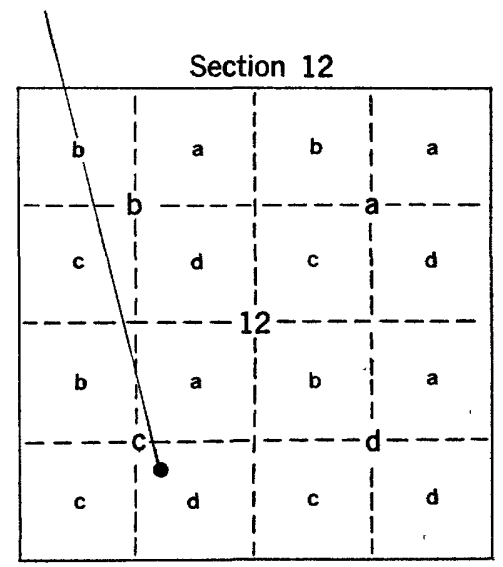

FiguRE 2.-Sketch showing well-numbering system. 
and interpretation of surface-water data. Chemical analyses of water were made in the Geological Survey's laboratory at Corvallis, Oreg.

Records of the discharge of the Boise River have been collected by the Geological Survey and published annually since 1896. Records of ground-water levels, river-water diversions, and discharge from surface drains, along with copies of unpublished maps and reports, all representing nearly 50 years of water history, were made available to the Geological Survey by the Bureau of Reclamation, the Boise Project Board of Control, the Nampa-Meridian Irrigation District, and the Pioneer Irrigation District. Records from intermittent and short-term studies of ground water in local small areas, made in cooperation between the Geological Survey and the Idaho Department of Reclamation, have been used. Civic officials, well drillers, and many well owners furnished well records and logs and permitted access to wells. Especially useful information was obtained from well drillers A. E. Hosack and Son, Orval Harden, Jack Dir, and Leonard Davis.

\section{WELL-NUMBERING SYSTEM}

Water wells are referred to in this report by numbers that indicate their locations within legal rectangular subdivisions of the public lands, with reference to the Boise baseline and meridian (fig. 2). The first two segments of a number designate the township and range. The third segment gives the section number, followed by two letters and a numeral, which indicate the quarter section, the 40 -acre tract, and the serial number of the well within the tract. Quarter sections are lettered $a, b, c$, and $d$ in counterclockwise order, from the northeast quarter of each section. Within the quarter sections 40-acre tracts are lettered in the same manner. Well $5 \mathrm{~N}-4 \mathrm{~W}-12 \mathrm{~cd} 1$ is in the $\mathrm{SE}^{1 / 4} \mathrm{SW} 1 / 4$ sec. 12 , T. $5 \mathrm{~N}$., R 4 W., and is the well first visited in that traet.

\section{BACKGROUND AND DEFINITION OF THE ALTERNATE- PLAN PROPOSAL}

In order to set the features of the alternate plan for the Mountain Home project in proper perspective for evaluation, it is appropriate to review the development of the Boise Valley and the general features of the original plan for the Mountain Home project.

\section{THE ORIGINAL PIAN FOR THE MOUNTAIN HOME PROJECT}

The original plan for the Mountain Home project (U.S. Bur. Reclamation, 1950b) proposed to irrigate a net area of 183,000 acres in the Payette unit, divided between the Hillcrest and Long Tom divisions, which would contain 83,300 and 100,300 acres respectively (pl. 1). From the proposed Garden Valley reservoir on the Payette River, water for the Hillcrest division would be diverted through the Moore 
Creek tunnel, 30 miles long, to the Moore Creek arm of Lucky Peak Reservoir in the Boise River watershed. Water would be diverted to the Long Tom division from storage in Anderson Ranch Reservoir. Most of the water from Anderson Ranch Reservoir, now used on the Boise project, would be replaced with water imported from the Payette River.

\section{DEVELOPMENT IN THE BOISE VALLEY}

\section{IRRIGATION}

Water for irrigation in the Boise Valley was first diverted from the Boise River in 1864 with simple ditch diversions leading to valley bottom lands (U. S. Bur. Reclamation, 1950a, p. 156). Cooperative farmer groups later built small diversion dams and canals, and by 1900 about 148,000 acres of lowland was under irrigation. The Boise project (pl. 1), one of the oldest Federal reclamation projects, was authorized soon after passage of the Federal Reclamation Act of 1902, and construction was begun in 1904. The project included a gross area of 187,000 acres, containing 166,000 irrigable acres. Water was first delivered in 1906, and the originally planned impounding and diversion works were substantially completed in 1915. By 1927 the feeder canals and other supplemental structures had been extended to the full irrigable area of 166,000 acres. The estimated net area now actually irrigated in the Government project is 150,000 acres. About 190,000 acres is privately irrigated and the estimated net area irrigated with surface water thus is 340,000 acres (U. S. Bur. Reclamation, $1950 \mathrm{a}$, p. 156). We estimate that at least 10,000 additional acres is irrigated solely with ground water, and probably more than 40,000 acres under the surface-water system receives supplemental ground water.

The principal original government-project storage and diversion works (see table 1) are Arrowrock Dam and Reservoir, Boise Diversion Dam, and Lake Lowell (Deer Flat Reservoir). Anderson Ranch Dam was erected later to provide supplemental storage for the Boise project. Lucky Peak Dam is primarily a flood-control structure, but certain water power and storage features can be integrated with the Mountain Home project under either the original or the alternate plan. Barber Dam, several miles below Boise Diversion Dam, is a diversion structure for private irrigation districts and for private power generation. Hubbard Reservoir, near the point where Tenmile Creek enters the Boise project area, has a reported capacity of 7,500 acre-feet, and is filled with water for the project.

On the Mountain Home plateau the Long Tom, Mountain Home, Orchard, and Pleasant Valley Reservoirs store early spring runoff and have a reported total capacity of 20,750 acre-feet. An intermountain diversion from Little Camas Reservoir delivered an average of 9,000 
acre-feet of water per year to the Canyon Creek basin above Long Tom Reservoir during the period 1931-50.

TABLe 1.-Principal Federal storage and diversion works, Boise River basin, Idaho

\begin{tabular}{|c|c|c|c|c|c|c|}
\hline \multirow[b]{2}{*}{ Name } & \multirow[b]{2}{*}{ Nature or purpose } & \multirow[b]{2}{*}{ Location } & \multirow{2}{*}{$\begin{array}{l}\text { Sur- } \\
\text { face } \\
\text { area } \\
\text { (acres) }\end{array}$} & \multirow{2}{*}{$\begin{array}{c}\text { Date } \\
\text { of com } \\
\text { ple- } \\
\text { tion }\end{array}$} & \multicolumn{2}{|c|}{ Storage capacity } \\
\hline & & & & & $\underset{\text { (acre-ft) }}{\text { Gross }}$ & $\begin{array}{l}\text { Net us- } \\
\text { able } \\
\text { (aere-ft) }\end{array}$ \\
\hline $\begin{array}{l}\text { Anderson } \\
\text { Dam and Ranch } \\
\text { voir. }\end{array}$ & $\begin{array}{l}\text { Multiple purpose: ir- } \\
\text { rigation, power, } \\
\text { flood and silt con- } \\
\text { trol }\end{array}$ & $\begin{array}{l}\text { On South Fork Boise } \\
\text { River about } 65 \mathrm{mi} \\
\text { upstream from } \\
\text { Boise. }\end{array}$ & 4,740 & 1950 & 493,200 & 464,200 \\
\hline $\begin{array}{l}\text { Arrowrock Dam } \\
\text { and Reservolr. }\end{array}$ & Irrigation storage..... & $\begin{array}{l}\text { On Boise River about } \\
23 \text { mi upstream from }\end{array}$ & 3,150 & 1915 & 1286,600 & 286,600 \\
\hline $\begin{array}{l}\text { Luoky Peak Dam } \\
\text { and Reservoir. }\end{array}$ & $\begin{array}{l}\text { Primary use, flood } \\
\text { control; secondary } \\
\text { use: irrigation; po- }\end{array}$ & $\begin{array}{l}\text { On Boise River about } \\
9 \text { mi upstream from } \\
\text { Boise. }\end{array}$ & $\ldots . .$. & 1955 & 280,000 & $280,000(?)$ \\
\hline $\begin{array}{l}\text { Boise Diversion } \\
\text { Dam. }\end{array}$ & $\begin{array}{l}\text { Irrigation diversion } \\
\text { and power. }\end{array}$ & $\begin{array}{l}\text { On Boise River aboat } \\
7 \text { mi upstream from }\end{array}$ & & 1908 & $0+$ & $0+$ \\
\hline $\begin{array}{l}\text { Lake Lowell (reser- } \\
\text { volr). }\end{array}$ & $\begin{array}{l}\text { Irrigation storage, fish, } \\
\text { and wildlife. }\end{array}$ & $\begin{array}{l}\text { Off-river structure } \\
\text { about } 6 \text { mi south of } \\
\text { Caldwell; fed by } \\
\text { canal. }\end{array}$ & 9,835 & 21911 & 190,150 & 8169,200 \\
\hline Total & & 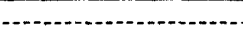 & & & $1,249,950$ & $1,200,000$ \\
\hline
\end{tabular}

1 The original storage capacity of Arrowrock Reservoir was 276,500 acre-feet. The dam was raised 5 feet in 1936, giving additional starage space for 10,100 acre-feet of water.

2 Dam and reservoir construction were sufficiently advanced for operational use in 1909.

3 Original usable capacity was 177,150 acre-feet.

\section{Tei dRATNAGE PROBLEM}

Many miles of drainage canals and ditches in the Boise Valley have alleviated the drainage problem without solving it, and new drainage works are constructed each year. The irrigated area is a maze of interlocking drains and canals which occupy thousands of acres of land that might otherwise be producing crops. Excavation of open drains was begun in 1914 and by 1921 there were 127 miles of drains in the valley. The number of miles currently in use is estimated to be appreciably more than 325. Parts of the Boise Valley are organized in drainage districts, counterparts of the irrigation districts, the costs for which are in addition to the costs of irrigation and project development.

After 1927 the Pioneer Irrigation District established a substantial and satisfactory drainage-well field, and some drainage wells were drilled in the Nampa-Meridian Irrigation District. Nearly 200 wells for drainage and irrigation have been drilled in the valley by private initiative, but there has not been concerted, systematic, valley-wide action on the ground-water problem.

Records of water levels in wells in the Boise Valley show that the water table began to rise markedly about 1912, nearly reaching a maximum at some places within a few years (fig. 3). Apparently the general, valley-wide buildup of ground-water storage nearly reached 


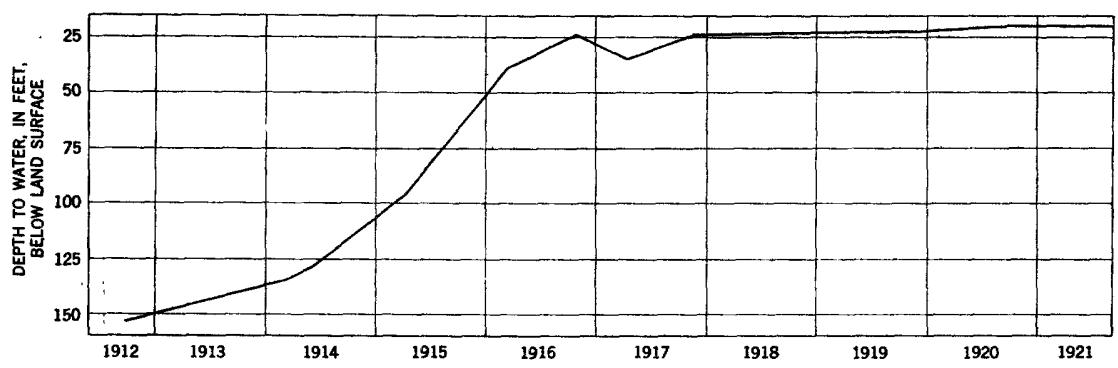

Figure 3.-Rise of the water level in well $4 \mathrm{~N}-4 \mathrm{~W}-34 \mathrm{bc}, 1912-21$.

a maximum in the middle or late 1930's, shortly after most of the irrigable area was brought under irrigation. Since then the buildup has been less rapid, and in some localities there has been little net change in water levels for many years (fig. 4). Nevertheless, water levels have continued to rise gradually in some areas.

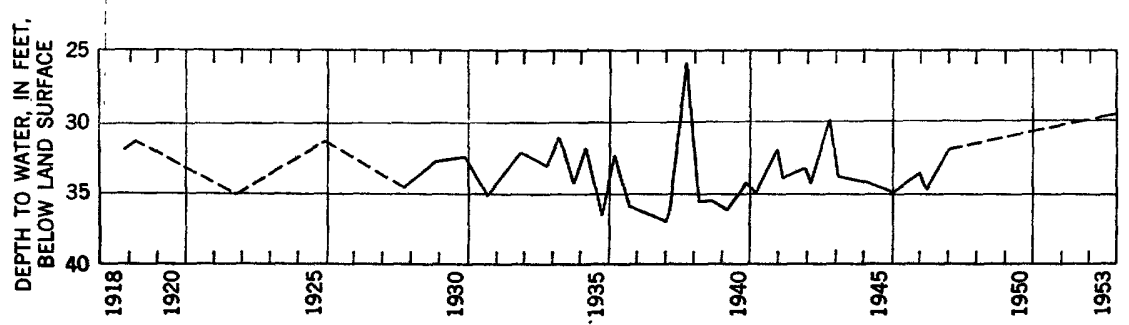

Fraure 4.-Water-level fluctuations and small cumulative net rise of water table in well $2 \mathrm{~N}-2 \mathrm{~W}-10 \mathrm{ac1}$, 1918-53.

The importance of the ground water and its relation to the drainage problem was pointed out by Steward (1919). Carter (1926) advocated more efficient use of surface water to serve a larger area, drainage relief by pumped wells, and use of pumped water to supplement surface water for irrigation. He noted that beneath 125,000 acres of land in the Boise Valley (more than one-third of the irrigated area) the water table was less than 15 feet below the land surface and that ground water might be pumped to relieve water shortages in drought years. Marr $^{1}$ summarized some aspects of the problem and Carter ${ }^{2}$ estimated that about 40,000 acre-feet of ground water for irrigation could be pumped annually in the Nampa-Meridian Irrigation District. A proposal for more comprehensive water management, including pumping of ground water, was prepared in 1936 by the Bureau of Reclama-

\footnotetext{
1 Marr, J. C., 1936, Preliminary report on drainage requirements of Boise Valley, Idaho, with respect to the proposed Salmon River development, Exhibit 8 in Riter, J. R., and Keimig, J. A., Boise River Investigations, U. S. Bur. Reclamation rept. (mimeographed), p. 207-212, April.

2 Carter, George N., 1936, "Pumping ground water for supplemental irrigation supply, Boise Valley," Exhibit A in Riter, J. R., and Keimig, J. A., Boise River in vestigations, U. S. Bur. Reclamation rept. (mimeographed), p. 174-206, A pril.
} 
tion. ${ }^{3}$ Piper, ${ }^{4}$ of the Geological Survey, proposed systematic investigations of ground-water conditions. A comprehensive, valley-wide study of water resources, with special emphasis on the ground-water and drainage problem, was proposed by the senior author, ${ }^{5}$ also of the Geological Survey.

\section{THE ALTERNATE PLAN FOR THE MOUNTAIN HOME PROJECT}

The alternate plan for the Mountain Home irrigation and drainage project, proposed by Sloan (1953), is defined, described, and given preliminary analysis in Committee Print No. 4, House Committee on Interior and Insular Affairs, "83d Congress (see Carr, 1953). The Committee Print is the version of the plan upon which the analysis in the present report is based.

The alternate plan contemplates comprehensive water management, including integration of drainage benefits in the Boise Valley with development and irrigation of new land on the Mountain Home project. Essential features of the proposal are to pump 225,000 to 300,000 acre-feet of ground water per year in the Boise Valley to drain wet land and provide irrigation water; to pump 150,000 acre-feet of water yearly from the Snake River into Lake Lowell to supply irrigation water to western parts of the Boise Valley; to divert 600,000 acre-feet of water annually from the Boise River system above the Boise Diversion Dam for irrigation of divisions of the Mountain Home project; to generate electric power at three installations. It would include 12,000 acres in the Hillcrest division and 111,000 acres in the Long Tom division, or about 69 percent of the net available arable area in the Payette unit.

\section{SURFACE-WATER UTILIZATION}

A diversion dam or pumping station below Lucky Peak Reservoir would supply 60,000 acre-feet of water annually to a main canal and laterals serving 12,000 acres in the Hillcrest division. The remaining 71,300 acres in the Hillcrest division of the original plan would not be irrigated. Diversion from the South Fork of the Boise River, by essentially the same means as in the original plan, would provide 540,000 acre-feet of water per year to 111,000 acres in the Long Tom division. The total volume of diversions from the Boise River system to the Mountain Home project thus would be 600,000 acre-feet a year.

The alternate plan proposes to pump 150,000 acre-feet of water yearly from the Snake River into Lake Lowell, in exchange for an equal amount of Boise River water diverted to the Mountain Home

3 Riter, J. R., and Keimig, J. A., 1936, Boise River Investigations: U. S. Bur. Reclamation rept. (mimeom graphed), 212 p., April.

4 Piper, A. M., 1936, Unpublished administrative report.

- Nace, R. L., 1949, Unpublished administrative report. 
project. Additional water would be pumped into Lake Lowell, using low-value electric power during off-peak power-consumption periods. During peak periods water would be discharged by gravity baek down the penstock to generate high-value power. In addition, generating facilities at Lucky Peak Dam would have an installed capacity of 48,000 kilowatts and a production of 235 million kilowatt-hours in a median year. An installation on the Long Tom diversion would have an installed capacity of 23,000 kilowatts and an estimated production of 81 million kilowatt-houks in a median year.

\section{PUMPING GROUND WATHR IN THE BOISE VALTEY}

Under the alternate plan 225,000 to 300,000 acre-feet of ground water in the Boise Valley would be pumped yearly in exchange for Boise River water diverted to the Mountain Home project. About 450 wells would be drilled at quarter-mile intervals adjacent to existing principal canals in the valley, and water from the wells would be pumped into the canals during an average yearly period of 125 days. Pumping the wells supposedly would drain waterlogged lands by lowering the water table $4 \frac{1}{2}$ to 5 feet beneath 225,000 acres of land" in the Boise Valley. Wells supposedly would have an average depth . of 60 feet and an assumed average yield of $2 \mathrm{cfs}$, giving a total installed : pumping capacity of $900 \mathrm{cfs}$. In years of short supply of surface water ground-water pumpage would be increased to as much as 300,000 acre-feet. The plan assumes that construction of new canals would not be necessary in the Boise Valley because pumps would discharge water directly to main canals.

\section{ENVIRONMENT IN WHICH THE ALTERNATE PLAN WOULD OPERATE}

\section{POPULATION AND ECONOMIC DEVELOPMENT}

The Boise Valley had about 131,000 inhabitants in 1950 , or about 21 percent of the total State population. The populations of complete counties that include parts of the valley, and the principal towns, are shown in table 2. The basic economy of the valley is agricultural and depends principally on the natural resources in land and water. Farming by irrigation is done chiefly in parts of Ada, Canyon, and Elmore Counties.

\section{AGRICULTURE AND INDUSTRY}

The irrigated area in the Boise Valley is served by several hundred miles of canals and laterals, maintained and operated by about 14 organized irrigation districts. Smaller canal systems serve areas near Mountain Home. Statistics (table 3) illustrate the relative importance of agriculture in Idaho and in the principal two counties in the Boise Valley. According to data in the office of the Ada County assessor, 
the value of farm production in Ada and Canyon Counties in 1953 was 24 million dollars.

The chief industries in the area are based on agriculture and include food packing and processing, fertilizer manufacture, and fabrication of farm equipment and machinery. There are also lumber mills, metal foundries and machining plants, and related industries.

TABLE 2.-Population growth in Ada, Canyon, and Elmore Counties, Idako, 1940 and 1950

[Based on data published by the U. S. Bureau of the Census]

\begin{tabular}{|c|c|c|c|}
\hline \multirow{2}{*}{ County and town } & \multicolumn{2}{|c|}{ Year } & \multirow{2}{*}{$\begin{array}{l}\text { Percent } \\
\text { inerease }\end{array}$} \\
\hline & 1940 & 1950 & \\
\hline $\begin{array}{l}\text { Ada County } \\
\text { Boise } \\
\text { Meridian. } \\
\text { Garden City } \\
\text { Kuna. }\end{array}$ & $\begin{array}{r}50,401 \\
26,130 \\
1,465 \\
443\end{array}$ & $\begin{array}{r}70,649 \\
34,393 \\
1,810 \\
764 \\
584\end{array}$ & $\begin{array}{r}40.2 \\
31.6 \\
23.5 \\
20.5\end{array}$ \\
\hline $\begin{array}{l}\text { Canyon County } \\
\text { Nampa } \\
\text { Caldwell } \\
\text { Parma. } \\
\text { Wilder } \\
\text { Middleton. } \\
\text { Notus. }\end{array}$ & $\begin{array}{r}40,987 \\
12,149 \\
7,272 \\
1,085 \\
507 \\
477 \\
277\end{array}$ & $\begin{array}{r}53,597 \\
16,185 \\
10,487 \\
1,369 \\
555 \\
496 \\
313\end{array}$ & $\begin{array}{r}30.8 \\
33.2 \\
44.2 \\
26.2 \\
9.5 \\
4.0 \\
13.0\end{array}$ \\
\hline $\begin{array}{l}\text { Elmore County } \\
\text { Mountain Home } \\
\text { Glenns Ferry }\end{array}$ & $\begin{array}{l}5,518 \\
1,183 \\
1,290\end{array}$ & $\begin{array}{l}6,687 \\
1,887 \\
1,515\end{array}$ & $\begin{array}{l}21.2 \\
58.2 \\
17.4\end{array}$ \\
\hline
\end{tabular}

TABLE 3.-Agricultural statistics for the State of Idaho and for Ada and Canyon Counties, 1950

[Based on data from U. S. Census of Agriculture, 1950]

\begin{tabular}{|c|c|c|c|}
\hline Item & $\begin{array}{c}\text { State of } \\
\text { Idaho }\end{array}$ & $\begin{array}{l}\text { Ada } \\
\text { County }\end{array}$ & $\begin{array}{l}\text { Canyon } \\
\text { County }\end{array}$ \\
\hline $\begin{array}{l}\text { Farmiand (ineluding irrigated land): } \\
\text { Number of farms } \\
\text { Average size of farms } \\
\text { Value of land and buildings: } \\
\text { A verage per acre. } \\
\text { Total } \\
\text { Irrigated land: } \\
\text { Number of irrigated farms } \\
\text { Average size of irrigated farms } \\
\text { Vahue of land and buildings: } \\
\text { Average per acre } \\
\text { Total } \\
\text { Tivestock: Total value } \\
\text { Crops: } \\
\text { Total area in crops. } \\
\text { Value of crops }\end{array}$ & $\begin{array}{r}40,284 \\
328.3 \\
\$ 73.01 \\
\$ 965,498,257 \\
29,413 \\
271.3 \\
\$ 83.71 \\
\$ 668,026,643 \\
\$ 146,256,660 \\
4,542,454 \\
\$ 212,937,881\end{array}$ & $\begin{array}{r}2,503 \\
156.1 \\
\$ 123.10 \\
\$ 48,053,487 \\
2,405 \\
109.7 \\
\$ 169.90 \\
\$ 44,828,624 \\
\$ 6,838,874 \\
73,103 \\
\$ 5,081,019\end{array}$ & $\begin{array}{r}3,985 \\
74.3 \\
-\quad \$ 231.37 \\
\$ 68,484,131 \\
3,873 \\
74.9 \\
\$ 231.06 \\
\$ 67,062,392 \\
\$ 8,508,562 \\
148,267 \\
\$ 19,136,364\end{array}$ \\
\hline
\end{tabular}

\section{GLECTRIC POWER}

The Boise Valley is served by an extensive power-transmission system from which only new leads or laterals would be needed to supply new pumping facilities. The Mountain Home plateau is traversed on the northeast by a high-tension line and is ringed by transmission systems. 


\section{THE ALTERNATE 'PLAN, MOUNTAIN HOME PROJECT; IDAFO}

The electric-power potential of the Boise, Snake, and Payette Rivers is largely undeveloped (table 4). Low-head plants of the Idaho Power Co. at Boise Diversion and Barber Dams on the Boise River generate interruptible power from water that is not diverted in the New York (Main) Canal: Interruptible power is generated by Government plants at Anderson Ranch Dam on the South Fork of the Boise River and at Black Canyon Dam on the Payette River. Firm (constant-rate) power is generated by plants of the Idaho Power Co. on the Snake River at Swan Falls and at the C. J. Strike Dam.

TABLE 4.-Installed capacity and production from power plants

[Based on data furnished by Idaho Power Co. and on published reports of the U. S. Bureau of Reclamation]

\begin{tabular}{|c|c|c|}
\hline Name of dam & $\begin{array}{c}\text { Installed } \\
\text { capacity } \\
\text { (kw) }\end{array}$ & $\begin{array}{l}\text { Production } \\
\text { in median } \\
\text { water year } \\
\text { (in million } \\
\quad \text { kwh) }\end{array}$ \\
\hline $\begin{array}{l}\text { Anderson Raneh } \\
\text { Boise Diversion. } \\
\text { Barber Diversion } \\
\text { Swan Falls } \\
\text { C. J. Strike } \\
\text { Black Canyon }\end{array}$ & $\begin{array}{r}27,000 \\
1,500 \\
1,050 \\
11,325 \\
90,000 \\
28,000\end{array}$ & $\begin{array}{r}121 \\
5.3 \\
733.8 \\
734.9\end{array}$ \\
\hline Total. & $\mathbf{3} 138,875$ & 1,068 \\
\hline
\end{tabular}

1 Installed capacity for generation of firm power is about $5,500 \mathrm{kw}$.

Installed capacity for generation of firm power is about $7,500 \mathrm{kw}$.

Total capacity for generation of firm power is about 114,300 $\mathrm{kw}$.

\section{WATER UTILTZATTON}

Irrigation exceeds all other uses of water in the Boise Valley (fig. 5; table 5). The source of most irrigation water is the Boise River, but a substantial amount of ground water also is used. Farm and rural domestic water supplies are almost exclusively from wells, and public supplies for all incorporated towns in the Boise Valley, Snake River valley, and Mountain Home plateau are ground water.

TABLE 5.-Utilization of water in the Boise Valley and Mountain Home plateau, 1953

\begin{tabular}{|c|c|c|}
\hline \multirow{2}{*}{ Type of use } & \multicolumn{2}{|c|}{ Acre-feet per year } \\
\hline & $\begin{array}{c}\text { Surface } \\
\text { water }\end{array}$ & $\begin{array}{c}\text { Ground } \\
\text { water }\end{array}$ \\
\hline 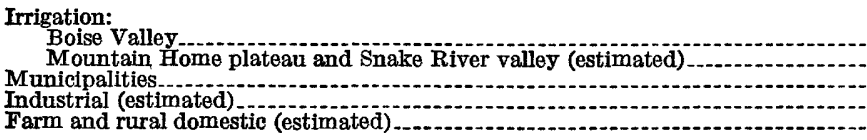 & \begin{tabular}{c}
$1,481,000$ \\
$25,000 \pm$ \\
\hdashline$<5,000$ \\
\end{tabular} & $\begin{array}{c}132,000 \\
1,000- \\
12,000 \\
2,000 \\
4,000\end{array}$ \\
\hline Total & $1,511,000$ & 151,000 . \\
\hline
\end{tabular}

SURFACE WATER

The average yearly surface-water yield from the Boise River basin above Boise Diversion Dam during the base period was about 1,760,000 

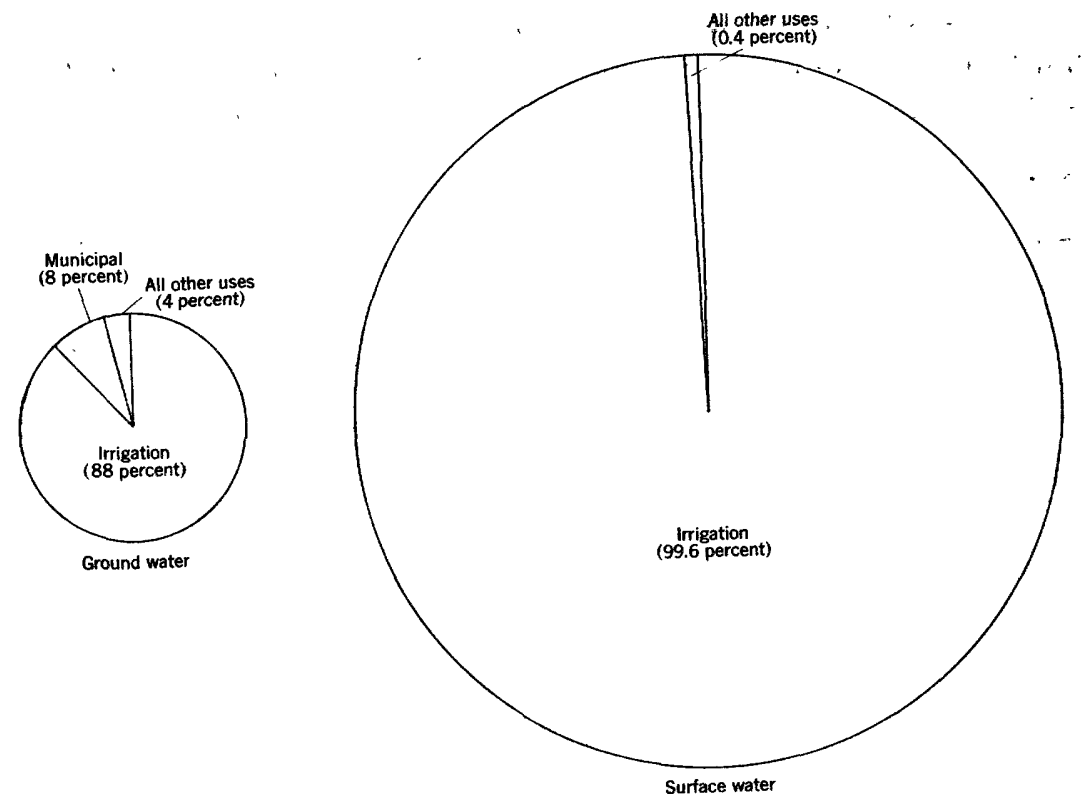

FIGURE 5.-Utilization of water in the Boise Valley, Idaho.

acre-feet (table 6). The greatest recorded runoff was $3,488,900$ acre-feet in 1943, and the smallest was 833,400 in 1924 .

The average yearly volume of irrigation diversions from the Boise River above Notus is about 1,481,000 acre-feet. According to records of the watermaster and unpublished computations by the Bureau of Reclamation, the average volume of diversions of live water from the Boise Diversion Dam during the base period was about $1,280,000$ acre-feet per year. The term "live water" designates natural flow in a stream. The live water and the return flow together make up the surface water that is available. Thus, about 200,000 acre-feet of the total that was diverted directly from the river above Notus is made up from return flow.

Probably the total of all nonirrigation applications of surface water, except for power generation, is less than 5,000 acre-feet of water per year. That demand is exceeded by ungaged contributions of small streams tributary to the Boise River. Hence this requirement is not treated here as a draft on the yield of the river at Boise Diversion Dam.

The yearly surface-water yield of streams on the Mountain Home Plateau is not known and records of the area that is irrigated from them are poor. The irrigated area is said to be about 10,000 acres, and the supply of surface water is not adequate for late-season demands (U. S. Bur. Reclamation, 1950b). The amount of surface water used for irrigation probably does not exceed 25,000 acre-feet a year and may be 
less. A small but unknown amount of surface water is used for irrigation in the valley of the Snake River. Little or no surface water is used for purposes other than irrigation on the plateau or in the valley.

TABLE 6.-Average yearly disposition of Boise River water, 1931-50, in acre-feet per calendar year

[Datafrom U. S. Geological-Survey,water-supply, papers and records of Boise Project Board of Control]

\begin{tabular}{|c|c|c|c|c|c|c|}
\hline Year & $\begin{array}{c}\text { Natural } \\
\text { discharge } \\
\text { at Boise } \\
\text { diversion } \\
\text { dam 1 }\end{array}$ & $\begin{array}{c}\text { Diversions } \\
\text { between } \\
\text { Dowling } \\
\text { Ranch and } \\
\text { Notus }^{2}\end{array}$ & $\begin{array}{c}\text { Undiverted } \\
\text { residual } \\
\text { natural } \\
\text { flow } 3\end{array}$ & $\begin{array}{c}\text { Observed } \\
\text { residual } \\
\text { discharge } \\
\text { past } \\
\text { Notus 4 }\end{array}$ & $\begin{array}{l}\text { Return- } \\
\text { flow (gain) } \\
\text { between } \\
\text { diversion } \\
\text { dam and } \\
\text { Notus }\end{array}$ & $\begin{array}{l}\text { Net deple- } \\
\text { tion above } \\
\text { Notus }\end{array}$ \\
\hline $\begin{array}{l}1931 \\
1932 \\
1934 \\
1935 \\
1936 \\
1938 \\
1939 \\
1940 \\
1941 \\
1944 \\
1946\end{array}$ & $\begin{array}{r}905,700 \\
1,971,000 \\
1,645,000 \\
1,062,000 \\
\mathbf{1}, 547,000 \\
\mathbf{1}, 979,300 \\
\mathbf{1}, \mathbf{1 7 8 , 8 0 0} \\
2,550,400 \\
1,404,000 \\
1,576,800 \\
1,406,000 \\
1,686,000 \\
3,488,900 \\
1,287,900 \\
\mathbf{1}, 611,200 \\
2,351,600 \\
1,881,400 \\
1,737,200 \\
1,846,600 \\
2,080,000\end{array}$ & $\begin{array}{l}963,051 \\
1,587,038 \\
1,507,552 \\
1,160,021 \\
1,441,016 \\
1,459,082 \\
1,286,440 \\
1,612,190 \\
1,407,865 \\
1,392,232 \\
1,482,342 \\
1,489,400 \\
1,675,619 \\
1,377,785 \\
1,493,694 \\
1,613,613 \\
1,670,991 \\
1,524,482 \\
1,709,066 \\
1,764,186\end{array}$ & $\begin{array}{r}-57,351 \\
383,962 \\
137,448 \\
-98,021 \\
105,984 \\
520,218 \\
-107,640 \\
938,210 \\
-3,865 \\
184,568 \\
-76,342 \\
196,600 \\
1,813,281 \\
-89,885 \\
117,506 \\
737,987 \\
210,409 \\
212,718 \\
137,534 \\
315,814\end{array}$ & $\begin{array}{r}180,000 \\
816,000 \\
515,000 \\
192,700 \\
424,900 \\
920,000 \\
202,300 \\
1,467,000 \\
358,700 \\
581,200 \\
365,200 \\
656,100 \\
2,253,000 \\
274,600 \\
625,200 \\
1,220,000 \\
688,200 \\
642,500 \\
683,700 \\
944,300\end{array}$ & $\begin{array}{l}237,351 \\
432,038 \\
377,552 \\
290,721 \\
318,916 \\
399,782 \\
309,940 \\
528,790 \\
362,565 \\
396,632 \\
441,542 \\
459,500 \\
439,719 \\
364,485 \\
507,694 \\
482,013 \\
477,791 \\
429,782 \\
546,166 \\
628,486\end{array}$ & $\begin{array}{r}725,700 \\
1,155,000 \\
1,130,000 \\
869,300 \\
1,122,100 \\
1,059,300 \\
976,500 \\
1,083,400 \\
1,045,300 \\
995,600 \\
1,040,800 \\
1,029,900 \\
1,235,900 \\
1,093,300 \\
986,000 \\
1,131,600 \\
1,193,200 \\
1,094,700 \\
1,162,900 \\
1,135,700\end{array}$ \\
\hline Total. & $35,196,800$ & $29,617,665$ & $5,579,135$ & $14,010,600$ & $8,431,465$ & $21,186,200$ \\
\hline $\begin{array}{l}\text { Mean } \\
\text { Rounded mean }\end{array}$ & $\begin{array}{l}1,759,840 \\
1,760,000\end{array}$ & $\begin{array}{l}1,480,883 \\
1,481,000\end{array}$ & $\begin{array}{l}278,957 \\
279,000\end{array}$ & $\begin{array}{l}700,530 \\
701,000\end{array}$ & $\begin{array}{l}421,573 \\
422,000\end{array}$ & $\begin{array}{l}1,059,310 \\
1,059,000\end{array}$ \\
\hline
\end{tabular}

1 Sum of discharge of Boise River at Dowling Ranch near Arrowrock, and of Moore Creek near Arrowrock.

2 Includes winter diversions in New York Canal.

Negative sign indicates no undiverted residual natural flow. The given amount of water was obtained by diversion of return-flow water.

+ Residual natural flow, plus residual return flow from surface drains, plus ground-water discharge into river channel.

\section{GROUND WATER}

The amount of ground water used for irrigation far exceeds the combined volume of ground water used for all other purposes (fig. 5; table 5). The estimated average pumpage and artesian flow from irrigation and drainage wells of record in the Boise Valley is 128,000 acre-feet a year. Additional unrecorded wells, chiefly on the north side of the river, probably discharge a few thousand acre-feet, and the assumed aggregate discharge from drainage and irrigation wells is 130,000 to 135,000 acre-feet. Practically all the discharged water is salvaged for irrigation. Pumping for irrigation generally is restricted to a period of about 180 days and is largely within a period of about 120 days.

About 10,000 acres of land in the Boise Valley is irrigated wholly with water from wells. Assuming a well-head delivery requirement of 4.0 acre-feet per acre, pumpage for this land would be 40,000 acre-feet. The remaining 92,000 acre-feet of ground water supplements surface water on an undetermined acreage. For the purposes of this report 
it is assumed that the supplemental ground water serves an equivalent area of 23,000 acres with 4.0 acre-feet of water per acre and that the total equivalent and actual area served is 33,000 acres. The principal area of ground-water pumping is in a north-south belt through the central part of the valley (pl. 3 ). There are many private irrigation wells on high lands adjacent to Lake Lowell, and many drainage wells in the Pioneer Irrigation District and the western part of the Nampa-Meridian Irrigation District.

A large but undetermined volume of ground water is collected in gravity drainage ditches, and much of this water is salvaged for irrigation. The aggregate yield of the drains greatly exceeds that of wells.

The municipal demand on ground water varies somewhat with the seasons, being greatest in the summer. The amount pumped yearly is about 12,000 acre-feet, chiefly in the Boise Valley. Figures for consumptive use are not available but it seems likely that about 50 percent of the water is discharged as sewage effluent to the Boise River and to the ground through cesspools.

On the Mountain Home plateau only a few wells furnish water for irrigation. The amount of water pumped probably does not exceed 700 acre-feet a year (rounded to 1,000). Little or no ground water is pumped for irrigation in the Snake River valley. Pumpage for municipal and domestic supply is insignificant on the plateau and in the valley.

\section{PHYSICAI SUBDIVISIONS AND LANDFORMS}

The area in which the alternate plan would operate includes three principal physical subdivisions: the valley of the Snake River, the Mountain Home plateau, and the Boise Valley (pl. 1). Contrasting aspects of the water situation in these subdivisions correlate directly with their different landforms and geologic features. These aspects control or influence precipitation and surface runoff, as well as groundwater recharge, storage, and movement.

\section{VALMEY OF THE SNAKE RIVER}

Along the south side of the Mountain Home plateau the Snake River flows northwestward in a canyon as much as 700 feet deep (see pl. 1). Downstream the canyon diminishes in depth until at the mouth of the Boise River, about 50 miles below Swan Falls, it passes into a broad channel only about 100 feet below the general level of adjacent plains. The altitude of the floor of the Snake River canyon at Swan Falls is 2,287 feet; nearby, the north wall of the canyon rises to an altitude of about 3,000 feet. At the confluence of the Snake and Boise Rivers the altitude along the river is about 2,200 feet and of the adjacent. plain, 2,300 feet. 
Cliffs, bluffs, and steep slopes along parts of the Snake River are formed by several hundred feet of interbedded alluvial and lake sediments and volcanic rocks. Extensive landslide blocks contain materials of both types. Much of the narrow floor of the valley is covered by Recent alluvial sediments.

\section{MOUNTANN hOME PLATHAU}

The Mountain Home plateau is a rolling upland plain, much of which is mantled by windblown sediments. These and other sediments subdue the comparatively rough topography and local sharp relief on the volcanic rocks which form most of the plateau. The general surface of the plateau slopes northwestward and southwestward from an altitude of 3,200 feet near Mountain Home to an altitude of 2,700 feet near Kuna and Melba. The highest altitude on the plateau, on the top of a volcanic cone about 5 miles northwest of Mountain Home, is somewhat more than 3,800 feet.

The basalt flows, which are exposed in many parts of the plateau, range in character from smoothly rolling to rough and broken. A few extinct volcanic cones rise above the general surface of the plateau, which contains also several volcanic explosion pits. Near the mountains, along the northeastern border, alluvial sand and gravel overlie volcanic rocks adjacent to foothills and along intermittent watercourses. In the northern part of the plateau there are extensive, thick accumulations of compacted, poorly sorted gravel which were deposited on a high alluvial plain in a pre-Recent stage of geologic history.

\section{BOISE VALLEY}

The Boise Valley includes the lowland, terraces, and adjacent foothill slopes along the western part of the Boise River, west of Boise Diversion Dam. Above the dam the river and its tributaries occupy narrow mountain canyons. The headwater reaches of small downstream tributaries also are in mountainous terrain.

The Boise Valley lowland is a broad alluvial plain having low relief, adjacent to the Boise River. Southward, terraces form a transition belt of low scarps and benches that rise steplike to the level of the Mountain Home plateau. On the north and east the valley is bounded by foothills. On the west it merges with the valley of the Snake River.

Relief within the Boise Valley is generally low. The altitude of the lowland plain in the vicinity of Boise is about 2,650 to 2,700 feet above sea level. The surface of the Gowen Terrace at Gowen Field, a mile and a half south of the Boise city limit, is at an altitude of about 2,800 feet. In the vicinity of Nampa and Caldwell local basalt ridges rise as much as 100 to 400 feet above the bottom land. The altitude of the valley floor at its western edge is slightly less than 2,200 feet. 


\section{GEOLOGIC FACTORS IN THE OCCURRENCE OF WATER}

The water aspects of the principal physical subdivisions and landform components of the area differ greatly because the materials forming the physical features range from highly permeable to nearly impermeable. Within each subdivision, also, the earth materials differ markedly in their capacities to accept recharge and to yield ground water, and in their susceptibility to drainage by ground-water pumping. The geologic factors thus are a critical element in the environment of the alternate plan, and these factors would largely determine the feasibility of pumping exchange irrigation water at places where pumping would produce adequate drainage benefits. The principal geologic formations in the area are identified and described briefly in table 7 , which contains formation names that are in common use and a working nomenclature for unnamed formations. The surface distribution of the units is shown on the geologic map (pl. 2). Some formations do not crop out at the surface in the area shown on the map but are present at depth.

Beneath the entire area, from the mountains north of Boise southwestward to the Owyhee Mountains, a huge basin is formed by a troughlike, impermeable floor of consolidated ancient rocks, the Idaho and Owyhee batholiths (table 7) and associated older rocks. Within this trough is a great thickness of Tertiary stream- and lakedeposited sediments (Payette formation) and volcanic rocks (socalled Owyhee rhyolite of Kirkham (1931c) and Columbia River basalt). These rocks have generally low permeability but form a deep regional artesian ground-water reservoir in which the water-bearing beds are at depths of hundreds to perhaps thousands of feet. Resting on these materials is a younger group of sediments, the Idaho formation, which is quite varied in its water-bearing properties but is somewhat more permeable than the older sediments. The Idaho formation, consisting chiefly of clay, silt, and sand, is a source of moderately deep artesian water in the Boise and Snake River valleys. On the ancient land surface formed by the Idaho formation, streams spread a thick sheet of rather permeable terrace gravel. Lava flows formed the Snake River basalt, which rests on the lower part of the gravel at some places and is covered by the upper part of the gravel at other places. Basalt accumulated chiefly on the Mountain Home plateau and in the south-central part of the Boise Valley, only a few sheets extending to the southern edge of the eastern part of the valley. The Snake River then cut a deep canyon through the basalt and sediments, forming the present course of the Snake River. Meanwhile the Boise Valley was formed by alternate stream erosion and deposition, which formed terraces underlain by permeable younger terrace gravel, and bottom land occupied by highly permeable Recent 
alluvium. Recent local basalt flows are interbedded with terrace gravel at a few places. Thus the younger water-bearing deposits in the Boise Valley occupy a partly closed basin that was eroded in the older terrace gravel and Idaho formation.

The resulting water situation in the Boise Valley is distinctive and in complete contrast to that in the rest of the area. Most of the earth materials within a few hundred feet of the surface are quite porous and permeable. They accept recharge readily and can store and yield moderate to large amounts of water. The valley is enclosed on the north and east by mountains, and on the south by a plateau. On the west the valleys of the Boise and Snake Rivers intersect at grade. Thus the Boise Valley has a closed plumbing system, somewhat leaky at depth, but with free-running outlets westward only at the surface and at shallow depth. Under the old natural water conditions in the valley, the water table was at shallow depth in the bottom lands and probably not more than 100 to 200 feet deep beneath the terraces and lowland slopes. Under the new conditions, created by surface-water diversion and irrigation, there has been a large amount of artificial ground-water recharge; much water that formerly was discharged in the river now is discharged westward through the ground. The earth materials to the west, however, are generally less permeable than those to the east. Hence, groundwater levels to the east have risen high to produce enough hydraulic gradient to move the water westward.

The water situation in the Mountain Home plateau reflects directly the special geologic fact that the plateau, built up largely by basalt flows, remains but little changed from its condition when the volcanic eruptions ceased. The basalt is overlain in large areas by windblown sand and silt, and locally by gravel deposits. All these materials are sufficiently permeable to accept readily most of the water that is made available by the scanty rainfall. Recharge does not build the ground water to high levels because the water drains out rapidly at the lower end of the aquifers to the valley of the Snake River, which functions as a ground-water drain. The deeply incised valley literally cuts off the lower end of the plumbing system of the plateau, leaving it open. Thus, in most of the plateau water can be obtained from wells only at considerable depth. Moreover, much of the volcanic rock and sediment has only moderate to low permeability and does not yield water copiously to wells. Toward the edge of the Snake River valley, however, where ground water from the east and northeast is being discharged naturally, substantial supplies of ground water can be developed at some places from relatively shallow depths. 


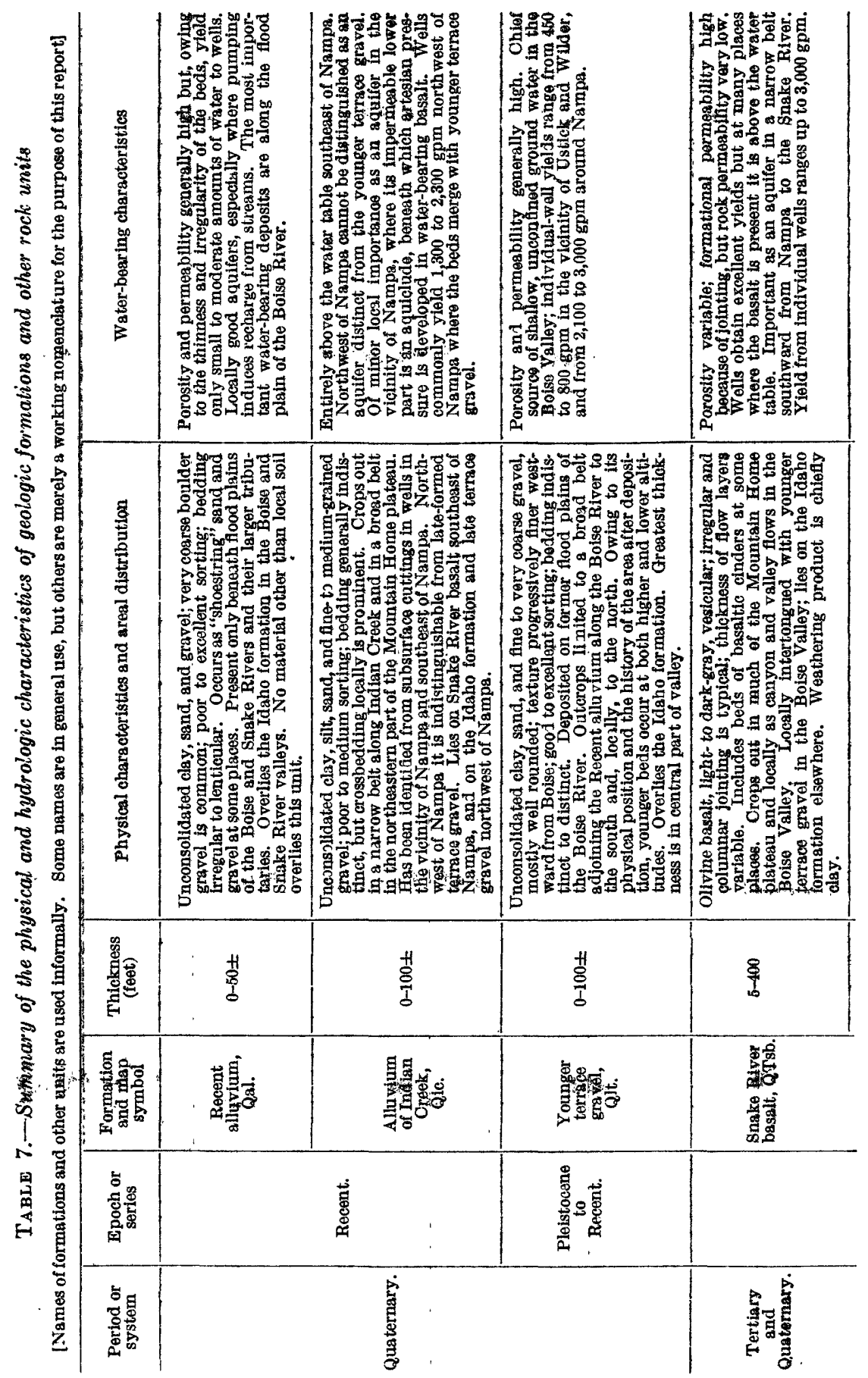




\begin{tabular}{|c|c|c|c|c|}
\hline & 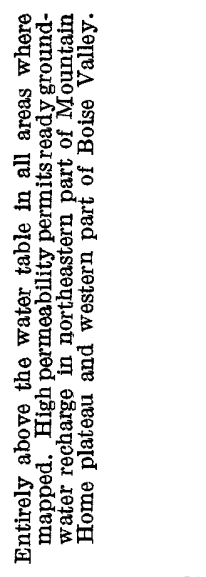 & 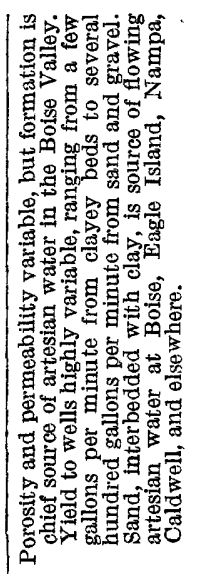 & 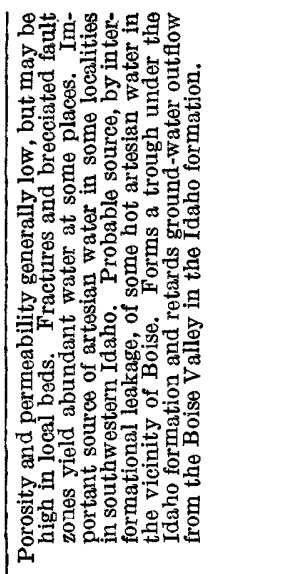 & 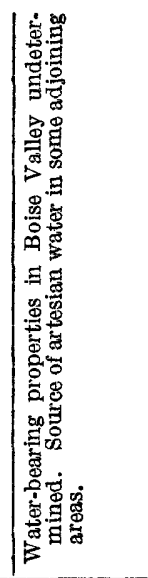 \\
\hline 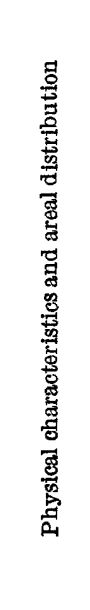 & 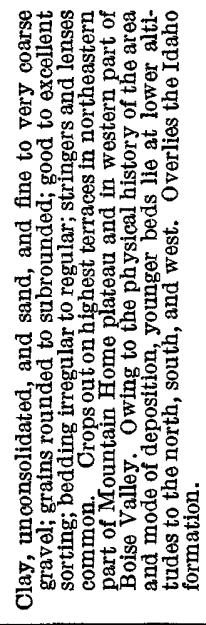 & 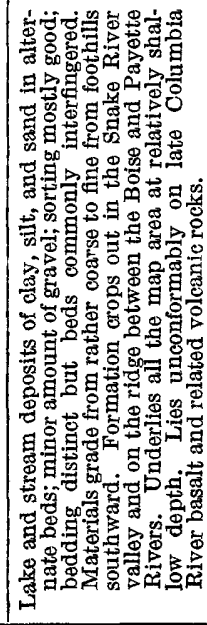 & 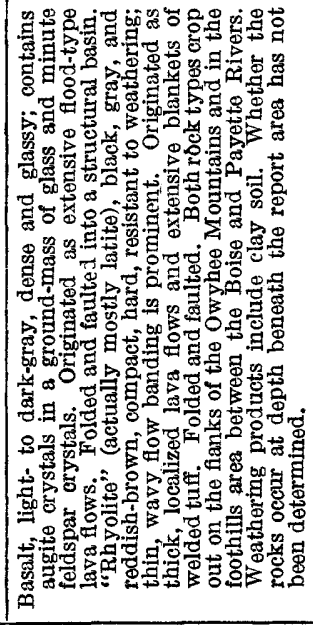 & 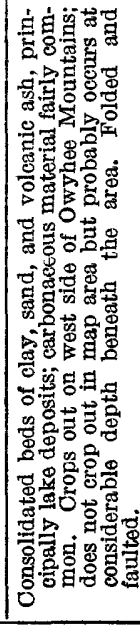 \\
\hline 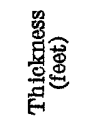 & $\underset{\substack{\mathrm{S} \\
\text { H }}}{H}$ & 兽兽 & 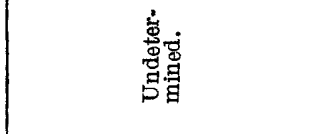 & 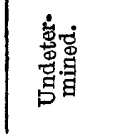 \\
\hline 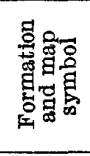 & 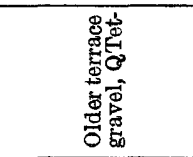 & 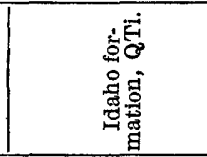 & 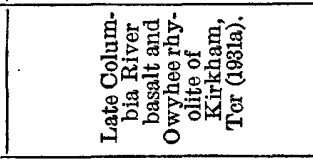 & 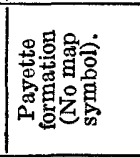 \\
\hline 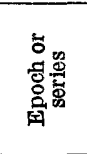 & 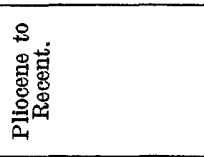 & 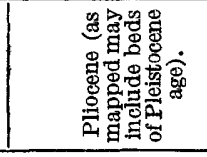 & 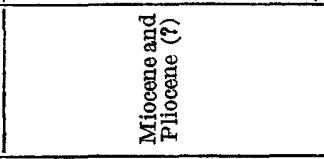 & \\
\hline 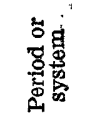 & \multicolumn{2}{|l|}{ 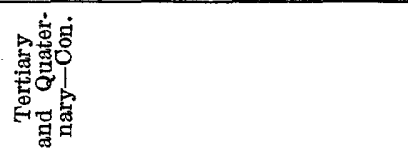 } & \multicolumn{2}{|l|}{$\begin{array}{l}\text { 宫 } \\
\text { 总 } \\
\text { E. }\end{array}$} \\
\hline
\end{tabular}




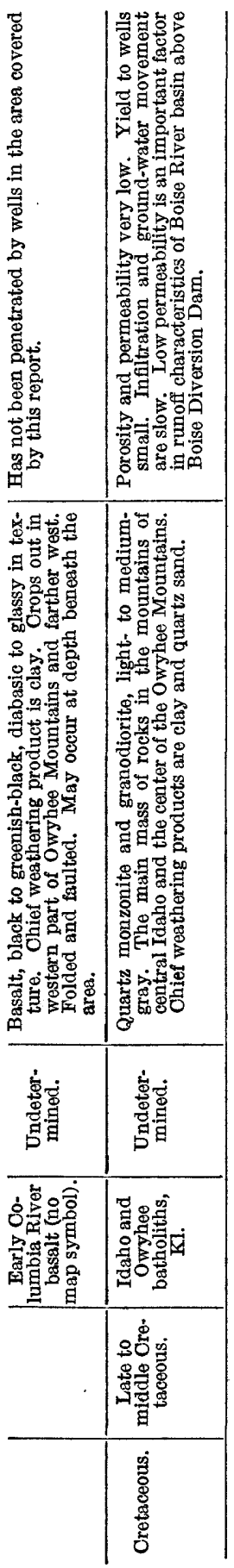




\section{CIIMATIC FACTORS}

\section{PRECIPITATION}

Precipitation in the report area is highly seasonal, being heaviest in winter and lightest in summer (table 8). The maximum precipitation rexorded at the Boise weather station in a single year since 1900 was 18.10 inches, in 1912 ; the minimum was 7.43 inches, in 1949. The maximum precipitation in a 24-hour period was 1.51 inches, in May 1942, and the maximum for a calendar month was 5.39 inches, in March 1904.

Inasmuch as precipitation is the original source of essentially all the water supply, the total volume of precipitation is important. The volume is estimated here on the basis of records from 9 stations of the U. S. Weather Bureau and 17 upland stations of the U. S. Forest Service. Records from these stations are reasonably adequate for present purposes. The average annual precipitation at Weather Bureau stations during the period of record (table 8) differs only slightly from that of the base period (table 9). The mean values in table 9 were used for the present report, thus reducing the preeipitation and streamflow records to a common base period.

The volume of precipitation was computed on the basis of records from 26 stations, for which the mean annual value was adjusted to the base period (table 10). Mean values for stations at Lowman and Anderson Ranch Dam, for which only short periods of continuous record are available, were adjusted to the base period by double-mass analysis (fig. 6). Other adjustments were made by direct ratio with corresponding periods of record for the seven control stations included in table 10. The adjusted precipitation values were used to construct the isohyetal map (fig. 7), from which the area-volumes of precipitation in table 11 were computed.

TABLE 8.-Average monthly precipitation, in inches, at stations in Ada, Canyon, and Elmore Counties, Idaho

[From published records of the U. S. Weather Bureau]

\begin{tabular}{|c|c|c|c|c|c|c|c|c|c|c|c|c|c|c|}
\hline Station & Jàn. & Feb. & Mar. & Apr. & May & June & July & Aug. & Sept. & Oet. & Nov. & Dec. & $\begin{array}{c}\text { A ver- } \\
\text { age } \\
\text { annual }\end{array}$ & $\begin{array}{l}\text { Years } \\
\text { of } \\
\text { record }\end{array}$ \\
\hline $\begin{array}{l}\text { Arrowrock Dam } \\
\text { Boise } \\
\text { Caldwell } \\
\text { Glenns Ferry } \\
\text { Meridian } \\
\text { Mountain Home. } \\
\text { Nampa }\end{array}$ & $\begin{array}{l}2.64 \\
1.33 \\
1.26 \\
1.14 \\
1.42 \\
1.18 \\
1.06\end{array}$ & $\begin{array}{r}2.39 \\
1.35 \\
1.14 \\
.97 \\
1.25 \\
1.11 \\
.85\end{array}$ & $\begin{array}{r}1.93 \\
1.34 \\
1.04 \\
.69 \\
1.21 \\
1.01 \\
.84\end{array}$ & $\begin{array}{r}1.59 \\
1.10 \\
.94 \\
.76 \\
1.11 \\
.94 \\
.98\end{array}$ & $\begin{array}{r}1.25 \\
1.09 \\
.98 \\
.86 \\
1.17 \\
.90 \\
1.11\end{array}$ & $\begin{array}{l}0.96 \\
.84 \\
.77 \\
.61 \\
.87 \\
.70 \\
.81\end{array}$ & $\begin{array}{r}0.40 \\
.18 \\
.33 \\
.31 \\
.27 \\
.37 \\
.16\end{array}$ & $\begin{array}{l}0.26 \\
.21 \\
.22 \\
.12 \\
.20 \\
.17 \\
.20\end{array}$ & $\begin{array}{l}0.53 \\
.46 \\
.47 \\
.31 \\
.51 \\
.48 \\
.30\end{array}$ & $\begin{array}{r}1.24 \\
.94 \\
.78 \\
.59 \\
.98 \\
.90 \\
.89\end{array}$ & $\begin{array}{l}2.54 \\
1.35 \\
1.14 \\
1.23 \\
1.35 \\
1.15 \\
1.03\end{array}$ & $\begin{array}{l}2.57 \\
1.29 \\
1.14 \\
.99 \\
1.34 \\
1.11 \\
1.32\end{array}$ & $\begin{array}{r}18.30 \\
11.48 \\
10.21 \\
8.58 \\
11.68 \\
10.02 \\
9.55\end{array}$ & $\begin{array}{r}1912-45 \\
1921-50 \\
1905-45 \\
1918-45 \\
1911-45 \\
11912-52 \\
11894-52\end{array}$ \\
\hline
\end{tabular}

\footnotetext{
1 Records are intermittent.
} 
TABLi 9.-Precipitation, in inches, at weather stations in or near the Boise River basin, $1931-50$

[From published records co the U. S. Weather Bureau]

\begin{tabular}{|c|c|c|c|c|c|c|c|c|c|}
\hline Year & $\begin{array}{c}\text { Arrow- } \\
\text { rock } \\
\text { Dam }\end{array}$ & Atlanta & Boise & $\begin{array}{l}\text { Cald- } \\
\text { well }\end{array}$ & $\begin{array}{l}\text { Em- } \\
\text { mett }\end{array}$ & $\begin{array}{c}\text { Idaho } \\
\text { City }\end{array}$ & $\begin{array}{l}\text { Moun- } \\
\text { tain } \\
\text { Home }\end{array}$ & $\begin{array}{l}\text { Low- } \\
\text { man }\end{array}$ & $\begin{array}{l}\text { Ander- } \\
\text { son } \\
\text { Ranch } \\
\text { Dam }\end{array}$ \\
\hline $\begin{array}{l}1931 \\
1932 \\
1933 \\
1934 \\
1935 \\
1936 \\
1937 \\
1938 \\
1939 \\
1940 \\
1941 \\
1942 \\
1943 \\
1944 \\
1945 \\
1946 \\
1947 \\
1948 \\
1949 \\
1950\end{array}$ & $\begin{array}{l}14.17 \\
20.01 \\
14.00 \\
15.60 \\
10.67 \\
17.29 \\
19.92 \\
23.06 \\
12.25 \\
22.46 \\
20.91 \\
23.32 \\
16.51 \\
15.11 \\
24.81 \\
19.14 \\
15.96 \\
20.86 \\
15.79 \\
22.91\end{array}$ & $\begin{array}{l}17.65 \\
27.44 \\
18.81 \\
23.40 \\
15.76 \\
28.11 \\
19.21 \\
25.83 \\
19.15 \\
29.47 \\
30.76 \\
29.88 \\
28.76 \\
-33.46 \\
32.16 \\
23.66 \\
32.10 \\
23.06 \\
38.06\end{array}$ & $\begin{array}{r}9.41 \\
13.09 \\
7.95 \\
10.62 \\
9.09 \\
9.79 \\
12.60 \\
16.40 \\
8.08 \\
13.77 \\
13.81 \\
14.48 \\
9.92 \\
10.45 \\
13.44 \\
9.86 \\
10.08 \\
11.91 \\
7.43 \\
13.99\end{array}$ & $\begin{array}{r}7.26 \\
10.92 \\
6.93 \\
8.12 \\
7.55 \\
8.25 \\
11.82 \\
12.41 \\
6.30 \\
15.02 \\
13.54 \\
14.65 \\
11.32 \\
9.39 \\
13.18 \\
7.49 \\
9.03 \\
12.76 \\
5.13 \\
12.45\end{array}$ & $\begin{array}{r}7.28 \\
10.41 \\
6.69 \\
8.93 \\
6.26 \\
8.54 \\
13.15 \\
14.49 \\
6.50 \\
18.51 \\
15.66 \\
15.57 \\
11.60 \\
11.88 \\
14.99 \\
11.68 \\
11.03 \\
15.29 \\
8.89 \\
16.64\end{array}$ & $\begin{array}{l}18.95 \\
22.33 \\
18.64 \\
19.51 \\
12.54 \\
22.95 \\
26.37 \\
26.79 \\
14.66 \\
26.58 \\
21.75 \\
26.71 \\
21.93 \\
18.50 \\
27.87 \\
22.47 \\
20.37 \\
26.22 \\
18.78 \\
26.76\end{array}$ & $\begin{array}{r}5.49 \\
12.14 \\
6.86 \\
6.37 \\
6.49 \\
7.50 \\
7.94 \\
11.72 \\
4.90 \\
11.59 \\
12.36 \\
10.49 \\
8.96 \\
9.43 \\
12.77 \\
12.07 \\
6.21 \\
6.48 \\
5.99 \\
10.94\end{array}$ & \begin{tabular}{|c|} 
\\
\end{tabular} & $\begin{array}{r} \\
\end{array}$ \\
\hline Total.......... & $\begin{array}{r}364.75 \\
18.24\end{array}$ & $\begin{array}{r}496.73 \\
26.14\end{array}$ & $\begin{array}{r}226.17 \\
11.31\end{array}$ & $\begin{array}{r}203.52 \\
10.18\end{array}$ & $\begin{array}{r}233.99 \\
11.70\end{array}$ & $\begin{array}{r}440.68 \\
22.03\end{array}$ & $\begin{array}{r}176.70 \\
8.84\end{array}$ & 122.00 & 117.81 \\
\hline
\end{tabular}

1 Mean adjusted to base period by double-mass analysis.

TABLE 10.-Precipitation at stations used for construction of isohyetal map of Baise River basin

[Figures in columns for "years of record" and "mean annual precipitation" are as given in the Climatological Records of the U. S. Weather Bureau and may represent fragmentary years of record and adjusted normal precipitation. Those stations for which the period of record is not known could not be adjusted to the base period and the published mean annual values were used]

\begin{tabular}{|c|c|c|c|c|c|}
\hline Station & $\underset{\text { (feet) }}{\text { Altitude }}$ & $\begin{array}{l}\text { Period of } \\
\text { record }\end{array}$ & $\begin{array}{l}\text { Years of } \\
\text { record }\end{array}$ & $\begin{array}{l}\text { Mean an- } \\
\text { nual pre- } \\
\text { cipitation } \\
\text { (inches) }\end{array}$ & $\begin{array}{l}\text { Mean ad- } \\
\text { justed to } \\
\text { period } \\
1931-50 \\
\text { (inches) }\end{array}$ \\
\hline $\begin{array}{l}\text { Anderson Ranch Dam } \\
\text { Arrowrock Dam } 1 \\
\text { Atlanta } 1 \\
\text { Atlanta Summit. } \\
\text { Bogus Creek }\end{array}$ & $\begin{array}{l}3,882 \\
3,238 \\
6,000 \\
7,590 \\
4,200\end{array}$ & $\begin{array}{l}1942-53 \\
\text { To } 1953 \ldots- \\
\text { do } \\
\text { (?) } \\
1909-30\end{array}$ & $\begin{array}{r}12 \\
42 \\
37 \\
3 \\
22\end{array}$ & $\begin{array}{l}18.98 \\
18.30 \\
24.51 \\
46.82 \\
24.91\end{array}$ & $\begin{array}{r}17.81 \\
18.24 \\
26.14 \\
23.66\end{array}$ \\
\hline $\begin{array}{l}\text { Boise } 1 \\
\text { Boise King } \\
\text { Caldwell 1 } \\
\text { Deadwood Dam } \\
\text { Emmett }{ }^{1}\end{array}$ & $\begin{array}{l}2,842 \\
4,000 \\
2,372 \\
5,375 \\
2,500\end{array}$ & \begin{tabular}{l} 
To $1953 \ldots$ \\
$1913-20 .-$ \\
To $1953 \ldots$ \\
\hdashline do \\
do
\end{tabular} & $\begin{array}{r}89 \\
7 \\
49 \\
24 \\
47\end{array}$ & $\begin{array}{l}11.48 \\
25.75 \\
10.21 \\
32.87 \\
11.45\end{array}$ & $\begin{array}{l}11.31 \\
23.17 \\
10.18 \\
32.87 \\
11.70\end{array}$ \\
\hline $\begin{array}{l}\text { Garden Valley } \\
\text { Idaho City } 1 \\
\text { Jackson Peak } \\
\text { Lake Lowell } \\
\text { Little Camas. }\end{array}$ & $\begin{array}{l}3,147 \\
3,940 \\
7,050 \\
2,510 \\
5,000\end{array}$ & (?) $1958 \ldots$ & $\begin{array}{r}43 \\
50 \\
4 \\
36 \\
16\end{array}$ & $\begin{array}{r}22.14 \\
21.48 \\
47.92 \\
8.43 \\
19.48\end{array}$ & $\begin{array}{r}22.14 \\
22.03 \\
8.43 \\
18.50\end{array}$ \\
\hline $\begin{array}{l}\text { Lowman } \\
\text { Meridian } \\
\text { Moore Creek Summit } \\
\text { Mountain Home }{ }^{1} \\
\text { Parma }\end{array}$ & $\begin{array}{l}3,870 \\
2,607 \\
5,990 \\
3,164 \\
2,224\end{array}$ & $\begin{array}{l}\text { To } 1953 \ldots \\
\text { (?) } \\
\text { To } 1953_{\ldots} \\
\text { do }\end{array}$ & $\begin{array}{r}44 \\
43 \\
2 \\
48 \\
31\end{array}$ & $\begin{array}{r}22.95 \\
11.68 \\
50.93 \\
10.02 \\
8.62\end{array}$ & $\begin{array}{r}22.00 \\
11.68 \\
88.84 \\
8.62\end{array}$ \\
\hline $\begin{array}{l}\text { Payette. } \\
\text { Pine } \\
\text { Sheep Hill } \\
\text { Trinity Lakes } \\
\text { Troutdale }\end{array}$ & $\begin{array}{l}2,159 \\
4,225 \\
5,000 \\
7,400 \\
4,375\end{array}$ & $\begin{array}{l}\text { do } \\
\text { do do } \\
\text { (?) } \\
\text { (?) }\end{array}$ & $\begin{array}{r}60 \\
42 \\
22 \\
4 \\
4\end{array}$ & $\begin{array}{l}10.87 \\
21.48 \\
25.43 \\
57.57 \\
23.25\end{array}$ & $\begin{array}{r}10.87 \\
21.48 \\
24.16 \\
\end{array}$ \\
\hline Viemna... & 8,800 & (?) $\ldots$ & 4 & 49.60 & - - \\
\hline
\end{tabular}

1 Control stations used for adjusting values of mean annual precipitation to the base period. (See fig. 6.) 386771-57-3 


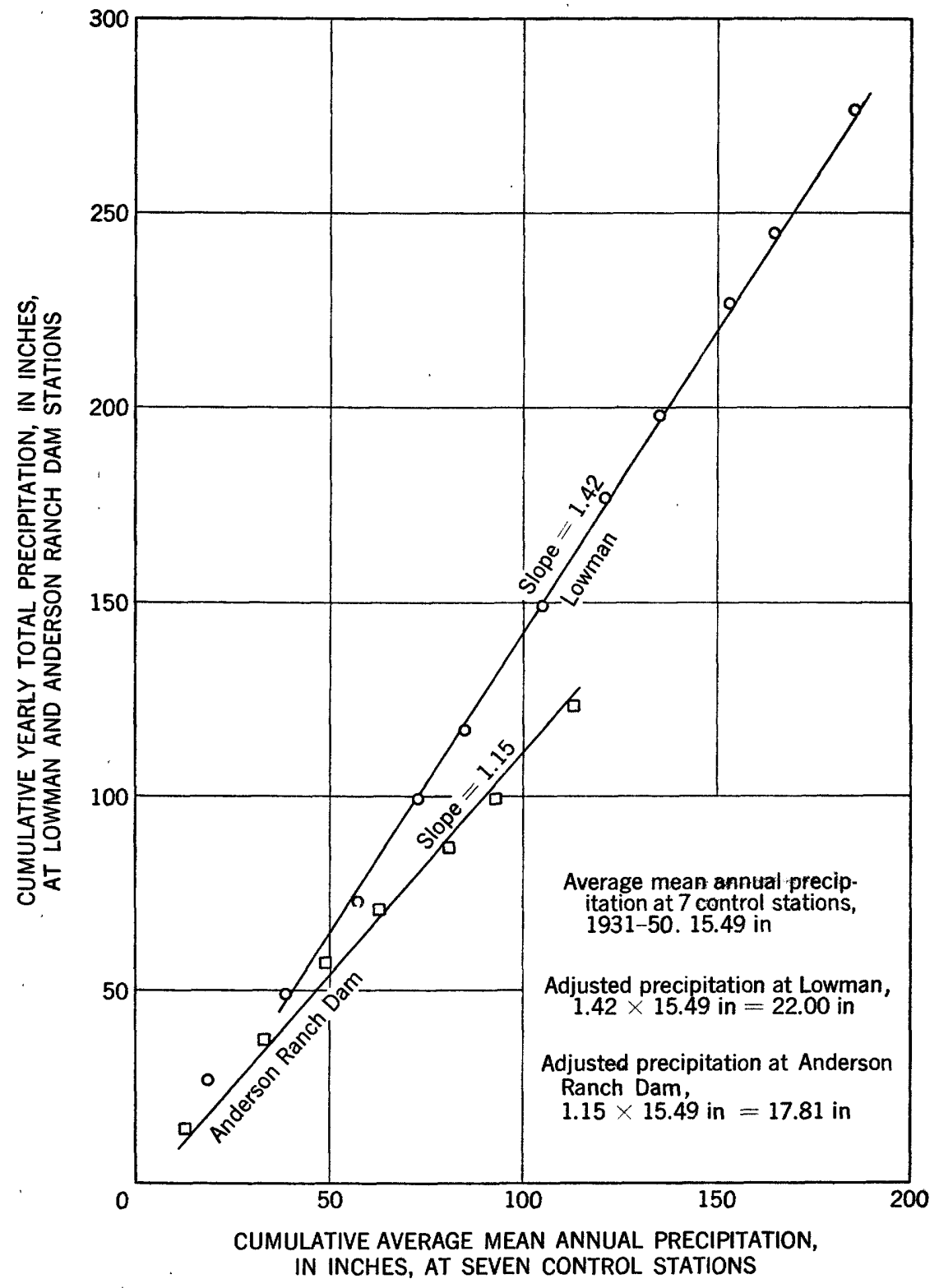

FIGURE 6.-Double mass plot for adjusting mean annual precipitation at two stations with short records.

Land areas in the lowland in the following table do not in all instances agree with those in other tables, or with published areas. Published data are unacceptable as a basis for computing recharge from precipitation because the net irrigated area in the Boise Valley substantially exceeds that reported. For example, much Boise 


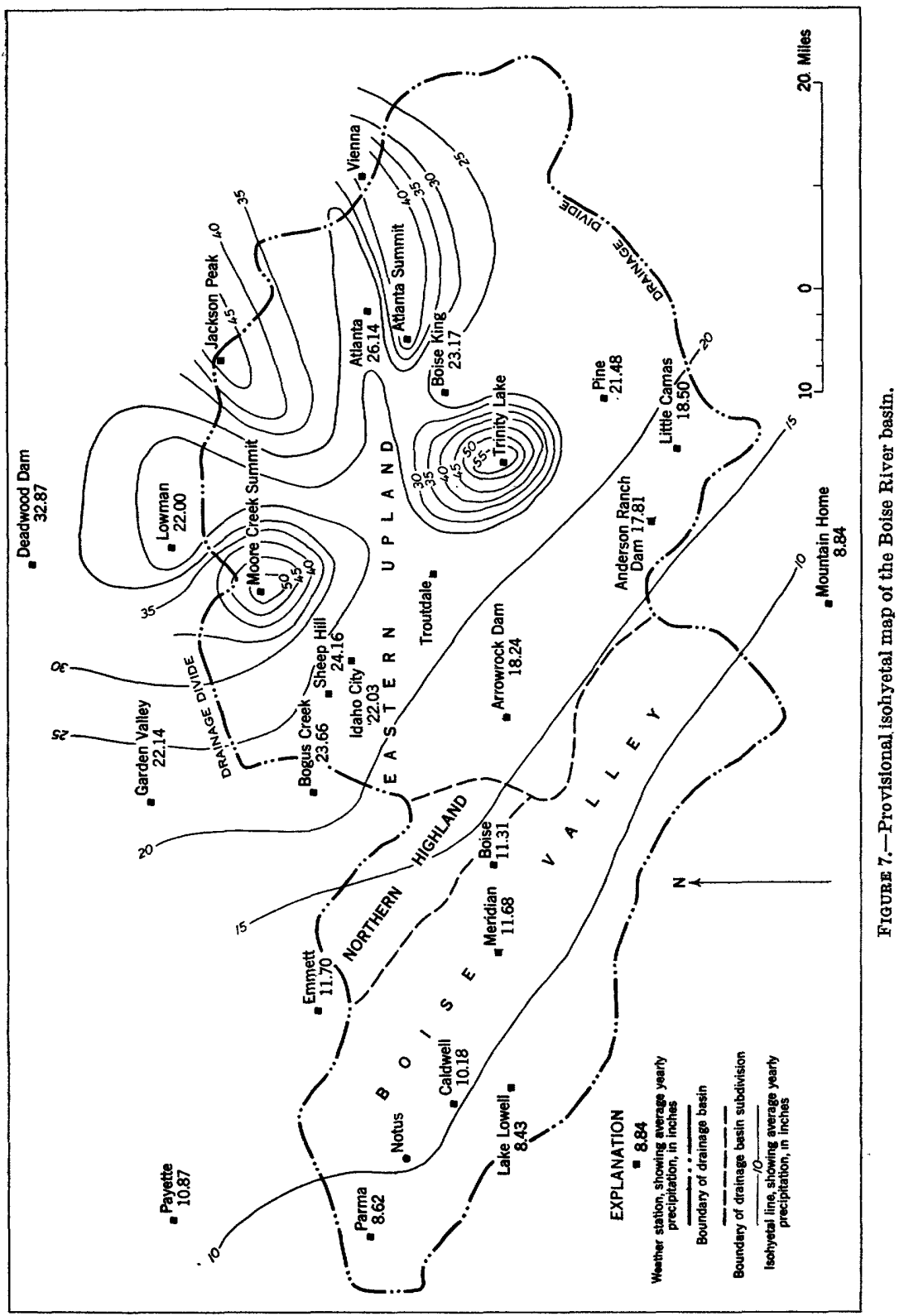


River bottom land is irrigated or subirrigated; an appreciable miscellaneous acreage also is irrigated by small cooperatives and by use of ungaged waste water and ground water. In order to reach a reasonable approximation of recharge from precipitation, gross irrigated and nonirrigated areas, so far as they could be identified, were segregated and their areas were determined by planimetric measurement, on maps.

TABLE 11.-Estimated volume of average annual precipitation on the Boise River basin

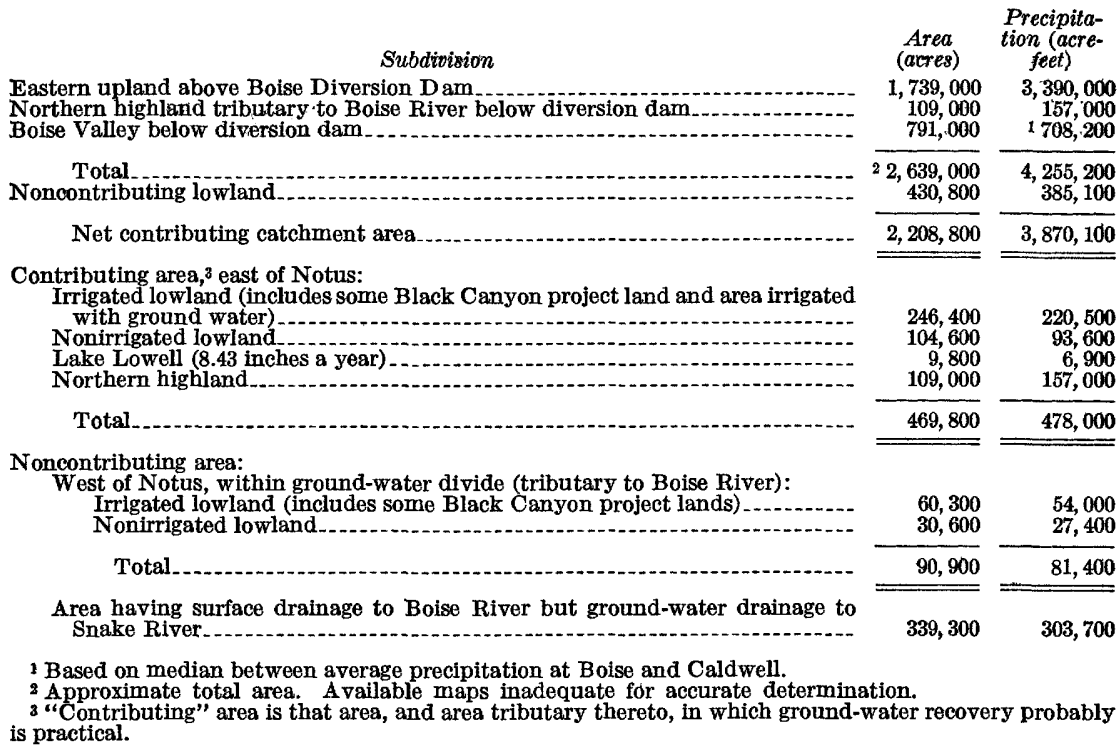

The volume of precipitation on the Mountain Home plateau can be estimated only very approximately from the inadequate data on precipitation. For the purpose of the estimate an eastern boundary was chosen arbitrarily at $115^{\circ} 30^{\prime}$ west longitude (pl. 1). The rainfallcatchment area of the plateau, including the tributary mountainous area along the northeast, is about 750,000 acres. The estimated average annual rainfall-the median of the amounts at Boise, near the north margin of the plateau, and at Mountain Home, in the southcentral part-is 10.08 inches (rounded to 10.1). The estimated volume of precipitation on the whole area is about 631,000 acre-feet.

\section{TEMPGRATURE}

The mean annual temperature at Boise is $50.8^{\circ} \mathrm{F}$. July has the highest, and January the lowest, average monthly temperature. The maximum temperature recorded at Boise was $109^{\circ} \mathrm{F}$, in June 1940, and the lowest was $-17^{\circ} \mathrm{F}$, in January 1950. The total range of 
temperature during $1921-50$ was $126^{\circ} \mathrm{F}$, but this complete range, of course, never has been covered in any one year. Other pertinent temperature data are summarized in table 12.

The average number of days between killing frosts at the Boise weather station is 172 , which is a long growing season compared to that of most farming areas in Idaho. The average date for the last killing frost in the spring is April 26; that for the first killing frost in the fall is October 15.

TABLE 12.-Average temperature, in degrees Fahrenheit, at stations in Ada, Canyon, and Elmore Counties

[From records of the U. S. Weather Bureau]

\begin{tabular}{|c|c|c|c|c|c|c|c|c|c|c|c|c|c|c|}
\hline Station & Jan. & Feb. & Mar. & Apr. & May & June & $\mathrm{July}$ & Aug. & Sept. & Oct. & Nov. & Dec. & $\begin{array}{c}\text { Mean } \\
\text { annual }\end{array}$ & $\begin{array}{l}\text { Years of } \\
\text { record }\end{array}$ \\
\hline $\begin{array}{l}\text { Arrowrock Dam } \\
\text { Boise } \\
\text { Caldwell } \\
\text { Glenns Ferry } \\
\text { Meridian } \\
\text { Mountain Home. } \\
\text { Nampa }\end{array}$ & $\begin{array}{l}24.9 \\
27.3 \\
28.3 \\
29.2 \\
28.6 \\
27.8 \\
29.4\end{array}$ & $\begin{array}{l}30.5 \\
34.0 \\
34.7 \\
35.4 \\
34.6 \\
33.4 \\
36.0\end{array}$ & $\begin{array}{l}39.0 \\
41.8 \\
42.8 \\
43.9 \\
42.7 \\
40.6 \\
41.9\end{array}$ & \begin{tabular}{|l|}
48.7 \\
49.9 \\
50.9 \\
51.6 \\
50.4 \\
48.6 \\
52.0
\end{tabular} & $\begin{array}{l}57.1 \\
58.1 \\
57.9 \\
59.5 \\
57.7 \\
56.0 \\
58.4\end{array}$ & $\begin{array}{l}64.6 \\
65.1 \\
65.2 \\
68.0 \\
65.0 \\
63.3 \\
64.2\end{array}$ & $\begin{array}{l}74.5 \\
74.8 \\
73.5 \\
77.5 \\
73.1 \\
72.2 \\
74.5\end{array}$ & $\begin{array}{l}72.6 \\
72.5 \\
70.3 \\
74.0 \\
70.7 \\
69.5 \\
73.0\end{array}$ & $\begin{array}{l}62.2 \\
62.4 \\
61.0 \\
62.8 \\
61.2 \\
59.9 \\
61.3\end{array}$ & \begin{tabular}{|l|}
50.9 \\
52.6 \\
52.2 \\
51.3 \\
51.6 \\
50.3 \\
53.4
\end{tabular} & \begin{tabular}{|l|}
37.4 \\
39.6 \\
38.8 \\
39.6 \\
39.2 \\
38.2 \\
39.9
\end{tabular} & \begin{tabular}{|}
27.6 \\
31.0 \\
30.4 \\
30.8 \\
30.6 \\
29.6 \\
32.5
\end{tabular} & $\begin{array}{l}49.2 \\
50.8 \\
50.5 \\
52.0 \\
50.4 \\
49.1 \\
51.4\end{array}$ & $\begin{array}{r}1912-45 \\
1921-50 \\
1905-45 \\
1918-45 \\
1911-45 \\
11912-52 \\
11894-52\end{array}$ \\
\hline
\end{tabular}

1 Records are intermittent.

\section{WIND AND EVAPOTRANSPIRATION}

The prevailing wind in the Boise area is southeast, and the average velocity is 9.5 miles per hour. The greatest velocity recorded at Boise was 61 miles per hour in July 1944.

Evaporation from open-water surfaces in land pans has been measured at Arrowrock Reservoir and Lake Lowell during the growing season (table 13). The estimated average yearly rate of evaporation, adjusted to the reservoir water surface, is 33 inches at both stations.

Transpiration by plants is most rapid during the growing season, though a small amount of water is transpired in other periods. The wide range of transpiration rates for common crops in the Boise Valley makes it difficult to determine an average rate for the entire irrigated area in the valley. The rate commonly assumed is 2.2 acrefeet per acre, which is adopted here. Consumptive use of water on the nonirrigated lowland is assumed to be 0.6 acre-foot per acre per year. This rate may be lower than that at which native plants would consume water if it were available during the growing season, but in the Boise Valley a large part of the yearly precipitation falls during the nongrowing season. At Boise, for example, the long-term average annual precipitation is 11.48 inches (table 8). Precipitation during the growing season, April through September, however, is only 3.88 inches, whereas precipitation during the nongrowing season, October through March, is 7.60 inches. Although winter precipitation restores soil moisture, the native vegetation of the lowland is largely grass, 
sagebrush, and other common plains plants that grow well where the total annual precipitation is no more than 6 to 8 inches.

TABLE 13.-Estimated average evaporation from open-water surfaces, Arrowrock Reservoir and Lake Lowell

[Based on discontinuodus rečords for class A land pans of the U. S. Weather Bureau. Evaporation in inches of water; temperature in $\left.{ }^{\circ} \mathrm{F}\right]$

\begin{tabular}{|c|c|c|c|c|}
\hline \multirow{3}{*}{ Month } & \multicolumn{4}{|c|}{$\begin{array}{l}\text { Monthly average temperature and evaporation } \\
\text { from land pan }\end{array}$} \\
\hline & \multicolumn{2}{|c|}{ Arrowrock Dam ${ }^{1}$} & \multicolumn{2}{|c|}{ Lake Lowell ${ }^{2}$} \\
\hline & $\begin{array}{c}\text { Tempera- } \\
\text { ture }\end{array}$ & $\begin{array}{c}\text { Evapora- } \\
\text { tion }\end{array}$ & $\begin{array}{c}\text { Tempera- } \\
\text { ture }\end{array}$ & $\begin{array}{c}\text { Evapora- } \\
\text { tion }\end{array}$ \\
\hline $\begin{array}{l}\text { January } \\
\text { February } \\
\text { March } \\
\text { April } \\
\text { May } \\
\text { June } \\
\text { July } \\
\text { August } \\
\text { September } \\
\text { October } \\
\text { November } \\
\text { December }\end{array}$ & $\begin{array}{l}24.9 \\
30.5 \\
39.0 \\
48.7 \\
57.1 \\
64.6 \\
75.5 \\
72.6 \\
62.2 \\
50.9 \\
37.4 \\
27.6\end{array}$ & $\begin{array}{l}{ }^{* 0} \\
{ }_{0}^{* 0} \\
{ }^{* 1.5} \\
3.70 \\
.6 .39 \\
7.26 \\
10.64 \\
7.47 \\
5.80 \\
2.41 \\
* .60 \\
{ }^{*} 0\end{array}$ & $\begin{array}{l}29.4 \\
36.0 \\
41.9 \\
52.0 \\
58.4 \\
64.2 \\
74.5 \\
73.0 \\
61.3 \\
53.4 \\
39.9\end{array}$ & $\begin{array}{l}* 1.0 \\
* 1.5 \\
* 2.1 \\
* 4.3 \\
* 5.8 \\
6.91 \\
7.95 \\
6.86 \\
4.97 \\
* 3.7 \\
* 2.0 \\
* 1.0\end{array}$ \\
\hline Total (land pan) ...... & n... & 47.8 & 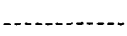 & 48.1 \\
\hline Total, adjusted to reservoir water surface....... & n....... & 333 & & 333 \\
\hline
\end{tabular}

1 Records from 1916 to 1948 for season April through October.

2 Records from 1916 to 1925 for season June through September. Temperature record is for Nampa.

3 Adjusted by multiplying land-pan total times 0.69. (See Follansbee, 1934.)

* Estimated by graphic comparison with records from stations at climatically similar locations in south. western United States.

The vegetative cover on the eastern upland is not homogeneous, and the average rate of consumptive use of water is here assumed to be 0.9 acre-foot per acre per year. Fully forested areas consume considerably more moisture, but proportionately little of the area is fully forested. Substantial areas are occupied by upland shrubs, and much of the region is grassland. An average consumptive rate of 0.9 acrefoot per acre per year is believed to be reasonable.

Consumptive use of precipitation on the northern highland is assumed to average 0.6 acre-foot per acre per year. Most of the area is occupied by native grass and upland shrubs. Much of the soil is coarse and permeable, having a lower capacity to retain moisture than the lowland soil. Inasmuch as there is little surface runoff, it is believed that a substantial portion of precipitation percolates below the root zone and recharges ground water.

\section{TOPOGRAPHIC FACTORS INFLUENCING WATER SUPPLY}

The chief topographic factors that influence water supply are altitude and relief. Other things being equal, precipitation at higher altitudes is greater than at lower altitudes, as is illustrated by records from weather stations in the Boise River basin (fig. 8). The influence 
of relief and landforms on precipitation, on the other hand, is illustrated by weather records for Mountain Home, on the plateau, and for the Arrowrock station, which is in a rugged mountain valley. The altitude at Arrowrock is only 74 feet higher than at Mountain Home, but precipitation at Arrowrock is nearly double that at Mountain Home.

In the Boise River basin the range of altitude in the lowland is from about 2,200 to 3,000 feet, but the mountainous watershed rises to altitudes as high as 8,000 feet. As is generally the case, air masses moving over the flat lowlands and plateau precipitate relatively little moisture. The air masses are forced to rise, however; where they pass over foothills and mountains. The rising air is cooled, causing condensation of moisture and precipitation in the foothills and mountains. For these reasons precipitation in the Boise Valley is low, but precipitation in the eastern upland is much greater. Thus the original source of most runoff in the Boise River is precipitation at altitudes above 3,000 feet in the eastern upland.

Surface altitudes in the Mountain Home plateau range from 2,200 to 3,200 feet and relief at most places is low. Air masses that move

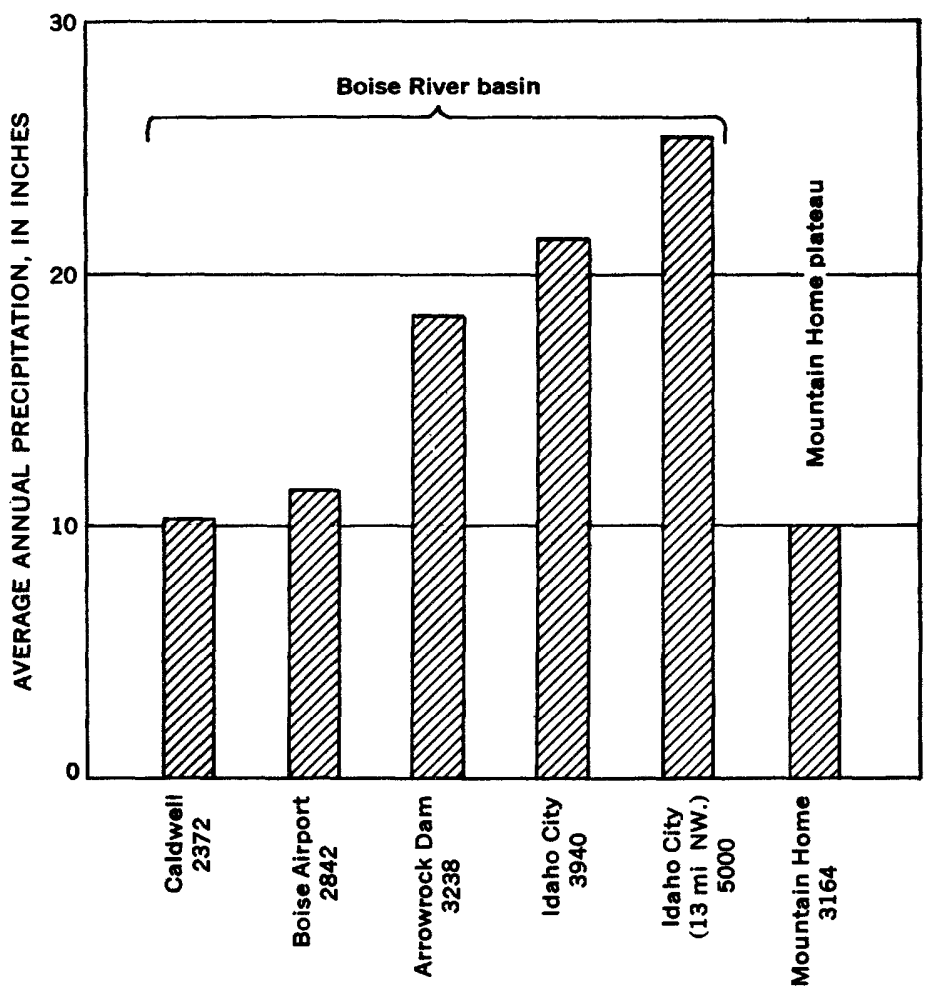

WEATHER STATION AND ALTITUDE, IN FEET

FIGURE 8.-Graph illustrating variations in precipitation at different altitudes. 
eastward over the plateau do not rise sharply until they are east of it, and the plateau therefore receives little precipitation.

The relief of the land surface influences also the rate and amount of runoff and the amount of water that percolates into the ground. The steep mountain slopes in the eastern upland are conducive to rapid runoff and small infiltration. The relatively low relief in the Boise Valley and on the Mountain Home plateau, however, favors slower runoff and more infiltration. Depressions without surface drainage are common on the plateau, and local surface runoff into these is dissipated by evaporation and infiltration.

In areas where recharge of ground water is by downward percolation to a homogeneous aquifer, the configuration of the water table tends to be a subdued replica of that of the land surface. Commonly, however, the rate of downward percolation is not uniform through a large area; also, there are both horizontal and vertical variations in the porosity and permeability of aquifers, so that the configuration of the water table at many places is quite complex. In general, within a limited area, the higher the land-surface altitude the greater the depth to water, but this direct relation is modified by other factors (fig. 9):

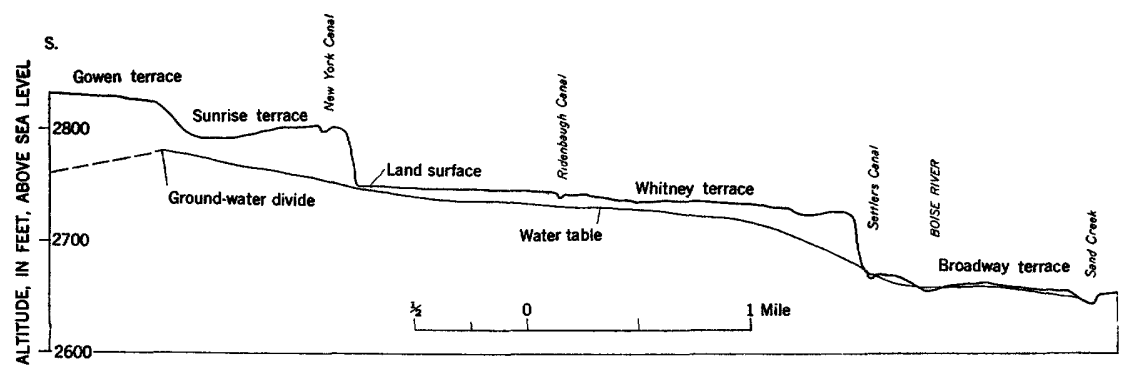

FIGURE 9.-Generalized cross section south of Boise River at Boise, showing relation of water table to land surface in summer of 1953.

The Broadway terrace in the Boise Valley is about 60 feet lower than the Whitney terrace, but the depth to water beneath each is about 5 to 15 feet. The ground water beneath the terraces is influenced strongly by subsurface geologic factors and by rapid local recharge, but the influence of topography seemingly is shown by the southward rise of the water table toward the Sunrise terrace and the ground-water divide. Farther south, however, the water table drops beneath the plateau, though the land-surface continues to rise. Recharge in the plateau is not sufficient to maintain there the near-surface water level that exists in the Boise Valley. The depth to water in the Boise Valley and the valley of the Snake River, where recharge is abundant, is generally less than 50 feet (pl. 4), whereas the depth to water beneath much of the Mountain Home plateau, an area of small recharge, is several hundred feet. 


\section{WATER MANAGEMENT}

The discharge characteristics of the Boise and Snake Rivers are influenced by storage, diversion, flood-control, and power-generation dams and by return flow of water from irrigated areas. The flow of many tributaries, including ephemeral streams, also is regulated. Modification of the regimen of surface streams has a less obvious counterpart in modification of the ground-water regimen. Irrigation in the Boise Valley caused changes in the ground-water regimen by increasing the amount of ground-water recharge and storage. The water table at some places near Lake Lowell, for example, has risen about 140 feet since the completion of the reservoir in 1911. The cycle of annual rise and fall of the water table also has been altered. The highest water levels in a natural regimen ordinarily would occur in the late spring, immediately after the time of greatest natural recharge. In the existing regimen the annual peak occurs near the end of the irrigation season (fig. 10).

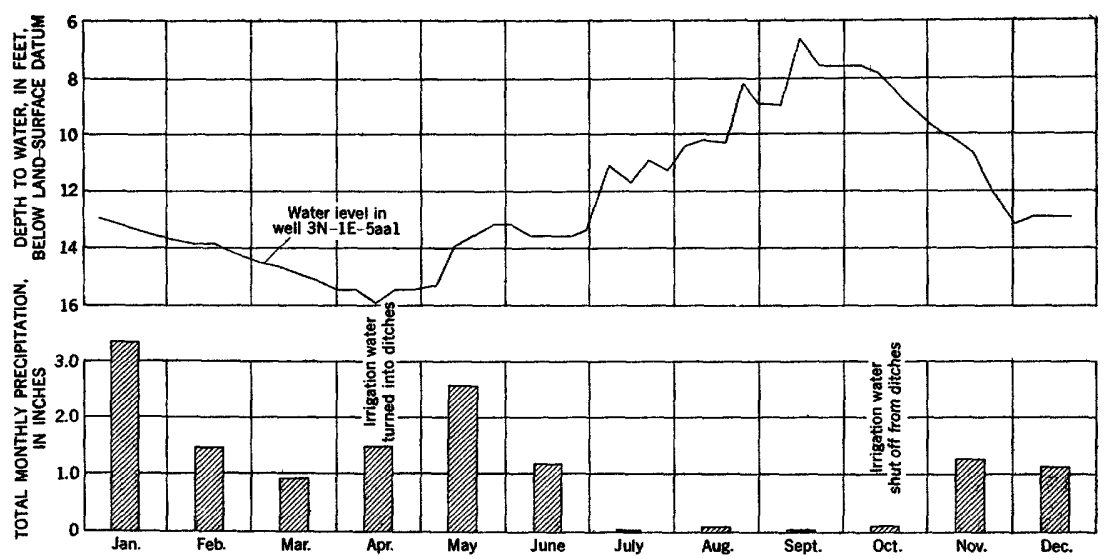

Frgore 10.-Comparisonf of total monthly precipitation at Boise Airport with water-level fluctuations In well $3 \mathrm{~N}-1 \mathrm{E}-5 \mathrm{aal}$ during 1953.

The rise of ground-water levels has been accompanied by an increase in ground-water discharge to the Boise River, further changing the regimen of that stream. Withdrawal of ground water through wells and surface drains also affects the ground-water and surface-water regimens. Inasmuch as additional wells and drainage works are constructed each year, alteration of the regimen is continuous, and an equilibrium among ground-water recharge, storage, and discharge never has been reached since irrigation began. Heavy pumping of ground water in the Boise Valley under the alternate plan for the Mountain Home project would be an additional disturbing influence, and many years might be required to reach equilibrium. Application 
of water on the Hillcrest division would materially alter the regimen of that area by increasing ground-water recharge and probably by causing new zones of ground-water discharge to develop along terraces adjacent to that division at the southern edge of the Boise Valley. A change in the amount of Boise River water that is applied for irrigation and exporting of river water from the basin, as proposed in the alternate plan, also would alter materially the river and ground-water regimens.

\section{GENERAL WATER-SUPPLY PATTERNS}

The water-supply patterns in each of the three subdivisions, Boise Valley, Mountain Home plateau, and Snake River valley, are distinctive and characteristic. Water utilization under the alternate plan, to be effective, would have to be designed within the limitations imposed by the existing supply patterns, especially in the Boise Valley.

\section{VALLEY OF THE BNAKE RIVER}

The Snake is one of the most thoroughly regulated rivers in North America. A series of storage and hydropower reservoirs and irrigation diversions on the river for several hundred miles above Swan Falls regulates the river so thoroughly that during some dry seasons the flow past the Mountain Home plateau is derived chiefly from large springs a few miles above Glenns Ferry. The river has but few perennial tributaries in the reach here discussed, and the surface increment from these and many intermittent tributary creeks, chiefly on the south side of the river, is relatively small. On the north side the only perennial tributaries are very short ones, fed by minor springs in the canyon walls and slopes. The average calendar-year annual discharge of the Snake River at Swan Falls during the base period was $7,164,000$ acre-feet. There are no gaging stations on the river between Swan Falls and Weiser, Idaho, about 100 miles downstream, and there are few records for local tributaries, so that gains in the river reach adjoining the Mountain Home plateau cannot be segregated.

Ground water in the Snake River valley has not been studied. Small supplies are obtained locally from shallow aquifers. Deep wells in lake beds at several localities tap warm artesian water, but the potential of this source has not been explored. In the canyon and valley slopes there are a few small springs, and locally wells have tapped rather large supplies of ground water in basalt aquifers. This water is believed to be recharged chiefly by local irrigation.

\section{MoUntain home PLateau}

The Mountain Home plateau lacks perennial streams. Several small mountain-fed streams, such as Long Tom Creek, extend for short distances onto the northeastern part of the plateau, where the 
flow terminates because upland discharge is too small to maintain the streams across the plateau. Most precipitation on the plateau becomes soil moisture, and perennial runoff is neglibible. Rattlesnake and Canyon Creeks flow intermittently southwestward to the Snake River across the southeastern part of the plateau. Tenmile and Indian Creeks flow intermittently northwestward to the Boise Valley across the northern part of the plateau. The discharge volume of these creeks on the plateau is not known. Most precipitation that is not absorbed as soil moisture percolates through permeable materials and becomes ground-water recharge.

Ground water in the plateau has not been studied. Available information indicates that in much of the plateau the depth to waterbearing materials is great, ranging from a few hundred feet to nearly 1,000 feet. There seems to be artesian pressure at some places but water does not rise in wells more than a few score or hundreds of feet above the level at which it is tapped. Pumping lifts therefore generally are high. Locally, as in the vicinity of Mountain Home, there is an appreciable amount of perched ground water in shallow gravel aquifers. This water is recharged by underflow from adjacent mountain slopes and by losses from irrigation water that is obtained from local streams. Natural discharge of ground water from the plateau is through springs and seeps in the valley of the Snake River. The contribution, however, is such a small percentage of the total flow of the Snake River that the increment probably could not be detected by ordinary stream-gaging methods.

The perennial supply of ground water in the plateau is adequate for farm and rural domestic supply, and for local irrigation developments. The high pumping lifts and expense of deep-well drilling, however, would be an important factor to homesteaders on reclamation farms.

\section{BOISE VALIEY}

The Boise Valley is the gathering ground for water collected in a catchment area several times its own size. The factors that influence the occurrence of water in the valley-geology, climate, topography, and water management-all favor a large perennial surface-water supply, a large volume of ground water in storage, and a large volume of perennial ground-water recharge and discharge. Moreover, aquifiers at relatively shallow depth yield water copiously, at low pumping heads, to wells of comparatively simple design. Nevertheless there is considerable local variation in the capacity of aquifers to yield water and in the susceptibility of shallow saturated zones to drainage by pumping. The pattern of these variations, in relation to the patterns of water demand, water availability, and drainage needs, is a decisive element in the feasibility of the alternate plan. 
With Anderson Ranch Dam and Lucky Peak Dam completed, substantial regulation of the Boise River after 1955 is assured. In Arrowrock and Anderson Ranch reservoirs the total active storage capacity is 709,000 acre-feet according to records of the Bureau of Reclamation in 1954, and the gross capacity of Lucky Peak reservoir is 280,000 acre-feet. During future operation it is expected that space in all reservoirs will be used jointly for irrigation, flood control, and power generation.

During the base period the average yearly discharge of water by the Boise River to the head of the Boise Valley was $1,760,000$ acrefeet (table 6); the average diversion of live water at Boise Diversion Dam was 1,280,000 acre-feet, or nearly 73 percent of the total discharge (Bureau of Reclamation records, 1954). About 201,000 acrefeet of live and return water was diverted from the river between the diversion dam and the Notus gaging station, so that the average recorded diversion from the river was 1,481,000 acre-feet (table 6), equivalent to 84 percent of the total live discharge. The observed residual discharge past Notus was 701,000 acre-feet.

Lands in the irrigation districts are served by a complicated network of canals (pl. 3) and an equally complex net of drainage ditches. The drains acquire surface waste and effluent ground water, and much of this is diverted and reused. The lower reaches of Tenmile and Indian Creeks function as drains for waste irrigation water and effluent ground water. Discharge records for the drains are available for the months of April to September; a small amount of natural runoff is included in the reeords.

Available estimates from the Bureau of Reclamation (1954) of water-diversion requirements and duty of water indicate the following: (1) the recorded average diversion of $1,280,000$ acre-feet of live water does not represent a full supply of water for all irrigated land. About 1,400,000 acre-feet of live water, plus return-flow diversions, would be a full supply. (3) In recent years of ample water supply, live-water diversions have approached the full requirement; the total volume of diversions, including live and return water from the Boise River, plus recorded diversions directly from drains, has exceeded $1,800,000$ acre-feet per year; unrecorded mass return directly into canals and laterals probably raises the gross volume to at least 2,000,000 acre-feet. (4) The average net diversion requirement from all sources for a full supply of water is not less than 5.8 acre-feet per acre, and probably is about 6.0. These and related data were the basis for original-plan estimates of water requirements for the Payette unit, Mountain Home project.

Based on the above data, the average duty of various classes of water for the entire irrigated area of 340,000 acres has been computed (table 14). 
TABLE 14.-Duty of surface water for irrigation in Boise Valley

\begin{tabular}{|c|c|c|}
\hline Class of water & $\underset{\text { (aere-ft/yr) }}{\text { Amount }}$ & $\begin{array}{l}\text { Duty 1 } \\
\text { (acre-ft/ } \\
\text { acre/yr) }\end{array}$ \\
\hline $\begin{array}{l}\text { Live water: } \\
\text { Recorded diversions (base period) } \\
\text { Full supply, base period (also for current operation) } \\
\text { Mixed water (live plus return): } \\
\text { Recorded diversions from river above Notus (base period) } \\
\text { Total recorded diversions from river and from drains (years of ample water } \\
\text { supply). } \\
\text { Total recorded diversions, plus unmeasured mass return to canais and laterals } \\
\text { (estimated; years of ample water supply) }\end{array}$ & $\begin{array}{l}1,280,000 \\
1,400,000 \\
1,481,000 \\
1,800 ; 000+ \\
2,090,000\end{array}$ & $\begin{array}{l}3.8 \\
4.1 \\
4.4 \\
5.3 \\
5.9\end{array}$ \\
\hline
\end{tabular}

1 Computed on basis of 340,000 acres. No allowance is made for supplemental ground-water supply which is sufficient for an equivalent area of 23,000 acres (see p. 17). Much of the pumped ground water goes into drains and laterals and probably is included in the recorded diversions.

The preceding discussion does not take into account the contribution of live water from small Boise River tributaries west of Boise Diversion Dam. The supply from them is not accurately known but is a negligible percentage of the total surface supply. Most of the tributary flow during the irrigation season is diverted before it reaches the Boise River.

A substantial percentage of land in the Boise Valley requires drainage. Data on the acreage involved are fragmentary, but the map (pl. 4) showing the depth to water in the Boise Valley in 1953 suggests the magnitude of the problem. In general, where the depth to water is less than 10 feet there is potential danger because, in fine-grained soil, the capillary fringe may reach to or near the surface or a period of rising water levels may bring the water table dangerously high. The depth to water is less than 10 feet in about 100,000 acres south of the Boise River, or about 29 percent of the irrigated area. The Pioneer and Nampa-Meridian Irrigation Districts probably contain the largest proportion of damaged or threatened land. In the Pioneer district about 19,000 acres out of 34,500 ( 55 percent) requires drainage. Generally satisfactory results have been obtained by pumping wells. In the Nampa-Meridian district about 29,000 acres, or 36 percent of its total area, needs drainage. The district has a very active drainage program, including both wells and gravity drains.

Many wells are present already in the Boise Valley within the area of potential heavy draft under the alternate plan (pl. 3). In parts of this area the most prolific aquifers are artesian, but nonartesian water also is the cause of much waterlogging. Existing wells in the valley annually withdraw nearly 150,000 acre-feet of artesian and nonartesian water, including 132,000 acre-feet that is used for irrigation. Many of these wells, and thousands of farm and domestic wells, are constructed and operated on the basis of a very shallow water table or high artesian-pressure surface. Great lowering of water levels and artesian pressures, caused by a concentrated heavy draft on ground 
water under the alternate plan, would affect existing use of ground water, and that effect would have to be considered.

Most existing water wells are in the central part of the valley, in a wide belt extending northward from Lake Lowell to Nampa and Caldwell, thence across the river to Notus and Parma (pl. 3). Important groups of wells occur also around Meridian, Eagle, and Boise, and there are many wells west of Nampa and Caldwell.

The alternate plan proposes to pump replacement ground water only on the south side of the Boise River. Diverted river water, however, is divided between the north and south sides and about 17 percent $(58,000$ acres) of the irrigated land is on the north. Presumably about 17 percent of the diverted surface water goes to the north and roughly the same percentage of ground-water recharge from irrigation occurs on the north side. Moreover, an undetermined large percentage of the north-side lands needs drainage. Water in major drains, such as Elijah drain, is gathered south of the river and diverted across to serve land on the north. Further, some of the water pumped from drainage wells in the Pioneer Irrigation District is discharged to canals that carry water to downstream irrigation districts.

Such is the pattern of water supply and water use which the alternate plan proposes to modify by exporting 34 percent of the total live water in the Boise River basin, by importing replacement water from the Snake River, and by pumping from the ground twice the amount of water that already is being obtained from wells. These modifications obviously would be substantial and bold.

\section{TOTAL WATER SUPPLY}

The total water supply of an area consists of all the surface water and all the ground water. The available supply is the portion of the total that can be recovered before it passes from the area. The usable supply is the amount that can be economically recovered and used. Among irrigators "usable" has the connotation of being economically divertible and usable for irrigation. However, water that is unusable for irrigation may be available and potentially usable for industrial and other purposes. Inasmuch as some water may be used and reused several times before it leaves the basin, each reuse may be treated as an addition to the total usable supply. In this report the word "usable" means accessible and divertible for any use, and the total is called the effective potentially usable supply.

The alternate plan is concerned directly only with irrigation, drainage, and power, but industrial development is a necessary part of the economy and also is dependent on the water supply. Inasmuch as practically the entire yield of surface water in the Boise Valley that 
is usable for irrigation already is being used, the success of the alternate plan would depend upon the availability of a total water supply sufficiently plentiful to allow export of 600,000 acre-feet of water yearly. An estimate of the total supply for the Boise Valley follows; the Snake River supply is not discussed because obviously it far exceeds the maximum draft that would be imposed on it under the alternate plan; the relatively insignificant surface-water supply on the Mountain Home plateau has little bearing on the water-exchange problem and there is no provision in the alternate plan for pumping ground water for irrigation on the plateau. The ground-water supply on the plateau is adequate for farm and domestic supply on new lands.

SURFACE WATER

USABLE SUPPLY

The average surface-water yield of the Boise River basin above Boise Diversion Dam during the base period was 1,760,000 acre-feet. a year (table 6). About 480,000 acre-feet of live water was spilled past Boise Diversion Dam. Part of that spill served downstream river rights and part was unused winter flow. Not all the spill, therefore, was surplus that would have been usable for irrigation. The usable surplus of river water depends on the timing of natural flow and on reservoir and diversion operations. According to Bureau of Reclamation reservoir-operation studies, the average surplus usable for irrigation during the base period was 365,000 acre-feet a year. The figure, 330,000 acre-feet, which has been published (U. S. Bur; Reclamation, 1950b), was based on older operation studies for the period 1922 through 1946.

Evidently, the average upstream surplus is more than adequate to meet the alternate-plan demand for 225,000 acre-feet of surplus Boise River water (to which would be added 375,000 acre-feet of nonsurplus water, to be replaced as described). The average surplus at Boise Diversion Dam, however, does not necessarily indicate an adequate surplus in the South Fork of the Boise River at the point where diversion to the Mountain Home project would be made. This would be especially true in years of low flow. Moreover, in 6 of the 20 years from 1931 through 1950, the volume of recorded diversions from the Boise River above Notus exceeded the flow at Boise Diversion Dam in amounts ranging from 3,865 to 107,640 acre-feet. In those years there was little or no surplus river water above Boise Diversion Dam.

During the base period the average residual discharge of the river past Notus was 701,000 acre-feet (table 6). Nevertheless, in many or most years, there was a reach of the river between Eagle Island and the eastern boundary of Canyon County where there was essentially no 
flow. Obviously, in such years all live water is diverted upstream and the discharge past Notus is surface return and discharged ground water. Records of inflow, and of rediversion and reuse of water from drains, are incomplete and the quality of some records is poor. The live discharge of small tributary streams between Boise Diversion Dam and Notus also is poorly documented. Thus the water budget for the valley cannot be accurately balanced. Using river records for the base period only, the apparent average net gain of water in the river above Notus was 422,000 acre-feet a year (table 6). Assuming that all water in the river above Notus is potentially usable, the average potentially usable supply in the river above Notus is $2,182,000$ acrefeet (recorded diversions of $1,481,000$ acre-feet plus residual flow of 701,000 acre-feet past Notus).

The residual flow of water past Notus includes a small amount of live water from small tributary streams. Runoff in Cottonwood Creek was 2,380 acre-feet in 1940 and 1,680 acre-feet in 1941. A tributary of Dry Creek yielded 4,200 acre-feet from December 1911 to May 1912. The total runoff of north-side tributaries may be on the order of 10,000 to 15,000 acre-feet a year, largely during seasons when the water is not usable for irrigation.

Most of the water supply above Notus is available for use because very little water is needed in the river channel to dilute industrial and sewage waste. The Boise sewage-treatment plant is a large source of sanitary waste, but effluent from this plant is virtually innocuous. (Clare, H. C., Idaho State Department of Public Health, oral communication, 1954). At Caldwell and vicinity untreated sewage and industrial waste require dilution with river water. The minimum desirable river flow has not been determined but depletion of the flow at or below Caldwell might create a health hazard.

\section{SURFACE-WATER DEPLETION}

The estimated average consumptive use of water by irrigated crops in the Boise Valley is 2.2 feet a year, of which about 0.4 foot is soil moisture supplied by direct precipitation, and about 1.8 feet is diverted surface water. The ratio between consumed precipitation and consumed irrigation water varies from year to year, depending on the weather and on the relative patterns of irrigation and precipitation. Accurate values for the ratio are not available but, so far as is apparent from published data, the assumed total consumptive use of 2.2 feet is reasonably accurate. The principal importance to this report of the volumes of precipitation and irrigation water that are consumed is for the related computation of the volumes of ground-water recharge by unconsumed portions of the water (see p. 41-47). If it is desired to assume a ratio different from 0.4 to 1.8 , the computations can be 
adjusted readily. In any event, the total volume of potential groundwater recharge from precipitation and irrigation is the same, regardless of the ratio, so long as the total consumptive-use requirement of crops is being met.

Farm delivery of surface water in the Boise Valley ranges from about 4.0 to 4.5 acre-feet per acre. The area under surface-water irrigation is 340,000 acres, but supplemental ground water from wells is sufficient to supply the equivalent of 23,000 acres (see p. 17). The net area dependent on surface water thus is 317,000 acres, on which the estimated consumptive use is about 571,000 acre-feet a year.

The estimated rate of evaporation from Lake Lowell is 33 inches a year (table 13), of which 8.43 inches is available from precipitation; the remainder is Boise River water. The volume of evaporation from 9,835 acres of lake surface is about 27,000 acre-feet, of which 6,900 acre-feet is from precipitation and 20,100 acre-feet is Boise River water. The computed net consumptive depletion of surface water thus is 590,700 acre-feet.

The observed net depletion of Boise River water above Notus is $1,059,000$ acre-feet. The actual net depletion probably is somewhat greater because outflow at Notus includes flood and storm runoff from small tributary creeks whose contributions are not gaged. Inasmuch as live-water contributions by these streams may be appreciable, depletion of Boise River water above Notus is here assumed to be $1,070,000$ acre-feet a year.

\section{GROUND WATER}

The perennial yield of ground water in the Boise Valley can be approximated roughly from precipitation and streamflow records, consumptive-use requirements, water-bearing characteristics of geologic materials, peculiarities of the local hydrologic cycle, and observational ground-water data.

\section{WATER FROM THE EASTERN UPLAND}

About 70 percent of the Boise River basin is above an altitude of 3,000 feet. Precipitation on the upland is relatively heavy, chiefly as snow; there most of the water supply of the Boise Valley originates. Precipitation on the eastern upland above Boise Diversion Dam is largely on steep mountain slopes formed by granitic rocks of the Idaho batholith and local volcanic rocks. These rocks store and transmit relatively little water, owing to their low porosity and permeability. The mountain soils are mostly thin and coarse, holding only moderate amounts of soil moisture, so most snow melt runs off rapidly into the valleys. Some valleys contain a fairly large quantity 
of ground water stored in substantial accumulations of sand and gravel, from which the water is fed gradually into streams.

At the junction of Moore Creek and the Boise River, about 5 miles below Arrowrock Dam, practically all the water from the mountainous eastern upland is funneled into a narrow valley that is bounded on either side by granitic and volcanic rocks. These rocks form a nearly impermeable floor beneath accumulations of permeable alluvium, and most of the water originating in the eastern upland apparently is at the surface in the river channel from the vicinity of the mouth of Moore Creek to Boise Diversion Dam. Ground-water underflow probably is relatively small, owing to the small cross-sectional area of saturated permeable alluvium. Below the dam the river debouches onto the floor of the Boise Valley. ${ }^{6}$

The amount of water that leaves the mountains as ground-water underflow can be computed approximately from available precipitation and runoff data and consumptive-use estimates. That is, precipitation, less consumptive use and export diversions, less surface discharge equals ground-water recharge and underflow. A rough computation (table 15) indicates a theoretical water yield of 1,795,000 acre-feet, which is 35,000 acre-feet greater than the measured surface discharge in the Boise River. The excess, equivalent to an average continuous flow of about $48 \mathrm{cfs}$, apparently is ground-water underflow in the vicinity of Boise Diversion Dam and through the highland north of the dam. Rocks in the vicinity of the dam do not seem to be capable of transmitting a large quantity of water. Substantial westward flow through the northern highland seems unlikely, and no area is known where a large amount of water could escape by underflow. The apparent small discharge from the eastern upland, therefore, is consonant with observable hydrologic characteristics of the rocks and sediments through which the water must pass. Owing to the approximate nature of the computations in this report, the apparent rate of ground-water discharge- $48 \mathrm{cfs}$-has no factual standing. It serves chiefly to indicate the general order of magnitude of ground-water underflow. Although the volume of water concerned is relatively small, it would be adequate for the farm-delivery requirement of nearly 9,000 acres of land and therefore is of significant concern to the alternate plan.

\footnotetext{
6 After this report was completed construction of Lucky Peak Dam advanced sufficiently to allow partial operation. At peak stage, water in the reservoir rises a few feet on the downstream face of Arrowrock Dam; backwater also extends a fow miles up the valley of Moore Creek. Much of the stream-valley areas here described are submerged during parts of the year. Owing to the geologic nature of the valleys, the impounding of water does not materially alter the substance of this paragraph.
} 


\section{TABLE 15.-Estimated disposition of precipitation on Boise River Basin}

[Area-volume of precipitation from table 11]

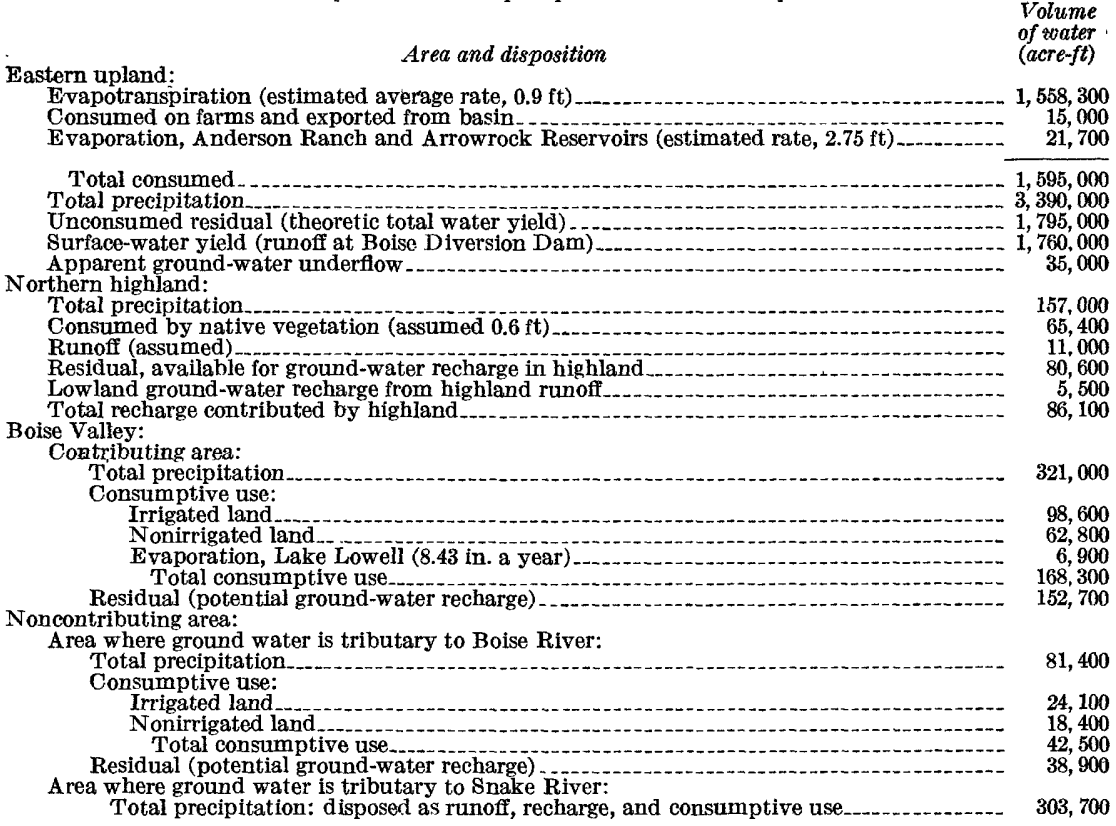

\section{WATER FROM THE NORTHERN HIGHLAND}

The area of foothills and mountains north of the Boise Valley is mostly above an altitude of 3,000 feet, but surface runoff is small, occurring chiefly as flash discharge after heavy rainstorms and rapid snow melting. Topographic influence on precipitation and geologic influence on runoff are evident. In the northern highland the rate of precipitation is less than in the eastern upland but appreciably greater than in the Boise Valley. The foothills are not forested, indicating that the amount of precipitation available as soil moisture is less than that required for forest survival. Heavy snow cover accumulates in winter on the higher ridges, which are partly forested and contain typical small mountain creeks. Small springs and seeps occur in the foothills.

Permeable beds of the Idaho formation compose most of the foothills in the northern highland, where they overlap the Idaho batholith. The sediments as a whole are coarser toward the batholith, containing many beds of gravel and coarse sand. These geologic features decisively influence the runoff characteristics of the area. The foothill sediments absorb most precipitated water except during heavy rainstorms. Small streams that drain the higher mountains lose water 
rapidly in the foothill sediments, especially in the coarser zones near the batholith. Water not needed to restore soil moisture percolates downward and becomes stored ground water, some reaching the Boise Valley in shallow aquifers, and some entering artesian aquifers and migrating to the valley at considerable depth.

Ground-water underflow from the northern highland reaches the Boise Valley far enough east to be practicably recoverable in the lowland. The contributing highland area is about 109,000 acres, on which the estimated volume of precipitation is about 157,000 acre-feet a year (table 11). The estimated disposition of this water has been shown in table 15.

\section{RECHARGE FROM LOWLAND PRECIPITATION}

Natural surface runoff in the Boise Valley is small, and most precipitation on the lowland enters the ground, where part of it restores soil moisture and part becomes ground water. The estimated disposition of precipitation shown in table 15 applies to the entire Boise Valley, including the part of the Black Canyon irrigation project that is within the Boise Valley ground-water basin, but which is irrigated with imported Payette River water. The area that contributes ground water that would be practicably recoverable from wells or drains east of Notus is segregated in table 15 from other areas.

Within the contributing area actual exchange of ground water for surface water under the alternate plan probably would be largely in an area east of Notus (fig. 11), for reasons that are discussed later in this report. That area, herein called the exchange area, includes about 233,700 acres, lying both north and south of the Boise River. The disposition of precipitation in the exchange area is estimated below, assuming that 0.6 foot of water is consumed on nonirrigated lowland and that all but 0.4 foot of the consumptive requirement on irrigated land is met by irrigation water.

\begin{tabular}{|c|c|c|c|}
\hline & $\begin{array}{c}\text { Area } \\
\text { (acres) }\end{array}$ & $\begin{array}{c}\text { Precipita- } \\
\text { tion } \\
\text { (acre-ft) }\end{array}$ & $\begin{array}{l}\text { Consump- } \\
\text { tive use } \\
\text { (acre-ft) }\end{array}$ \\
\hline $\begin{array}{l}\text { Irrigation area (water from all sources) } \\
\text { Nonirrigated area }\end{array}$ & $\begin{array}{r}218,800 \\
14,900\end{array}$ & $\begin{array}{r}195,800 \\
13,300\end{array}$ & $\begin{array}{r}87,500 \\
8,900\end{array}$ \\
\hline Total & 233,700 & 209,100 & 96,400 \\
\hline
\end{tabular}

Net potential recharge (rounded)

113,000

The summation shows that the net potential recharge from precipitation within the exchange area is about half the supposed minimum ground-water pumping requirement of the alternate plan. The amount of actual recharge from precipitation, unfortunately, is not known. Recharge is not areally uniform in the lowland because local 


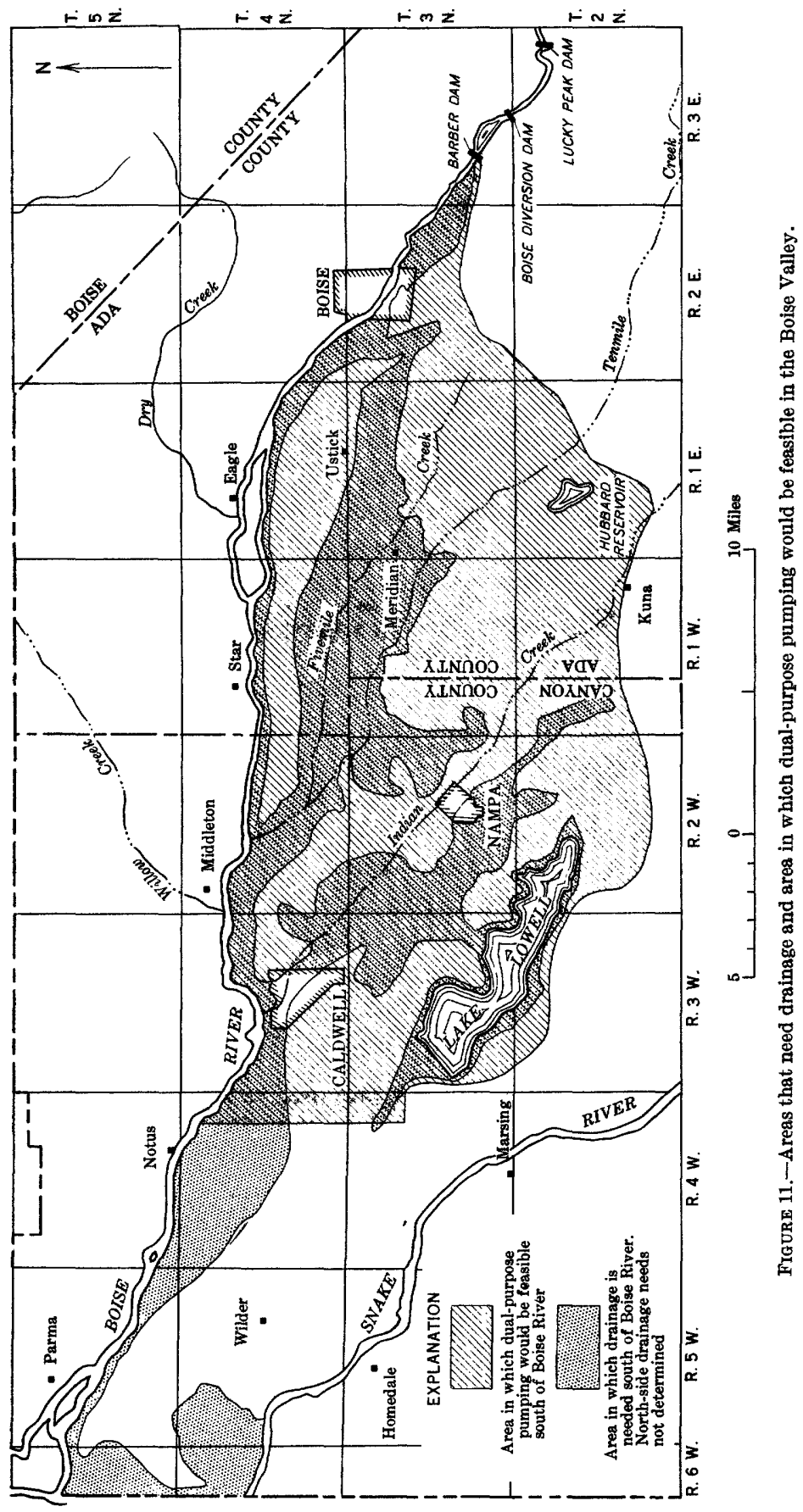


areas of saturated soil and impermeable soil reject recharge and allow local runoff. Much local runoff, however, reaches areas where recharge occurs.

RECHARGE FROM IRRIGATION

Water stored in surface reservoirs, which otherwise would run out of the basin, contributes to recharge of ground-water reservoirs during irrigation. Irrigation increases the amount of land in contact with potential-recharge water, and relieves the consumptive-use demand on precipitation, thus increasing potential recharge from precipitation. Diverted surface water that becomes ground water has been counted once already as part of the surface-water supply of the Boise Valley. The recharge water, nevertheless, is available for reuse and is a part of the usable effective total water supply. The recharge water, therefore, is treated as a basic supply.

A qualitative deduction about the volume of recharge from irrigation may be made on the basis of water-level fluctuations in wells. Recharge from precipitation causes water levels in shallow wells to rise shortly after heavy rainfall or rapid snow melting. In the Boise Valley the effects of precipitation are largely masked by water-level fluctuations induced by recharge from irrigation. The well represented by the hydrograph in figure 10 is 2 miles northeast of Meridian in the heart of the irrigation district. The water level reached a peak in mid-September 1953. Without recharge from irrigation the peak would be expected in the spring, but at that time the water table still was on the downward trend that followed the previous irrigation season, and a general rise did not begin until after irrigation water was turned into canals in April. The graph illustrates that in the vicinity of the well the amount of recharge from precipitation is substantially less than that from irrigation water. This condition probably pertains throughout the irrigated area. Hence, if actual recharge approaches the amount of the preceding estimate (that potential recharge from precipitation is about 113,000 acre-feet in the exchange area), then recharge from irrigation is substantially more than 113,000 acre-feet in the same area.

The complicated pattern of use, rediversion, and reuse of water in the Boise Valley makes most methods for estimating ground-water recharge from irrigation unmanageable. Potential net recharge from irrigation is here estimated simply on the basis of live-water diversions and consumptive use on irrigated land.

Consumptive use of surface water in the irrigated area is about 591,000 acre-feet a year (rounded amount; see p. 41). Recorded live-water diversions at Boise Diversion Dam during the base period were 1,280,000 acre-feet. The difference between the two amounts, 689,000 acre-feet, includes ungaged surface outflow, but may be con- 
sidered as potential ground-water recharge. With a full supply of live water $(1,400,000$ acre-feet; see $p .37)$ the volume of potential ground-water recharge would be 809,000 acre-feet a year. This amount apparently represents recharge that would occur if it were not rejected, and that might be accepted in the future if aquifers were dewatered by pumping. If the estimate is correct, potential recharge from irrigation over the entire irrigated area during the base period was 2.0 feet of water per year. With a full live-water supply the amount would be 2.1 feet. According to this method of computation the average potential recharge from Boise River water in the 186,000 irrigated acres of the exchange area, during the base period, was 2.0 times 186,000 or 372,000 acre-feet a year.

The New York Canal loses a few percent of live-water diversions, according to records of the Boise Project Board of Control, but some of the reported loss is believed to be surplus water at ditch ends. The water actually lost by percolation out of the canal becomes ground-water recharge, undoubtedly influencing the position of the ground-water divide (pl. 5) which approximately follows the canal. The division of the recharge water between the two sides of the divide is here assumed to be on a 50-50 basis. If the total volume of loss is 40,000 acre-feet, 20,000 acre-feet of water that was credited above as potential recharge to the Boise Valley, is actual escape recharge to the Mountain Home plateau. The residual potential recharge in the Boise Valley exchange area then is 372,000 minus 20,000 or 352,000 acre-feet a year.

The computations confirm qualitatively a previous deduction from the evidence of water-level fluctuations; namely, that in the irrigated area recharge from irrigation substantially exceeds that from precipitation. Therefore, irrigation recharge in the contributing area is much more than 113,000 acre-feet, but undoubtedly is less than the potential of 352,000 acre-feet. For later use in evaluation of the alternate plan, the average potential recharge from irrigation within the exchange area is assumed to be 320,000 acre-feet, or about 1.8 acre-feet per acre.

\section{GROUND-WATER DEPLETION}

The amount of ground water that already is being withdrawn, as well as the Jocation and concentration of withdrawals, may limit the feasibility of the alternate plan. The yearly gross withdrawal currently is about 150,000 acre-feet (rounded amount), of which 128,000 acre-feet is pumped for irrigation and drainage. Consumptive use on the 33,000 acres of equivalent and actual area irrigated with ground water (see p. 17) is about 66,000 acre-feet. Consumptive use of ground water for purposes other than irrigation is assumed to be 25 percent of the pumped amount, or about 5,500 acre-feet. 
Large tracts of land in the Boise Valley where the water table is at shallow depth are occupied by distinctive groups of water-loving plants. Some (the phreatophytes) characteristically send their roots down to the water table or the capillary fringe. Others (hydrophytes) live where the water table is at the land surface or where there is ponded water. The most prevalent water-loving species in the Boise Valley are saltgrass, wire rush, threadleaf sedge, Nebraska sedge, cottonwood, willow, cattail, and rushes. They have little or no economic value. The estimated aggregate area occupied by waterloving plants in the Boise Valley is 40,000 acres. The principal tracts of phreatophytes are in a narrow belt, as much as 3 miles wide, adjacent to the Boise River. Assuming that the average yearly consumptive use is about 4 feet (a conservative figure), these plants waste each year about 160,000 acre-feet of ground water, or more than twice the amount of ground-water depletion by all beneficial uses.

Several hundred miles of open surface drains in the Boise Valley discharge a large volume of surface and ground water in undetermined proportions. The exact volume of discharged ground water is not known but it far exceeds the amount withdrawn from wells. Disregarding drain discharge, the identifiable volume of current groundwater depletion is about 231,500 acre-feet (rounded to 232,000), an amount approximately equal to the proposed minimum withdrawal under the alternate plan.

Table 16 gives values which are believed to be reasonably approximate for the effective potentially usable water supply in the Boise Valley. The table and the preceding text ignore water imported from the Payette River to the 50,000-acre Black Canyon project, a large part of which is within the Boise River basin. This imported water and additional irrigated area materially affect the water situation in the northwestern part of the valley and would have to be given full consideration in comprehensive plans for water utilization. Irrigation on the Black Canyon project is directly related to draingge problems on the north side of the Boise River west of Middleton. Analysis of the relation of the Black Canyon project to the water situation in the Boise Valley is beyond the scope of this report.

According to the summary of estimates in table 16 the effective potentially usable supply of surface water is about 2.5 million acre-feet a year, compared to a live-water supply of 1.77 million. The groundwater potential seemingly approaches 0.6 million acre-feet, from a total perennial yield of nearly 1 million. The ratio of potential to total is less for ground water than for surface water because recharge and natural discharge of ground water are continuous whereas pumping is not continuous and could not economically intercept the total perennial yield. The computed effective potential yearly water sup- 
ply from all sources is 3.0 million acre-feet, from a total perennial yield of 2.7 million. These figures have no standing as proved fact, but are merely crude estimates. The chief significance of the summation is that the net potential water supply is very large; the gross supply of ground water above Notus far exceeds the demand of the alternate plan.

TABLe 16.-Estimated effective total water supply of Boise Valley above Notus, excluding area where ground water is tributary to the Snake River

[Rounded quantities, in thousands of acre-feet a year]

\begin{tabular}{|c|c|c|c|c|}
\hline Source of water & Total & $\underset{\text { able }}{\text { A vail- }}$ & $\begin{array}{c}\text { Usable } \\
\text { (any } \\
\text { purpose) }\end{array}$ & $\begin{array}{l}\text { Effective } \\
\text { poten- } \\
\text { tially } \\
\text { usable } \\
\text { supply }\end{array}$ \\
\hline $\begin{array}{l}\text { Surface water: } \\
\text { Boise River } \\
\text { Small tributaries of Boise River }\end{array}$ & $\begin{array}{r}1,760 \\
11\end{array}$ & $\begin{array}{r}1,760 \\
11\end{array}$ & $\begin{array}{r}1,760 \\
6\end{array}$ & $\begin{array}{r}12,501 \\
6\end{array}$ \\
\hline Total, surface water & 1,771 & 1,771 & 1,766 & 2,507 \\
\hline $\begin{array}{l}\text { Ground water: } \\
\text { Underflow from eastern upland } \\
\text { Underflow from northern highland } \\
\text { Recharge from precipitation: } \\
\text { Contributing lowland } \\
\text { Noncontributing area } \\
\text { Recharge from irrigation: } \\
\text { Contributing lowland area } \\
\text { Noncontributing area }\end{array}$ & $\begin{array}{r}35 \\
86 \\
153 \\
39 \\
\\
513 \\
125\end{array}$ & $\begin{array}{r}35 \\
50 \\
75 \\
15 \\
300 \\
50\end{array}$ & $\begin{array}{r}(2) \\
35 \\
20 \\
75 \\
15 \\
300 \\
50\end{array}$ & $\begin{array}{r}35 \\
30 \\
100 \\
20 \\
350 \\
50\end{array}$ \\
\hline Total, ground water..... & 951 & 525 & 495 & 585 \\
\hline Net total, all water. - & 2,722 & 2,296 & 2,261 & 3,092 \\
\hline
\end{tabular}

1 Effective potential in the Boise River (see text, p. 40) is 2,182,000. Effective potential in the valley was computed as $1,800,000$ (diversions plus rediversions), plus observed residual flow (701,000 acre-feet) at Notus (from table 6).

2 Amounts necessarily assumed arbitrarily.

\section{LIMITATIONS TO THE ALTERNATE PLAN IMPOSED BY THE ENVIRONMENT}

The feasibility of the alternate plan is limited by the environment, especially the ground-water features. Success of the plan would depend upon developing, at a definite time and place, a specified amount of usable ground water that could replace an equivalent (but not necessarily equal) amount of surface water originating at a remote place and at a different time. Concurrently, the ground-water pumping would have to accomplish satisfactory drainage of waterlogged land in specified areas.

Successful operation of the alternate plan would depend upon the "safe" perennial water yield of local and regional aquifers, the optimum spacing of wells, the depth and construction characteristics of wells, the pumping lifts, the local and regional effects of pumping on the flow in canals and surface drains, and on water levels generally. The economy of water management would depend upon the degree to which economical pumping of water for irrigation could be coupled 
with effective drainage. Economical water production depends on low pumping lift and small drawdown. Effective drainage may require heavy drawdown and hence greater pumping lift.

\section{IIMITING GROUND-WATER CONDITIONS}

The unconfined aquifers in the Boise Valley generally are recharged readily and would be a principal source of water in the alternate plan. Artesian aquifers also would be an important source of water because some of the artesian zones are shallow, highly permeable, and contain a substantial part of the total ground-water supply. Moreover, at shallow depth artesian and unconfined waters are not sharply differentiated and in part merge one into the other. Reduction in groundwater storage by heavy pumping under the alternate plan would convert some artesian to nonartesian aquifers.

The Boise Valley is divided on the map (pl. 5) into five groundwater districts. The names applied to these districts are not related to the somewhat similar names of irrigation and drainage districts. The Nampa district is the most favorable for ground-water pumping, and well records from the district are sufficien tly good that the probable average depth of wells under the alternate plan can be estimated. Wells having an average depth of about 120 feet (twice the valleywide average estimated in the alternate plan) would produce 2 to $3 \mathrm{cfs}$ of water with a drawdown of about 25 feet. For other districts, records are less complete and the probable average depth of proposed wells cannot be estimated. These generally less favorable districts are compared to the Nampa district, which is taken as a roughly standard area.

\section{NAMPA DISTRICT}

Wells in the Nampa district have the largest yields in the valley, owing to the generally high permeability of the younger terrace gravel and the alluvial tongue in the Indian Creek valley (see pl. 2), which constitute the principal unconfined aquifer in the district. Copious supplies of unconfined water are obtained in the southeastern part of the district from basalt and cinders (Snake River basalt). Artesian water also occurs in the basalt and sustains flowing wells in low areas, where the basalt is confined beneath caliche, impermeable soil, or impermeable beds at the base of the alluvium of Indian Creek. Unconfined water occurs in Recent alluvium along the Boise River bottom land, but there the deposit is too thin for wells to develop large yields. Artesian water underlies the entire district in sandy beds of the Idaho formation, such as those tapped by flowing wells at Nampa, Caldwell, and elsewhere. Both the unconfined and the artesian aquifers would be competent sources of water for an intensive pumping development. 
The average depth to unconfined water is between 10 and 15 feet and the maximum is less than 50 feet. The average yield per well is about 3 cfs with a drawdown of 25 feet, or $1 \mathrm{cfs}$ for each 8 feet of drawdown. The average well depth necessary to develop 2 to $3 \mathrm{cfs}$ of water is about 120 feet-that is, the well must be drilled about 100 feet below the water table.

Shallow artesian aquifers yield a few to several hundred gallons of water a minute by natural flow. Deeper wells at some places have large yields; some of them tap warm water.

A thin accumulation of alluvial and windblown clay and silt mantles much of the district. Owing to the low permeability and high specific retention of this material, canals constructed in it lose little water but gravity drains are rather ineffective. Upward leakage of artesian water through soil and caliche (hardpan) causes much of the waterlogging in the district; pumping that relieved artesian pressure would alleviate this condition.

\section{MERIDLAN DISTRICT}

Wells in the Meridian district yield somewhat less water than those in the Nampa district, owing to the lesser saturated thickness of the younger terrace gravel, which thins eastward. Basalt is inconsequential as an aquifer because it is rare in the zone of saturation. Locally, especially in the eastern part of the district, Recent alluvium is highly permeable and an excellent aquifer. Artesian water occurs at a wide range of depths in the Idaho formation, which underlies the entire district. In wells on Eagle Island artesian aquifers were penetrated at depths of 80 to 125,155 to 205 , and 230 to 412 feet. In general the Idaho formation is more firmly cemented in the eastern part of the Meridian district than in the western part, and the permeability in the east is correspondingly less.

The average depth to the unconfined water is between 10 and 15 feet and the maximum is less than 50 feet. Most good wells yield about $2 \mathrm{cfs}$ with 45 feet of drawdown, or $1 \mathrm{cfs}$ for each 22 feet of drawdown. The average well depth needed to produce 2 to $3 \mathrm{cfs}$ of water is at least 120 feet. Artesian wells yield as much as $1.5 \mathrm{cfs}$ by natural flow and $3 \mathrm{cfs}$ by pumping. Larger yields could be obtained by means of improved construction and development and larger pumps.

Drainage conditions are similar to those in the Nampa district, but unlined canals tend to lose more water because the impermeable soil mantle is thinner or absent, especially to the east. These conditions, however, favor rapid recharge of ground water. 


\section{WHDER DISTRICT}

Too little information is available to permit estimation of the average yield of wells in the Wilder district. The water-bearing: formations are similar to those in the Meridian district but are somewhat less permeable owing to finer texture, and more variable because beds of flood-plain clay and silt intertongue with the younger terrace gravel and Recent alluvium. A larger percentage of poor wells is expected in this district. The Idaho formation underlies the district, but little is known about its local water-bearing properties. Apparently it is finer in texture and less permeable than in other districts.

A large amount of ground water is pumped for high lands above the canal system near Lake Lowell, where the aquifer is the Idaho formation. Irrigation pumping from basalt aquifers in the southeastern part of the district has not been attempted but may be feasible.

The depth to unconfined water is as much as 200 feet, but in the western part of the district the average depth is less than 50 feet. The average drawdown in wells for which data are available is about 30 feet per cubic foot per second of water. The average well depth needed to produce 2 to $3 \mathrm{cfs}$ of water is considerably more than 120 feet.

Natural soil drainage is poor in much of the district because finegrained flood-plain clay and silt are underlain by similar beds in the Idaho formation. Gravity drains are weakly effective because of high specific retention of water by the fine-grained sediments. Drainage wells would be ineffective in some parts of the district for the same reason. Installation of drainage wells in this area would call for intensive preliminary investigations. The district as a whole is less favorable for drainage benefit and for ground-water recharge than are the Nampa and Meridian districts, because a large percentage of the surface is covered by fine-grained sediments.

\section{KUNA DISTRICT}

Some wells in the Kuna district yield water more copiously than do wells in other districts, but there are few wells because the great depth to water discourages drilling and pumping. Some water is pumped from the Idaho formation, where it underlies early terrace gravel southeast of Lake Lowell, to irrigate several hundred acres of high land. The average drawdown in existing wells is about 30 feet per cubic foot per second of water. Flowing wells that penetrated basalt south of Melba yield 0.5 to $13.3 \mathrm{cfs}$ by free flow. Elsewhere in the district basalt is mostly above the water table.

The depth to unconfined water ranges from 50 to more than 300 feet. Well depths averaging much more than 120 feet would be necessary to obtain yields of 2 to $3 \mathrm{cfs}$. 


\section{NORTH SIDE DISTRICT}

The alternate plan excludes the area north of the Boise River, but the features of ground-water occurrence in the North Side district resemble those in the south. The same aquifers are present in both and ground-water underflow off the northern highland must pass through the north-side tract. There is not enough information to permit subdividing the district hydrologically. Within the district wells have almost the full range of characteristics noted in other districts, except that no wells yield as copiously as those near Melba, in the Kuna district.

Recent alluvium is similar to that on the south side. The Idaho formation tends to be coarser and more permeable northward from the river toward the foothills. Artesian pressure in the beds of the Idaho formation is low, because of their increased altitude and nearness to the outcrop area. Flowing wells are uncommon except locally, chiefly near the Boise River, but a great deal of unconfined water is pumped from sand and gravel in the Idaho formation near Parma and Notus. Springs and seeps are common along the foot of a high river terrace at the boundary between Recent alluvium and the Idaho formation.

Wells of the Boise Water Corp. in Boise tap water in the Idaho formation, mostly at depths of several hundred to a thousand feet. Hot artesian water is yielded by wells 800 to 1,200 feet deep along the foothills north of Boise.

\section{WITHDRA WAL CAPACITY AND DRAINAGE EFFECT OF WELLS}

The alternate plan presumes that 225,000 to 300,000 acre-feet of water a year could be pumped from 450 wells within a limited waterexchange area. The soundness of this presumption depends directly on the capacity of wells to withdraw water efficiently from the ground because that capacity determines the number of wells required, their construction characteristics, their efficiency as combined waterproduction and drainage facilities, the electric-power demand, and other factors. Those factors, in turn, will affect both the initial and the operating costs of the plan. The withdrawal capacity depends both on the water-bearing characteristics of the aquifers and on the efficiency of the well.

The alternate plan presumes further that the pumping would lower the water table 4 feet or more beneath 225,000 acres of land-that is, within an area substantially more extensive than the lands to be served by the pumped ground water. Assuming that the area influenced by pumping will be 225,000 acres, that the yearly withdrawal will be 225,000 to 300,000 acre-feet, and that the sediments to be dewatered have an average specific yield of 25 percent, then pumpage 
during 1 year would equal the volume of water stored within a zone of the valley sediments 4.0 to 5.3 feet thick. However, in part because recharge is not considered, this fact does not justify a conclusion that, when pumping equilibrium has been reached in future years, the water table will have been lowered 4.0 to 5.3 feet within the area of influence-either uniformly or on the average.

In this context, specific yield is that volume percentage of water that will drain from saturated sediments by gravity; in other words, it is essentially equal to the coefficient of storage, or the volume percentage that can be drawn from an unconfined aquifer by pumping from wells. Specific yield varies widely among the heterogeneous sediments of the Boise Valley. The well-sorted coarse sediments yield their water readily, almost completely, and in a large percentage volume. The fine sediments yield water only slowly, incompletely, and in a smaller percentage volume. Clay and clayey silt, which are widespread in the waterlogged areas of the valley, yield little or no water. Thus, pumping a given amount of water from a fine sediment may lower the water table several times farther than pumping the same amount of water from a coarse sediment. However, in finegrained sediment such lowering of the water table may not dewater the soil sufficiently to eliminate waterlogging. In a sediment having a given uniform texture, lowering of the water table diminishes with increasing distance from each pumped well. All these variations mean that the degree of drainage benefit under the alternate plan would vary greatly from place to place in the valley.

\section{AQUTFER CHARACTERISTICS}

Fourteen aquifier tests were made by pumping at key locations in the valley. For that purpose, 2 production-test wells and 8 observation wells were drilled, and existing irrigation and drainage wells were used where feasible. The resulting data on hydraulic characteristics of the aquifers are given in table 17; computed values of probable drawdown of the water table after several intervals of pumping and at several distances from the wells are given in table 18; and the aquifer characteristics are summarized in table 19. For the drawdown estimates in table 18, it is necessary to assume homogeneous aquifers extending through large areas, which do not exist in the Boise Valley. The estimates also do not allow for the offsetting rise of the water table caused by recharge during irrigation. Actual lowering of water levels will differ from, but probably will not substantially exceed, the computed lowering. 
The coefficients of transmissibility and storage (table 17) were determined in accordance with Jacob's approximation (1947) of the nonequilibrium method (Theis, 1935). The coefficients of transmissibility for all aquifers tested range from 36,800 to $1,700,000$; that is, from moderate to uncommonly large coefficients. The observed coefficients of storage of artesian aquifers are of ordinary magnitude, ranging from 0.00007 to 0.001 . The observed coefficients of storage (essentially, the specific yields) of nonartesian aquifers range from 0.001 to 0.43 - that is, from small to unusually large. The values in table 17 are approximate for the aquifers tested, within small areas; although useful as guides to estimate effects of pumping, as in table 18, they should not be applied blanketwise to large areas.

TABLE 17.-Approximate hydraulic coefficients of some aquifers in the Boise Valley

[From drawdown and recovery curves based on pumping-test data]

\begin{tabular}{|c|c|c|c|c|c|c|}
\hline $\begin{array}{l}\text { Well Ne."and } \\
\text { lócation }\end{array}$ & Owner & Date of test & $\begin{array}{l}\text { Pump- } \\
\text { ing } \\
\text { rates } \\
\text { (gpm) }\end{array}$ & $\begin{array}{c}\text { A verage } \\
\text { coefficient } \\
\text { of trans- } \\
\text { missibil- } \\
\text { ity } \\
\text { (gpd/ft) }\end{array}$ & $\begin{array}{c}\text { Average } \\
\text { coeffi- } \\
\text { cient of } \\
\text { storage }\end{array}$ & $\begin{array}{l}\text { Average } \\
\text { fiold per- } \\
\text { meability } \\
\text { (gpd/ft') }\end{array}$ \\
\hline
\end{tabular}

North side district

\begin{tabular}{l|l|l|l|l|l|l}
\hline $5 \mathrm{~N}-4 \mathrm{~W}-28 \mathrm{ec1} \ldots$ & $\begin{array}{l}\text { Canyon County Drainage Dist. } \\
\text { No. 4. }\end{array}$ & June 1953.... & 1,030 & 324,000 & 0.025 & $\ldots$ \\
\hline
\end{tabular}

Nampa district

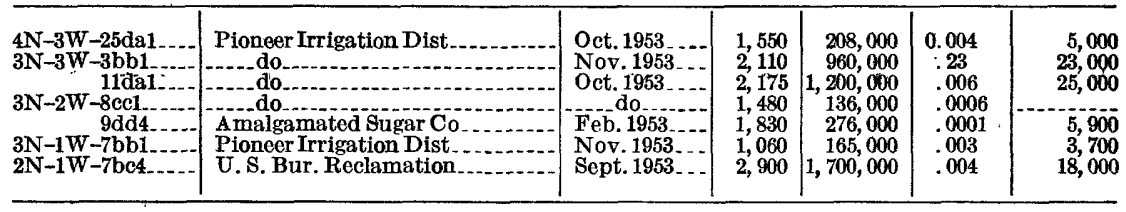

Meridian district

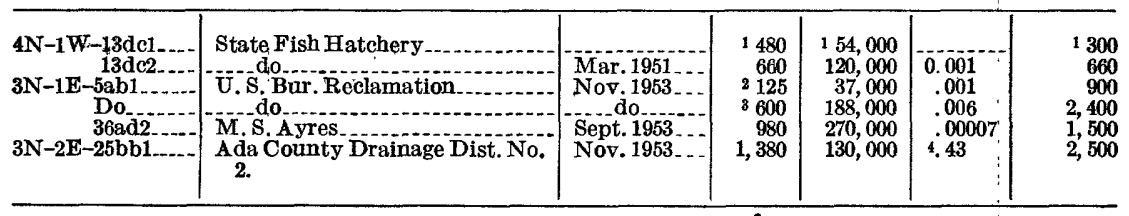

1 Data are averages of three separate tests in July and November $1950^{\circ}$ and March 1951.

2 Well taps only artesian water in sand aquifer in lower part of well; well screen in aquifer.

Well taps artesian aquifer near bottom and unconfined water at shallow depth.

True coefficient of storage probably about 0.30 or 0.35 . 

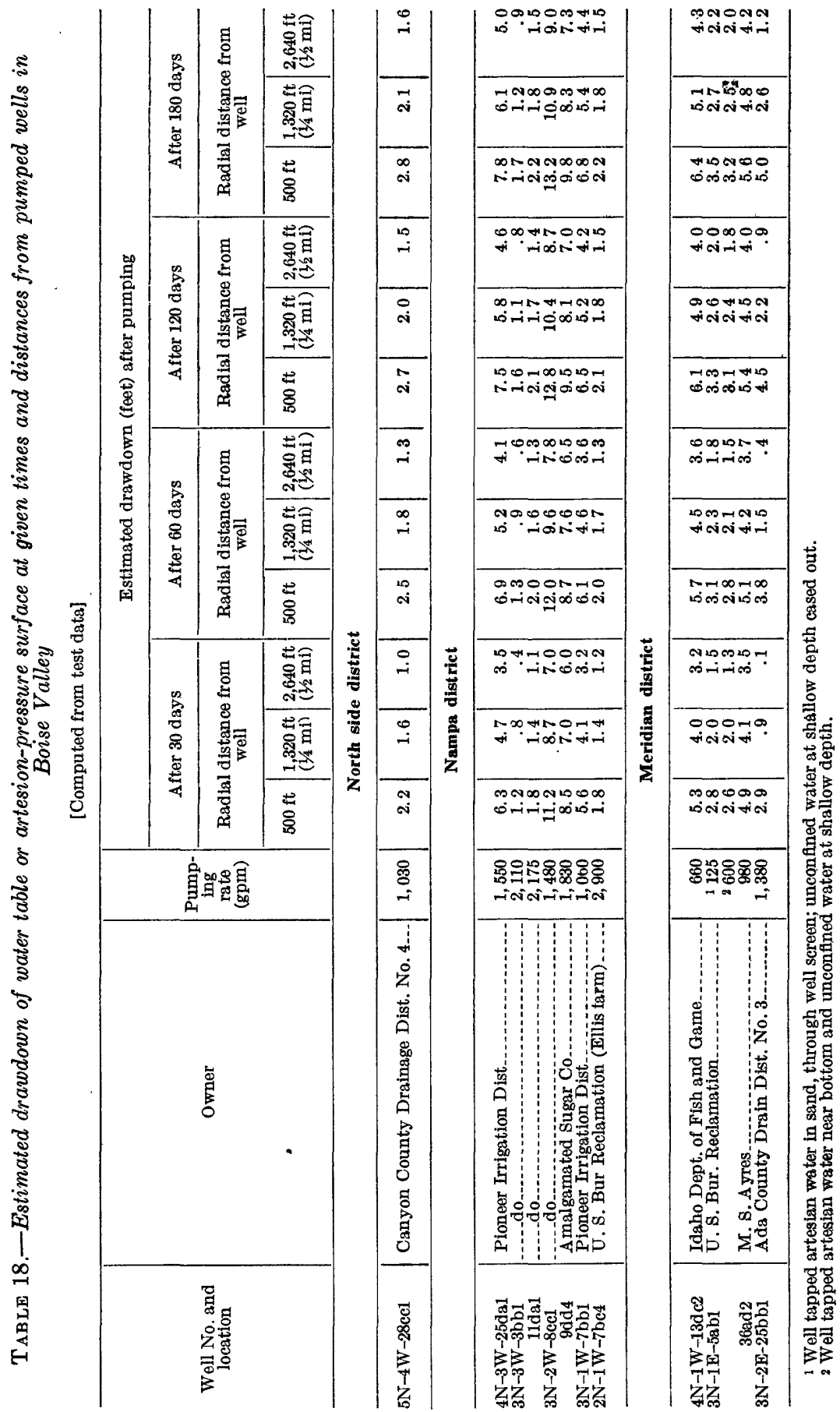
TABLE 19.-Aquifer characteristics in typical areas

\begin{tabular}{|c|c|c|c|c|c|c|}
\hline \multirow{2}{*}{ Aquifer characteristics and well data } & \multirow{2}{*}{$\begin{array}{c}\text { Pioneer } \\
\text { Irriga- } \\
\text { tion } \\
\text { District }{ }^{1}\end{array}$} & \multirow{2}{*}{$\begin{array}{l}\text { Ellis } \\
\text { farm }\end{array}$} & \multicolumn{2}{|c|}{$\begin{array}{l}\text { Ustick-Meridian- } \\
\text { Well 3.V-1 E-5ab1 }\end{array}$} & \multicolumn{2}{|c|}{ Eagle Island } \\
\hline & & & $\begin{array}{c}\text { First } \\
\text { test }\end{array}$ & $\begin{array}{l}\text { Second } \\
\text { test }\end{array}$ & $\begin{array}{c}\text { Well } \\
4 \mathrm{~N}-1 \mathrm{~W}- \\
13 \mathrm{dc} 1\end{array}$ & $\begin{array}{l}\text { Well } \\
4 \mathrm{~N}-1 \mathrm{~W}- \\
13 \mathrm{dc2}\end{array}$ \\
\hline $\begin{array}{l}\text { Pumping rate. } \\
\text { Duration of test. } \\
\text { Specific capacity of well } \\
\text { Coefficient of transmissibility } \\
\text { Coefficient of storage } \\
\text { Coefficient of permeability } \\
\text { Drawdown: } \\
\text { In pumped well at end of test } \\
\text { In observation well (computed) } \\
500 \text { feet distant: } \\
\text { After } 30 \text { days of pumping } \\
\text { After } 180 \text { days of pumping } \\
\text { feet.- } \\
\text { feet } 640 \text { feet distant: } \\
\text { After } 30 \text { days of pumping } \\
\text { After } 180 \text { days of pumping }\end{array}$ & $\begin{array}{r}1,675 \\
506,000 \\
80 \\
14,048 \\
23.8\end{array}$ & $\begin{array}{r}2,900 \\
28 \\
150 \\
1,700,000 \\
.0044 \\
17,500 \\
20\end{array}$ & $\begin{array}{r}125 \\
45 \\
3 \\
34,000 \\
.00095 \\
850 \\
\\
40\end{array}$ & $\begin{array}{r}600 \\
9 \\
19 \\
170,000 \\
.0054 \\
2,180 \\
(4)\end{array}$ & $\begin{array}{r}3480 \\
27.6 \\
53,900 \\
297 \\
17\end{array}$ & $\begin{array}{r}3660 \\
120,000 \\
.00098 \\
660\end{array}$ \\
\hline
\end{tabular}

Average from five pumping tests.

2 Artesian aquifer alone was pumped during first test. The casing was perforated in the unconfined-water zone for the second test, and pumping was from both aquifers.

Natural fiow of well.

4 Not measured, owing to failure of equipment.

When an expanding cone of depression around a pumped well reaches a hydraulic boundary, such as an impermeable bed (left side of figure 12), drawdown in the well increases and the cone of depression lowers more than it would if the boundary did not exist. The effect is similar to that of interference between wells (fig. 13). Conversely, if the cone of depression reaches a more permeable zone, or intercepts a source of water such as a stream or unlined canal (right side of figure 12), drawdown in the pumped well is less and the cone of depression lowers less than if the boundary did not exist. All these conditions, and many variations of them, would be encountered during pumping under the alternate plan, and would affect the efficiency of both water production and drainage by pumping.

\section{PGRFORMANCE OF WELLS}

Suitably constructed wells withdraw water in amounts near the capacity of aquifers to transmit and yield water, but improperly constructed wells produce less than the capacity of the aquifer. Hence the specific capacity of a well-that is, its yield in proportion to drawdown-represents the combined effects of aquifer and well characteristics. Poor wells do not necessarily indicate poor aquifers. The specific capacities of wells in the Boise Valley (table 20) range widely (from 8 to $450 \mathrm{gpm}$ per foot of drawdown), owing to the diversity of, aquifer characteristics and variations in well construction. Generalization of this information and other data indicates that wells in the 


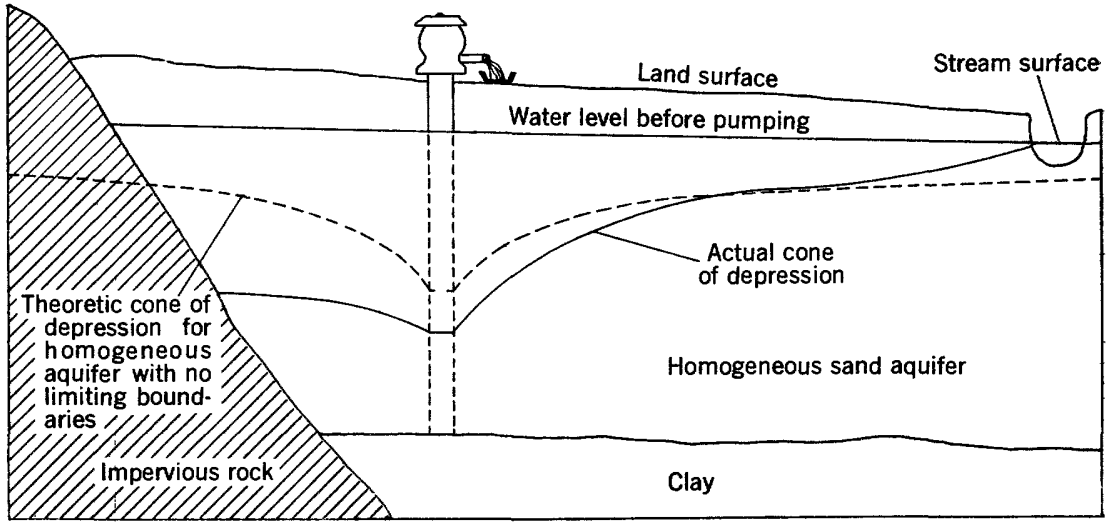

FIGURE 12.-Schematic sectional diagram illustrating the influence of impervious and recharge boundaries on the cone of depression around a pumped well.

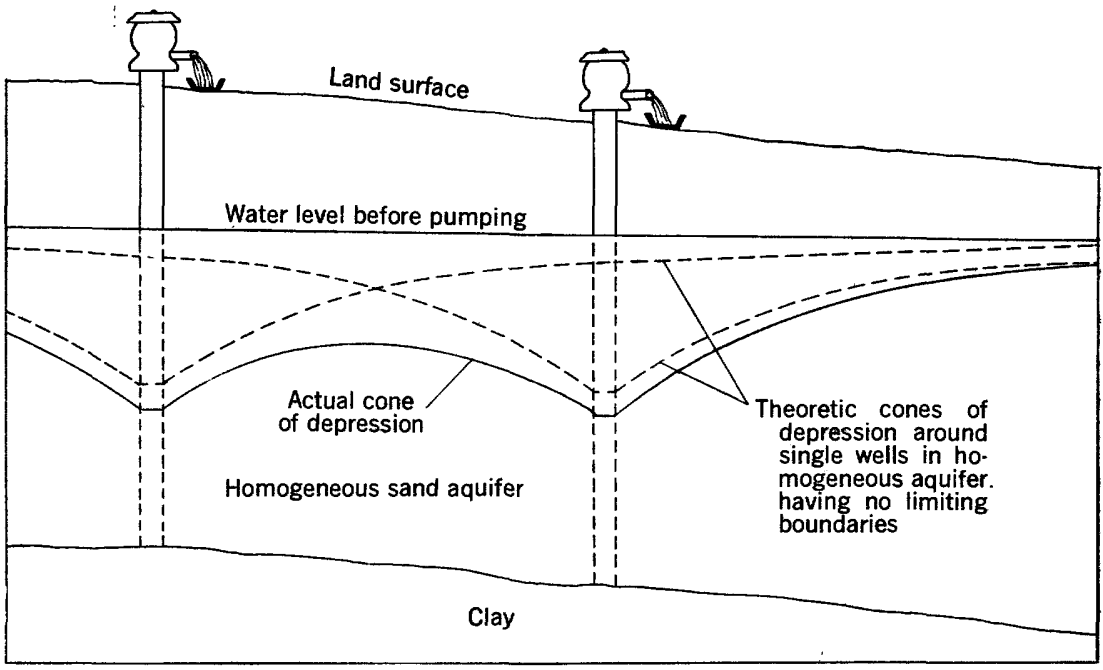

FIGURE 13.-Schematic sectional diagram illustrating the effects of interfering cones of depression around two pumped wells.

several ground-water districts would perform about as shown in table 21 if the aquifer were capable of supplying the water, and if well construction and development were suitable. 
TABLE 20.-Specific capacity of wells in the Boise Valley, in gallons a minute per foot of drawdown

[Computed from reported drawdown. Duration of pumping not known for most wells, but was generally longer than 24 hours]

\begin{tabular}{|c|c|c|c|}
\hline $\begin{array}{l}\text { Well No. and } \\
\text { location }\end{array}$ & Owner & Date of measurement & $\begin{array}{l}\text { Specific } \\
\text { capacity } \\
(\mathrm{gpm} / \mathrm{ft})\end{array}$ \\
\hline \multicolumn{4}{|c|}{ North-side district } \\
\hline 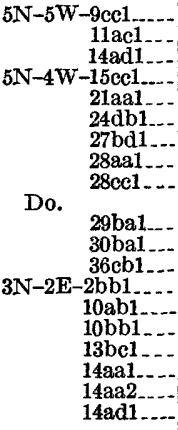 & $\begin{array}{l}\text { City of Parma } \\
\text { Boise Project Board of Control } \\
\text { do do do }\end{array}$ & $\begin{array}{l}\text { July } 1931 \\
\text { do }\end{array}$ & $\begin{array}{r}20 \\
50 \\
20 \\
27 \\
30 \\
19 \\
30 \\
27 \\
41 \\
45 \\
29 \\
35 \\
35 \\
18 \\
13 \\
9 \\
17 \\
12 \\
10 \\
450\end{array}$ \\
\hline
\end{tabular}

Wilder district

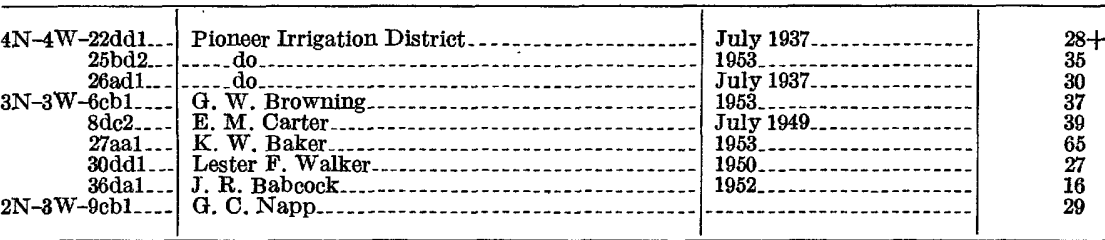

\begin{tabular}{|c|c|c|c|}
\hline & Nampa district & * & \\
\hline $4 \mathrm{~N}-3 \mathrm{~W}-22 \mathrm{ccl}$ & City of Caldwell & November 1950 & 26 \\
\hline 25da1 & Pioneer Irrigation District. & October 1953 & 50 \\
\hline $4 N-2 W-26 c a 1$ & 10 do & July 1937 & 48 \\
\hline $27 \mathrm{bal}$ & do & - do do & 32 \\
\hline $27 \mathrm{dc} 1$ & do........ & July 1939 & 12 \\
\hline $33 a b 1$ & do. & - do do & 32 \\
\hline $34 \mathrm{ed} 1$. & do & August 1939 & 41 \\
\hline $35 \mathrm{~cd} 1$ & 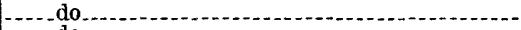 & July 1931 & 58 \\
\hline $36 \mathrm{ad} 1$ & ..... do & August 1939 & 39 \\
\hline $36 a c 1$ & 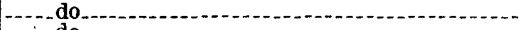 & July 1939 & 53 \\
\hline $36 c a 1$ & $\therefore$ do & August 1939 & 26 \\
\hline 4N-1W-30ed1 & 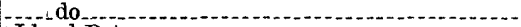 & - do do non & 21 \\
\hline $3 \mathrm{~N}-3 \mathrm{~W}-2 \mathrm{~cd} 3$ & ' Lloyd Peterson & $1953 \ldots$ & 60 \\
\hline $3 \mathrm{bb} 1$ & Pioneer Irrigation Distrlet & November 1953 & 131 \\
\hline 11 aal & J. G. Burback & $1953 \ldots$ & 85 \\
\hline $\begin{array}{l}\text { 11ad. } \\
\text { 11da. }\end{array}$ & $\begin{array}{l}\text { D. J. Herdt } \\
\text { Pioneer Irrigation District. }\end{array}$ & August $1953 \ldots$ & 34 \\
\hline $11 \mathrm{db} 2$ & $\begin{array}{l}\text { Floneer Irrigation District. } \\
\text { L. Walker }\end{array}$ & October 1953 & 100 \\
\hline $3 N-2 W-1 d b 1$ & Pioneer Irrigation Dlstrlct. & July 1931 & 41 \\
\hline 2cb1 & - ndo do.nen & $z^{-1}$ do & 58 \\
\hline $4 \mathrm{cb} 1$ & - 2 do $d 0$ & July 1939 & 42 \\
\hline $8 \mathrm{ccl}-$ & do do & Ootober 1953 & 39 \\
\hline $\begin{array}{l}\text { 9dd3 } \\
\text { 9dd4 }\end{array}$ & Amalgamated Sugar Co & February 1953............. & 52 \\
\hline 10ac1 & Pioneer Irrigation District. & August 1939 & $\begin{array}{l}30 \\
58\end{array}$ \\
\hline 11cd1. & 1 & July 1939 & 45 \\
\hline $11 \mathrm{~cd} 2$ & do & July 1931 & 66 \\
\hline $14 \mathrm{ccl}$ & . & August 1939 & 185 \\
\hline $15 \mathrm{dc1}$ & . do do & July 1939 & 67 \\
\hline 19aa1. & - & July 1931 & 52 \\
\hline $20 \mathrm{ac1}$ & Kawona & 1953 & 18 \\
\hline $21 \mathrm{ba2}$ & Pioneer Irrigation Dlstrict..................... & July 1931 & 63 \\
\hline $21 \mathrm{ba3}$ & John May & 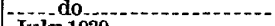 & 18 \\
\hline $\begin{array}{l}21 \mathrm{lbb1} \\
22 \mathrm{bb1}\end{array}$ & Pioneer Irrigation District............... & 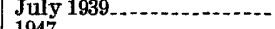 & 86 \\
\hline $3 N-1 W-7 b b 1$ & Ploneer Irrigatlon District & 1947 ctober $1953^{2}$ & \\
\hline $29 \mathrm{dd} 1$ & Freeman Cox & 1948 & $\begin{array}{l}\mathbf{0 2} \\
33\end{array}$ \\
\hline $2 N-1 \mathrm{~W}-7 \mathrm{bc4}$ & U. S. Bur. of Reclamation & September 1953 & 150 \\
\hline
\end{tabular}


TABLe 20.-Specific capacity of wells in the Boise Valley, in gallons a minute per foot of drawdown-Continued

\begin{tabular}{c|c|c|c}
\hline $\begin{array}{c}\text { Well No. and } \\
\text { location }\end{array}$ & Owner & Date of measurement & $\begin{array}{c}\text { Specefic } \\
\text { capacity } \\
\text { (gpm/tt) }\end{array}$ \\
\hline
\end{tabular}

Meridian district

\begin{tabular}{|c|c|c|c|}
\hline $\begin{array}{r}4 \mathrm{~N}-1 \mathrm{E}-27 \mathrm{Ad1} \\
3 \mathrm{~N}-1 \mathrm{E}-5 \mathrm{ab1} \\
3 \mathrm{~N}-2 \mathrm{E}-8 \mathrm{aa1} . \\
9 \mathrm{bd1} \\
15 \mathrm{bb1} \\
16 \mathrm{bb1} \\
25 \mathrm{bb1} \\
\end{array}$ & $\begin{array}{l}\text { Charles Silliman } \\
\text { U. S. Bur. of Reclamation } \\
\text { Boise Water Corp. }\end{array}$ & $\begin{array}{l}\text { November } 1953 \\
\text { February } 1947 \\
\text { May } 1951 \\
\text { November } 1947\end{array}$ & $\begin{array}{r}11 \\
19 \\
8 \\
18 \\
25 \\
73 \\
50\end{array}$ \\
\hline
\end{tabular}

Kuna district

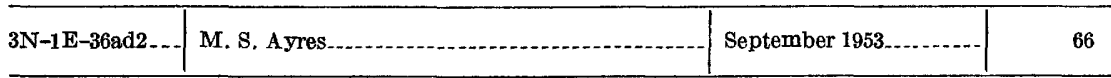

TABLE 21.-Estimated potential yield from pumped wells in the Boise Valley

\begin{tabular}{|c|c|c|c|c|c|c|c|c|c|c|}
\hline \multirow{3}{*}{ Ground-water district 1} & \multirow{3}{*}{$\begin{array}{l}\text { Average } \\
\text { specifie } \\
\text { capacity } \\
\text { (gpm/ft) }\end{array}$} & \multirow{3}{*}{$\begin{array}{l}\text { Approx- } \\
\text { imate } \\
\text { area } \\
\text { (sq mi) }\end{array}$} & \multicolumn{6}{|c|}{$\begin{array}{l}\text { Potential yield (cfs) with specified } \\
\text { drawdown }\end{array}$} & \multicolumn{2}{|c|}{$\begin{array}{c}\text { A verage potential } \\
\text { yield } 2 \\
\text { (acre-feet/year) }\end{array}$} \\
\hline & & & \multicolumn{3}{|c|}{ 30-foot draw down } & \multicolumn{3}{|c|}{ 50-foot draw down } & \multirow{2}{*}{$\begin{array}{l}\text { 30-foot } \\
\text { draw- } \\
\text { down }\end{array}$} & \multirow{2}{*}{$\begin{array}{l}\text { 50-foot } \\
\text { draw. } \\
\text { down }\end{array}$} \\
\hline & & & Min & $A \nabla$ & $\operatorname{Max}$ & Min & Av & $\operatorname{Max}$ & & \\
\hline $\begin{array}{l}\text { Meridian } \\
\text { Nampa....... } \\
\text { Wilder. } \\
\text { Kuna. }\end{array}$ & $\begin{array}{l}23 \\
58 \\
33 \\
40\end{array}$ & $\begin{array}{r}103 \\
120 \\
130 \\
92\end{array}$ & $\begin{array}{l}0.5 \\
0.8 \\
1.0 \\
0.7\end{array}$ & $\begin{array}{l}1.5 \\
3.9 \\
2.2 \\
2.7\end{array}$ & $\begin{array}{r}4.9 \\
10.0 \\
4.3 \\
4.7\end{array}$ & $\begin{array}{l}0.9 \\
1.3 \\
1.8 \\
1.1\end{array}$ & $\begin{array}{l}2.6 \\
6.7 \\
3.7 \\
4.5\end{array}$ & $\begin{array}{r}8.1 \\
16.7 \\
7.3 \\
7.8\end{array}$ & $\begin{array}{r}47,000 \\
138,000 \\
85,000 \\
73,000\end{array}$ & $\begin{array}{r}79,000 \\
230,000 \\
142,000 \\
121,000\end{array}$ \\
\hline Total . . & .......... & 445 & 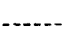 & & 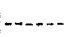 & ..... & - & & 343,000 & 572,000 \\
\hline
\end{tabular}

1 Districts correspond to those outlined on the map, plate 2

2 The "average potential yield" from the districts is a theoretic quantity which is based entirely on aquifer characteristics, ass'lming one well per square mile and a well-pumping season of about 5 mont s $^{2}$ each year. Recharge to the districts may or may not be sufficient that these potential yields could be obtained continuously.

The average performance of wells under the alternate plan probably would be somewhat better than that of existing wells in the Boise Valley, because many of the existing wells are of substandard design or were not fully developed. For example, most aquifers in the Boise Valley are poorly sorted sediments and for efficient water production they require well screens or gravel packing, or both. Few existing wells contain screens, and artificial gravel packing is uncommon. For natural gravel-packing the slot sizes in well screens ordinarily should pass about 75 percent of the grain sizes comprising the sediments adjacent to the screen. About the smallest slot size that can be used in the Boise Valley, however, is 0.03 inch; otherwise small mica flakes, which are abundant in most of the sediments, tend to pack around the screens and obstruct movement of water into the well. Accordingly, it is especially difficult adequately to screen and develop the finer grained sediments. 
Wells in silt and sand in the Boise Valley commonly require 50 to 60 hours of development; longer periods are necessary under some conditions. Very little development is required for wells constructed in the coarse sediments. Improved well construction and development would increase somewhat the unit construction cost of the alternate plan but probably would not increase the total cost because fewer units would be needed.

\section{GROUND-WATER MOVEMENT}

The source, route, and destination of ground water determine its availability. Water is not available if it moves only through or to areas where it cannot be practicably recovered. Some waterlogged areas cannot be reclaimed by relief drainage but can be helped by interception drainage-that is, by intercepting excess water before it reaches the area of concern. Thus the regional and local movements of ground water are intimately involved in the practicality of the alternate plan. The general directions of ground-water flow in the Boise Valley can be inferred from the water-table contour map (pl. 5). Movement is down-gradient at right angles to the contours. In local detail the form of the water table and the direction of ground-water movement doubtless are somewhat complicated. Such complications can neither be shown at the scale of plate 5 nor be resolved from available data.

A well-defined ground-water divide approximately follows the New York Canal near the southern margin of the irrigated area. North of Melba the divide leaves the canal and, passing about 2 miles north of Bowmont, extends northwestward near the south side of Lake Lowell The significance of this divide in the water budget of the valley has been shown (p. 47); briefly, about 20,000 acre-feet of ground-water recharge from the New York Canal escapes to the Mountain Home plateau south of the divide. Changes in the water regimen of the valley, especially by pumping adjacent to the canal as proposed in the alternate plan, might cause the divide to shift.

In a considerable area south of Lake Lowell the surface drainage is to the Boise River but the ground-water drainage is to the Snake. Thus, although ground-water recharge from all sources in that area probably is several hundred thousand acre-feet a year, it does not contribute to the supply in the Boise Valley.

North of the ground-water divide and south of the Boise River the general direction of ground-water movement is northwestward. Thus most ground water that originates south of the river and east of Caldwell moves northwestward through the exchange area. Very little of it passes through the Wilder ground-water district. 


\section{DEPTH TO WATER AND WATER-LEVEL CHANGFS}

The cost and depth of wells under the alternate plan would be determined by the depth to water and by aquifer characteristics (p. 54). The depth to water also would determine the amount of lowering necessary to effect drainage. The seasonal and yearly range and rate of water-level changes would determine the time when drainage pumping is necessary. Such tim e, if not simultaneous with the need for exchange water, would be a critical feature in the operation of the alternate plan.

The depth to water throughout the Boise Valley in 1953 is shown by plate 4 . Like plate 5 , the depth-to-water map is only approximate

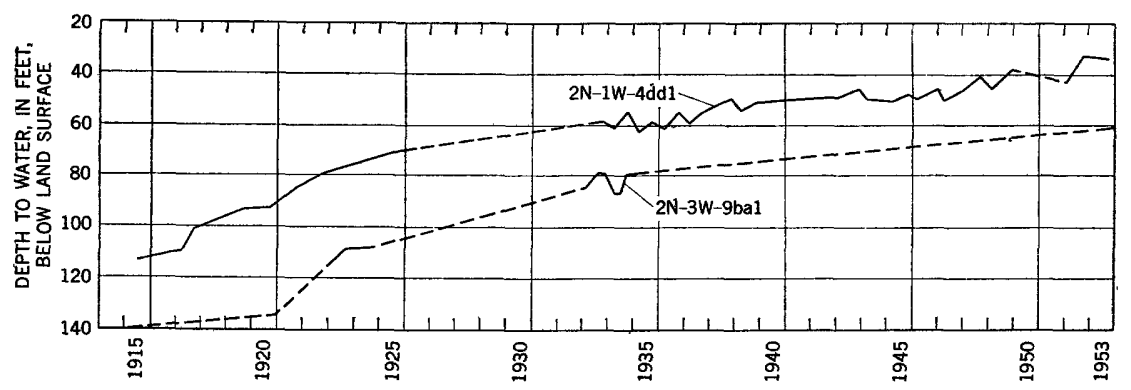

FIGURE 14.-Hydrographs of wells $2 \mathrm{~N}-3 \mathrm{~W}-9 \mathrm{ba1}$ and $2 \mathrm{~N}-1 \mathrm{~W}-4 \mathrm{dd} 1$ for the period 1915-53, showing long-term net rise of water table.

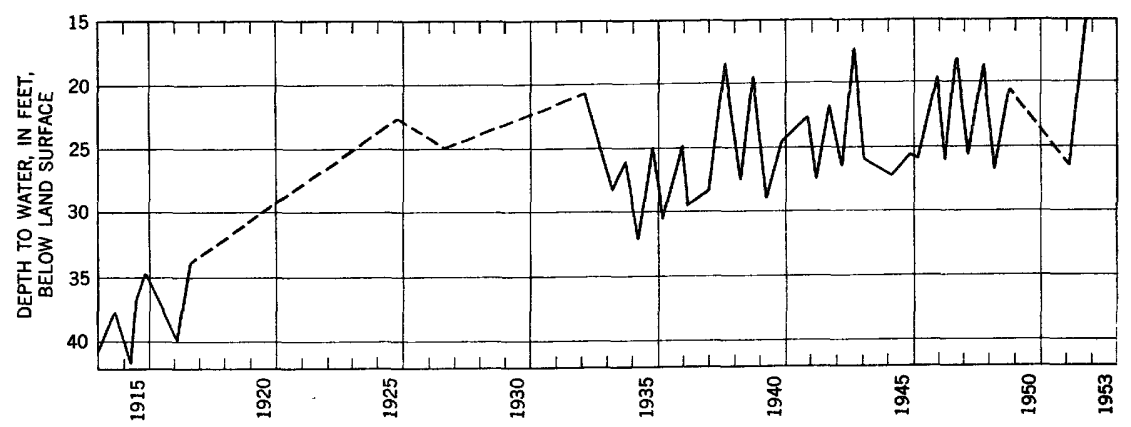

FigURE 15.-Hydrograph of well 4N-2E-31cc1 for the period 1914-52, showing seasonal and ather fluctuations and long-term net rise of water table.

because the maps were drawn on the basis of sparse data, and because the water table is changing constantly in form and position.

The maps showing the depth to water in 1914 and 1953 (pls. 6 and 4) suggest the large and widespread changes and trends in water levels during 40 years of irrigation. In much of the valley the trend has been upward for many years (figs. 3, 4, 14, and 15). Comparison of well hydrographs with precipitation graphs shows that the trend in water levels is not closely related to climatic changes (fig. 16), but 


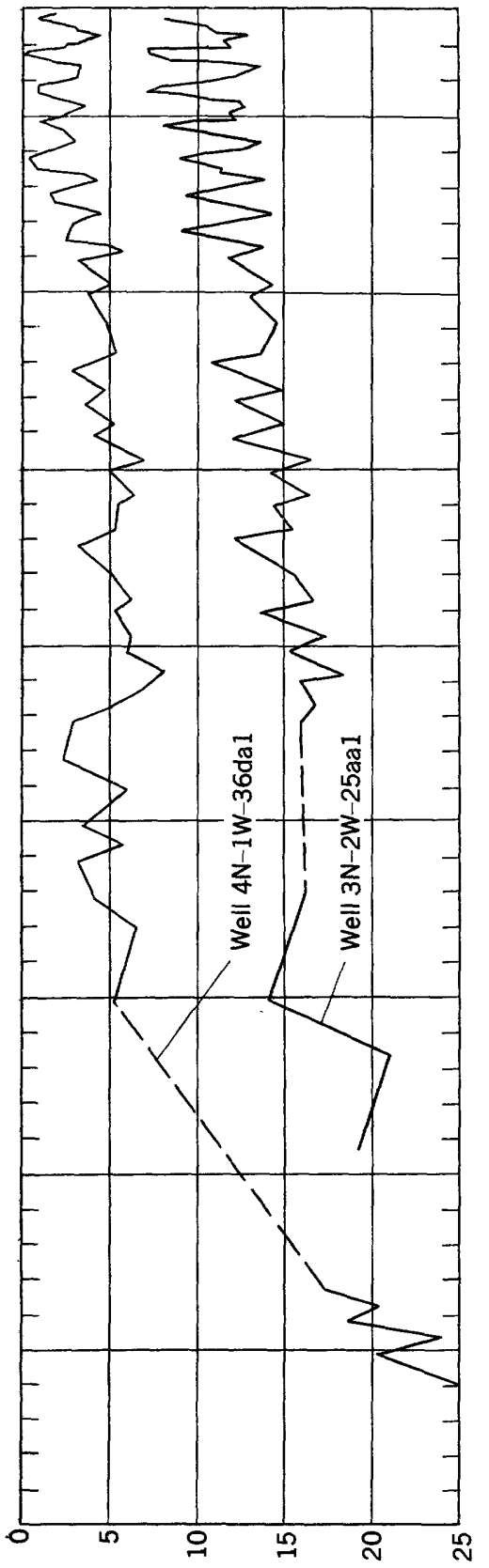

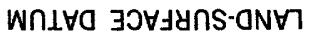

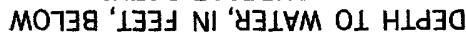

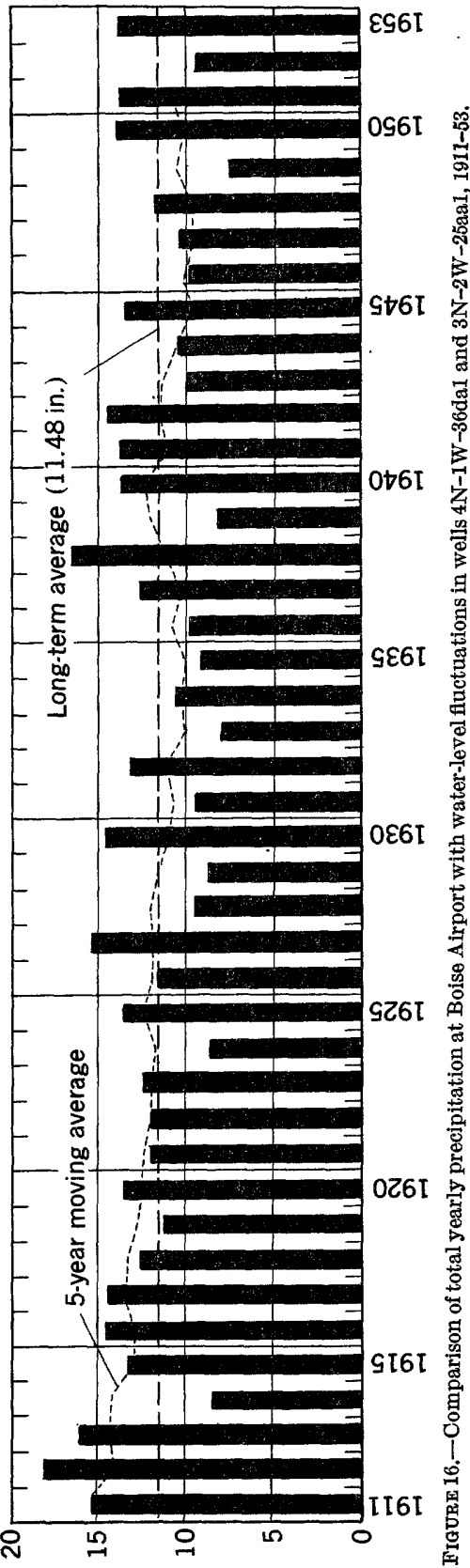

S $\exists$ HONI NI

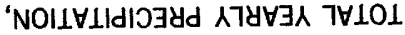


the relation to irrigation is obvious. An extreme example of the influence of irrigation practice is in the vicinity of Lake Lowell, where the water table rose 140 feet from 1912 to 1921 (fig. 3, well $4 \mathrm{~N}-4 \mathrm{~W}-$ $34 \mathrm{bc1}$ ). These water-level fluctuations and trends indicate changes in the amount of water in storage; hence, permanent storage has been increasing for many years. The graphs and maps illustrate also the continued seriousness of the drainage problem which the alternate plan proposes to solve.

The observed yearly range of fluctuation of the water table at many places in the valley is about 5 to 8 feet (figs. 16 and 17). Waterlevel fluctuations caused by current pumping can be interpreted to suggest the long-term effects of the more extensive and more intensive pumping under the alternate plan (table 18,), including interference when the cones of well influence overlap (fig. 13). These effects bear directly on the practicable location, arrangement, and spacing of wells under the plan. Interference causes reduced yield with given drawdown, or more drawdown and greater pumping lift at given rates of pumping. Minimum drawdown is desired during pumping to

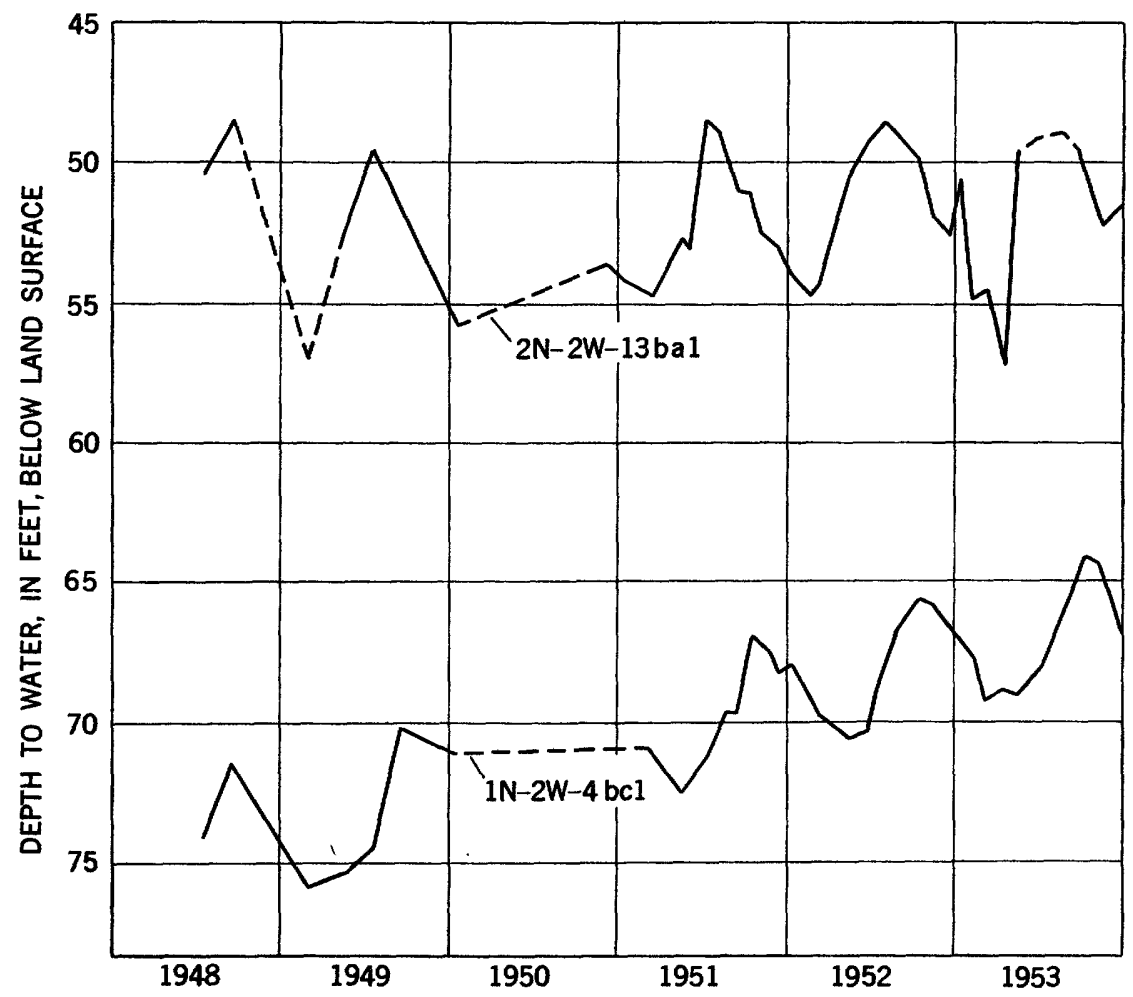

FigURE 17.-Seasonal water-level fluctuations in wells $2 \mathrm{~N}-2 \mathrm{~W}-13 \mathrm{bal}$ and $1 \mathrm{~N}-2 \mathrm{~W}-4 \mathrm{bc1}$. 
obtain usable water, but maximum drawdown may be necessary for effective drainage. At most places in the Boise Valley, a combination irrigation-and-drainage well cannot achieve maximum efficiency for both purposes, and may not achieve it for either. A critical concern in the alternate plan is whether reasonable efficiency can be achieved.

\section{EXAMPIES FROM TYPICAL AREAS}

Drainage problems in various degrees of seriousness and complexity exist in practically all irrigation districts in the Boise Valley. An essential feature of the alternate plan is its proposal to rectify this condition for 225,000 acres of land by changing the water-supply pattern. The field tests of the drainage and water-production efficiency of wells (table 19) were made in part to throw light on the problem involved.

\section{PIONEER IRRIGATION DISTRICT}

Early study of the performance of wells in the Pioneer Irrigation District by Kulp, 1931-41, seemed to indicate that in much of the district pumping held the water-table at a level about 4 to 10 feet lower than that to which it would have risen otherwise. Five of the wells in the district were among those tested in 1953 after the pumping season; the derived data are shown in table 19. The computed effects of pumping (table 18) do not indicate the combined effects of pumping All 5 wells simultaneously, nor do they show the combined effects of pumping the entire battery of about 30 wells. Obviously, however, the tests confirm that geologic conditions in the area are suitable for drainage by pumping. Individual wells have substantial influence at distances of more than half a mile, and sustained pumping gives sustained benefits.

In the Pioneer Irrigation District the chief aquifer is sand and gravel interbedded with clay. The wells are 66 to 232 feet deep and average 132 feet. Most wells tap more than one aquifer; some are artesian, but the principal yield probably is from unconfined water at relatively shallow depth. The depth to water in the wells is 3 to 23 feet at the beginning of the pumping season and about 27 feet at the close. The average depth to water in the district as a whole was about 10 feet in the summer of 1953 .

\section{ELLIS FARM}

The Harry Ellis farm is in sec. 7, T. 2 N., R. 1 W., in the NampaMeridian Irrigation District. Waterlogging on the farm is caused by upward leakage and capillary rise of artesian water through confining layers, and the average piezometric, or artesian-pressure, surface apparently is about 1 foot below the land surface during the irrigation season. Generally similar conditions are common in the Boise Valley. 
A block diagram (fig. 18) shows generalized subsurface conditions from the vicinity of the Ellis farm northward toward Nampa. Ground water is confined in basalt and gravel beneath hydraulically tight thin soil and caliche. Recharge to the aquifer possibly occurs locally, south and east of the Ellis farm. The western part of the Ellis farm is crossed by a shallow topographic trough in which waterlogging is chronic during the irrigation season. An open drain, 4 to 5 feet deep along the axis of the trough, does not dewater the soil effectively because the surface materials are fine-grained and the drain does not relieve the artesian pressure that causes the waterlogging. Six wells, 33 to 42 feet deep, were drilled in the floor of the drain in 1951 and 1952, with discharge openings 3 to 4 feet below the level of the adjacent land surface. The wells jointly yield several hundred gallons of water a minute by artesian flow. Waterlogging in adjacent land was materially relieved by these wells but was not eliminated.

A production-test well 103 feet deep, and two observation wells 107 and 103 feet deep, respectively, were drilled in this district in sec. 7, T. 2 N., R. $1 \mathrm{~W}$. Several adverse factors reduced the accuracy of the results from subsequent tests: The wells tap water in both gravel and basalt, materials having widely differing hydraulic characteristics; the Ridenbaugh canal and an open drain ditch, both containing a large amount of water during the test, are near the pumped well; flowing artesian wells in the vicinity were allowed to flow freely during the tests, because experimental antecedent shut-in of one well for 3 days caused prompt waterlogging in nearby fields. Canal, drain, and flowing wells affected water levels during the tests and the effects
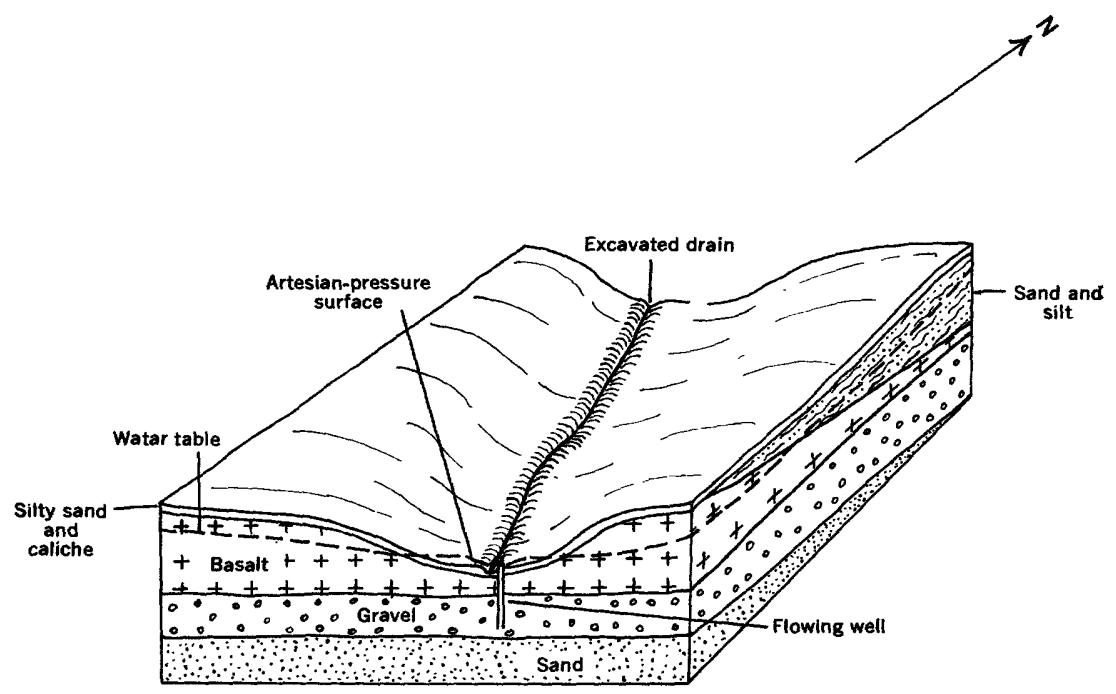

FIGURE 18.-Block diagram showing generalized subsurface conditions from the Ellis farm northward. 
could neither be eliminated nor be adequately estimated. Therefore the calculated coefficients (table 19) are unreal. Nevertheless, the effects of pumping that were computed from these coefficients are essentially the effects that could be anticipated in this area from pumping drainage wells (table 18).

During the test pumping the amount of water discharged by the nearby open drain dropped from 12.3 to $10.6 \mathrm{cfs}$ after $4 \frac{1}{2}$ hours, and to $10.2 \mathrm{cfs}$ after 22 hours. The rate of discharge from individual artesian wells ranged from 186 to $317 \mathrm{gpm}$ at the beginning of the test, but diminished until it was 146 to $238 \mathrm{gpm}$ at the end of the test. Relief drainage by pumping wells under conditions like those at the Ellis farm is feasible. The pumping lift would be low and the wells would have high specific capacities. Beyond the relief-drainage effect, a substantial amount of usable water can be obtained. In the test here cited the diminution of flow in the open drain and from flowing artesian wells was about 35 percent of the pumped-well discharge.

\section{USTICK-MERIDIAN AREA}

Between Meridian and Ustick, on Ustick road, is a waterlogged area on the Whitney terrace. To a depth of about 35 feet the waterlogged earth is clay, sand, and gravel; below are partly cemented silt and sand. The average depth to the regional water table is less than 10 feet. Temporary perched ground water causes saturation to the land surface each year during the irrigation season.

Test well $3 \mathrm{~N}-1 \mathrm{E}-5 \mathrm{ab1}, 123$ feet deep, was drilled through an upper water-bearing zone and an underlying nonpermeable zone, and bottomed in silt and sand containing water that rose to about 10 feet below the land surface. Casing was set to a depth of 81 feet to shut out the upper water, and a 25 -slot screen (slots 0.025 inch wide) was installed in the lower aquifer. A first test under these conditions was not promising so the casing was perforated to allow entry of the upper unconfined water from sand and gravel. Results of the two tests are shown in tables 18 and 19. A later and third test confirmed the second test.

The computed drawdown at distance from the pumped well is somewhat less for the second test, despite the greater pumping rate, because during the second test: drawdown in the pumped well was about 10 feet less than during the first test, back pressure against the "artesian" water by the water column in the well was correspondingly more, therefore the amount of water yielded by the "artesian" aquifer was less, and the two observation wells registered only the effects in the "artesian" aquifer. Obviously the hydraulic coefficients computed from the second test (table 19) are unreal, being correct for neither 
the lower nor the upper aquifer. They are included here to show that computations, even though based on measurements during a pumping test, can be entirely misleading if information about the subsurface geology and sources of water is lacking. During this test observations were made also in a nearby shallow domestic well that taps only the upper shallow aquifer. Pumping had no observable effect on that well.

Conditions at the Ustick road site illustrate other facts and conditions that are highly pertinent to drainage problems. Here, the water of the lower aquifer is believed to be artesian only in a loose sense of the word; when discovered by the drill it rose in the well, but only to about the level of the regional water table. The tight sediments between the upper and lower aquifers appear to be no more than a local separating layer, rather than an extensive confining bed. Casing seated in the separating layer probably excluded the shallow water from the well only during the early stage of the tests.

Separating layers such as that found in this well are common in alluvial sediments; ordinarily they are lenticular and feather out at varying lateral distances. Pumping from an underlying aquifer probably would not have a discernible effect on the water table until the cone of influence reached beyond the separating layer, and there would be no dewatering until that event occurred. During the pumping tests here summarized the behavior of water levels consistently indicated that a hydraulic-recharge boundary was reached, at an apparent distance of about 500 feet to the west, and that the cone of influence may have reached an edge of the separating layer in that direction. The tests apparently did not dewater enough of the aquifer to be noticeable at the domestic well, 1,300 feet distant. Later the test well was pumped for about 3 weeks, but, even so, effect in the domestic well was not detectable.

Pumped wells in the Ustick-Meridian area, where the geologic conditions resemble those at the test site, would provide some drainage benefit. Pumping artesian aquifers would lower pressure and reduce upward leakage through imperfect confining beds. Pumping unconfined water might dewater appreciable amounts of saturated materials, but wells would be less effective and less productive than in areas like the Pioneer Irrigation District and the Ellis farm. Moreover, well construction and development would be more costly. The cost of pumping, per unit of water produced, would be relatively high because of the relatively lower specific capacities of wells.

In much of the Ustick-Meridian area very shallow ground water is perched intermittently on silt, clay, and caliche. Recharge seems to be largely or entirely by local infiltration of irrigation water. The perched water table or its capillary fringe are at or near the land 
surface and much of the land is suitable only for pasture. Open surface drains in these areas are unsatisfactory because the saturated material is very fine grained and has a low specific yield. Wells like the one tested would not withdraw the perched water. Wells that penetrated only the thin perched zones of saturation would be ineffective because those zones are low in permeability and can not afford adequate entrance area at a well screen.

Under conditions like those in the Ustick-Meridian area it would be difficult to drain the land and the water production would be relatively inefficient. Pumping from the principal aquifers, either unconfined or artesian, would alleviate waterlogging somewhat, except where there is perched ground water. The principal hope for such areas is general relief by ground-water pumping, plus extremely prudent use of irrigation water to minimize recharge to perched aquifers.

\section{RAGLE ISLAND}

Eagle Island covers about 5 square miles in the Boise River about half a mile south of Eagle in the east-central part of T. 4N., R. 1 W. (pl. 2). 'Tests of wells on the island clearly show the characteristics of artesian aquifers in the Idaho formation at depths down to a few hundred feet. About 50 flowing artesian wells provide water for stock and domestic use, irrigation, and a trout hatchery of the Idaho Department of Fish and Game. Most of the larger wells produce for irrigation, but the largest two produce for the fish hatchery. The discharge rates of domestic and irrigation wells range from 2 to 280 $\mathrm{gpm}$ and average less than $100 \mathrm{gpm}$. The estimated aggregate yield of seven wells at the hatchery in 1951 was about $2,000 \mathrm{gpm}$, or about 20 percent of the total ground-water withdrawals on the island.

The chief artesian aquifers developed on Eagle Island are beds of sand and gravel between confining layers of clay and silt. At the hatchery such aquifers occur at depth intervals of about 80 to 125, 155 to 205 , and 230 to 412 feet. Most wells tap the middle aquifer The shut-in pressure ranges from 3 to 27 feet above the land surface, being least in the uppermost aquifer and progressively greater 10 , deeper aquifers.

Most of the wells have open-end casing, and silting of the lig air part of the casing has caused the yield of many wells to diminish steadily.

The advantage of proper construction and development is iłtistragtraged

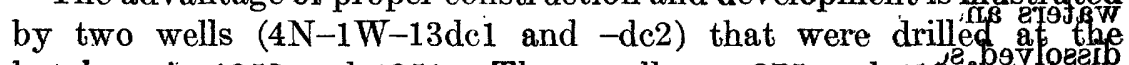
hatchery in 1950 and 1951 . These wells are 375 and $411^{2}$ f fet deep respectiviely. During drilling the upper aquifer yielded $30 \mathrm{gms} \mathrm{gmg}$ artesian flow and the middle aquifer yielded about $800^{5} l_{0 m}$ upper aquifer was cased out of both wells; one finished well taps mqit 
middle and lower aquifers and the other taps only the lower. Each well was finished with an 8-inch screen and a natural gravel pack was formed by development.

During the development work the aggregate natural flow of the two wells increased from 792 to $1,140 \mathrm{gpm}$, exceeding the combined flow of the five older open-end wells at the hatchery. The two developed wells were test pumped at rates up to $1,500 \mathrm{gpm}$. The hydraulic coefficients are shown in table 19, and the calculated timedistance drawdowns are shown in table 18.

\section{SUITABIITTY OF THE WATER FOR IRRIGATION}

GENERAL CEWMICAL FEATURES AND TEMPERATURE

The water-exchange proposals of the alternate plan would alter the chemical character of the water supply of a large acreage because most ground water in the Boise Valley has a higher mineral content than the basic surface-water supply. Although the ground water at most places would be diluted with surface water, some lands might receive a preponderance of ground water. Hence the chemical suitability of the ground water for irrigation is considered here.

Little is known about the quality of ground water on the Mountain Home plateau. Inasmuch as most of or all farm and domestic supplies in that part of the area covered by the alternate plan presumably would be ground water, their potential quality merits investigation. This is especially true because, locally in southwestern Idaho, ground water associated with certain rocks contains fluoride in amounts sufficient to cause mottling of the tooth enamel of children who use the water during the period of calcification of the permanent teeth (Dean, 1936).

Available ground-water analyses are contained in table 25, at the end of this section. Samples that are represented graphically on plate 7 are thought to represent the principal chemical types of ground water in the Boise Valley, because the samples were from waterbearing materials of a wide variety in a considerable range of depths. Analyses of surface-water samples, which are included for comparison (see pl. 7 and table 24), represent seasonal and geographic variations in the chemical quality of river and canal water.

The variation in chemical characteristics shown by the available analyses is summarized in table 22 and in figure 19 and plate 7 , separately for ground water and for surface water. Both the ground waters and the surface waters range moderately in concentration of dissolved solids, the range for ground waters being from 69 to 1,040 ppm and that for surface waters being from 51 to $788 \mathrm{ppm}$, among those analyzed. Both categories range substantially in composition, from calcium-magnesium bicarbonate waters to sodium bicarbonate 


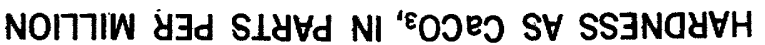

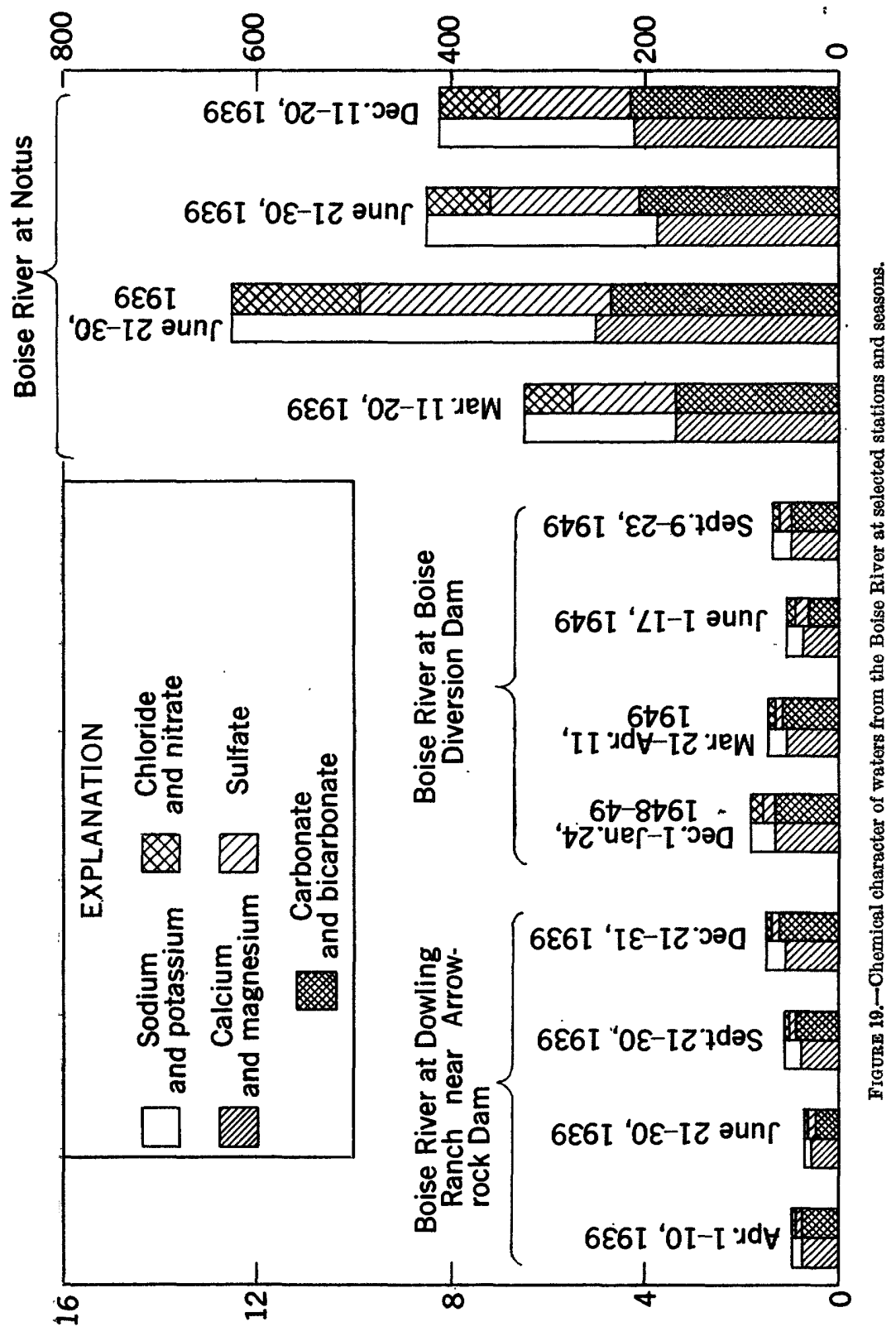

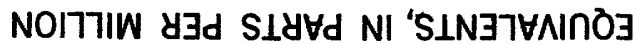


and sodium bicarbonate-sulfate waters. In general, sodium concentration and percent sodium increase toward the west, or downstream.

TABLD 22.-Summary of chemical analyses of water

[Chemical constituents in parts per million]

\begin{tabular}{|c|c|c|c|c|}
\hline \multirow{2}{*}{ Constituent or property } & \multicolumn{2}{|c|}{ Surface water } & \multicolumn{2}{|c|}{ Ground water } \\
\hline & Maximam & Minimum & Maximum & Minimum \\
\hline 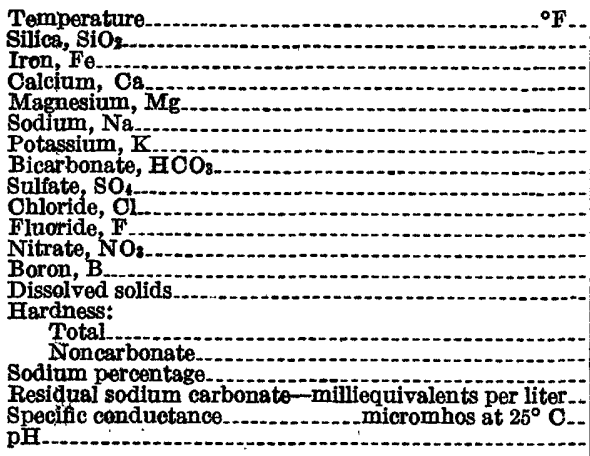 & \begin{tabular}{|l}
75 \\
35 \\
61 \\
25 \\
193 \\
118 \\
291 \\
244 \\
93 \\
.6 \\
5.9 \\
$788^{.04}$ \\
251 \\
31 \\
60 \\
1,160 \\
8.6
\end{tabular} & $\begin{array}{c}{ }^{59} \\
12.00 \\
7.9 \\
.3 \\
3.7 \\
1.6 \\
36 \\
2.7 \\
.8 \\
.2 \\
.3 \\
.02 \\
51 \\
21 \\
14 \\
67 \\
6.9\end{array}$ & $\begin{array}{c}80 \\
93 \\
1.4 \\
87 \\
41 \\
250 \\
12 \\
476 \\
309 \\
97 \\
7.0 \\
41 \\
1,040 \\
.36 \\
386 \\
214 \\
82 \\
4.24 \\
1,510 \\
8.8\end{array}$ & $\begin{array}{c}52 \\
14 \\
0 \\
7.9 \\
.3 \\
27.5 \\
20 \\
53.7 \\
.8 \\
0.2 \\
0^{.2} \\
69^{.02} \\
24 \\
0 \\
5 \\
0 \\
112 \\
6.6\end{array}$ \\
\hline
\end{tabular}

1 The range in calculated content of sodium and potassium is from 3 to $172 \mathrm{ppm}$.

2 The minimum calculated content of sodium and potassium is $1 \mathrm{ppm}$.

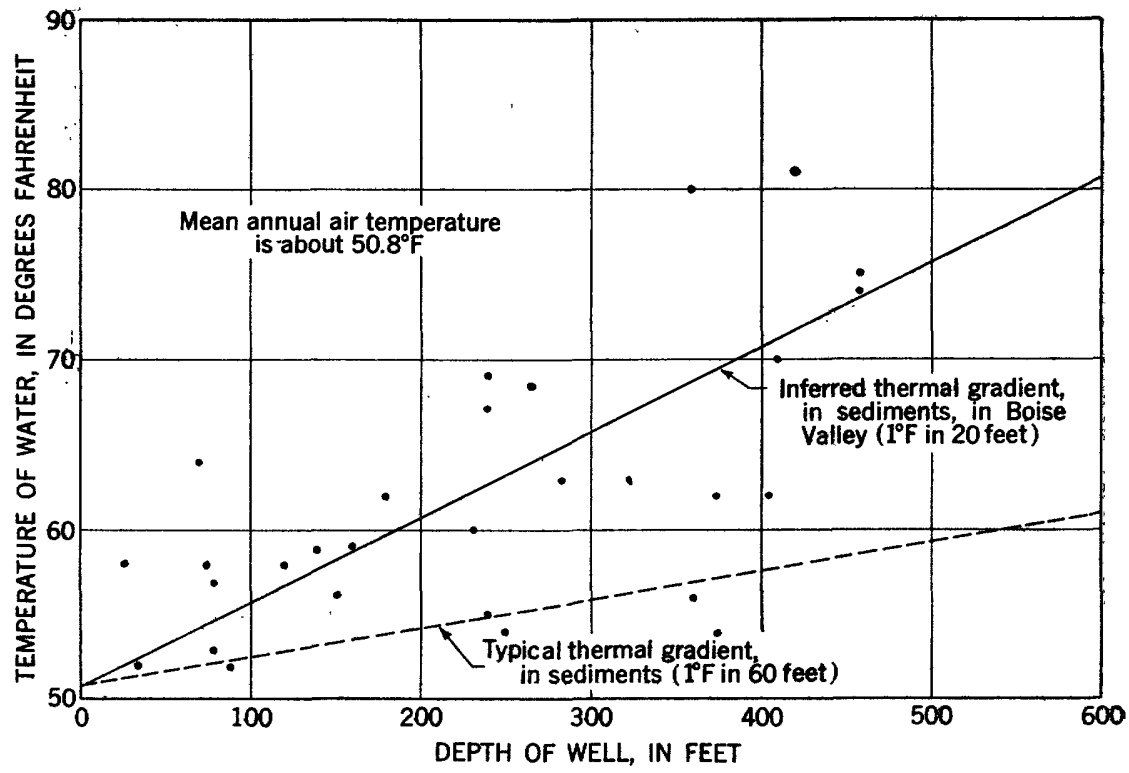

Figure 20.-Variations of ground-water temperature with depth, and comparison to typical and inferred thermal gradients. 
The temperature of water from 93 wells in the Boise Valley ranged from $52^{\circ}$ to $83^{\circ} \mathrm{F}$. Owing to the natural increase of temperature downward in the earth's crust, water from deep sources tends to be warmer than that from shallow sources. For sedimentary materials in general, the temperature gradient commonly is about $1^{\circ} \mathrm{F}$ for each 50 to 100 feet of depth. In the sediments in the Boise Valley the gradient is variable but seems to average about $1^{\circ} \mathrm{F}$ for each 20 feet of depth (fig. 20). Along the north side of the valley lowland, near the foothills, deep artesian wells tap water whose temperature is as much as $122^{\circ} \mathrm{F}$. Even warmer water is reported in wells within the foothills area. Thus some ground water in the valley obviously is too warm for agricultural use directly from wells.

Water leaking from the warm wells and aquifers raises the water temperature in shallower zones. At most places, however, water having temperatures detrimental to agricultural use occurs at depths greater than are likely to be reached by wells that would be drilled under the alternate plan, or in areas distant from that involved in the plan.

\section{CLASBIFICATION OF THE WATER FOR IRRIGATTON USE}

PRINCIPAL FACTORS

The chemical suitability of water for irrigation depends chiefly on four factors: the amount of dissolved solids; the amount of sodium in proportion to calcium and magnesium; the ratio of bicarbonate to calcium and magnesium; and the concentration of boron. Assuming ordinary amounts of boron and low concentrations of bicarbonate relative to calcium and magnesium, the dissolved-solids content and the proportionate content of sodium are prime controlling factors. Specific conductance, a measure of the electrical conductivity of water, is useful in the evaluation of irrigation water because it is an approximate index to the concentration of dissolved solids. In some classification systems it is taken as a general index of suitability. Also, where galvanic conditions exist, highly conductive water speeds the process of electrolytic corrosion in well casings and pipelines.

Among the four principal factors, the amount of dissolved sodium in proportion to the amount of calcium and magnesium largely determines the suitability of water for irrigation. In favorable proportions, calcium and magnesium maintain good tilth and structure (texture) in soil. Calcium, one of the most common alkaline-earth elements, is readily soluble in slightly acidic water and is relatively abundant in all waters of the Boise Valley. In contrast, a high proportion of sodium in irrigation water tends to destroy the friable, granular condition of soil by dispersing the mineral particles, causing 


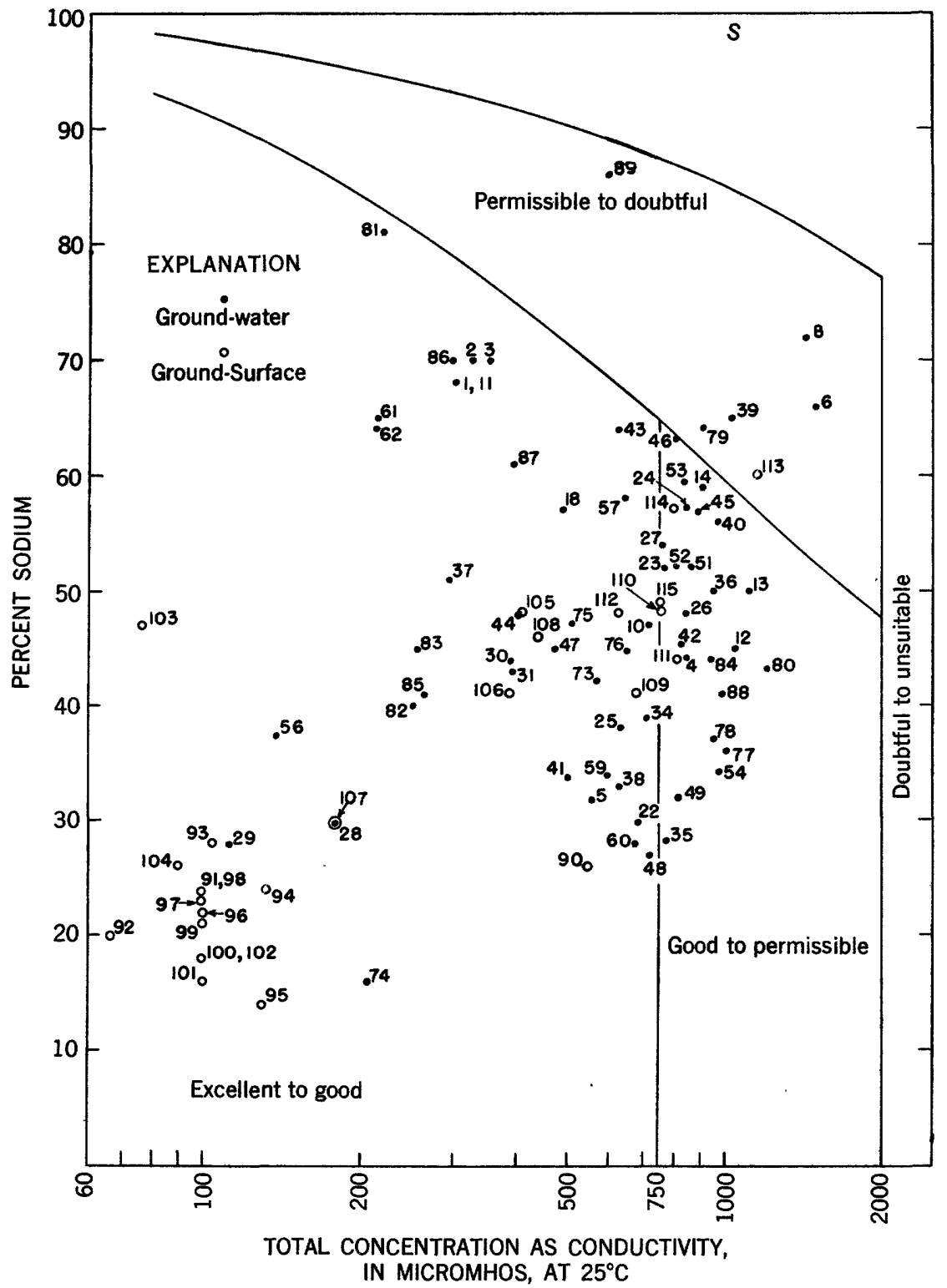

FIGURE 21.-Classification of Boise Valley waters according to percent sodium and concentration (modified after Wilcox). Numbers refer to locations in tables 22, 23, and 24. Solid circles indicate ground water, open circles, surface water.

the soil to become impermeable. Excessive bicarbonate tends to aggravate the effects of a high sodium proportion (Eaton, 1950). Soil thus damaged will not drain freely once it is wetted, even where it is above the water table. Some soil types of the Boise Valley and 
the Mountain Home-plateau are susceptible to damage by sodium bicarbonate. (In many chemical analyses potassium and sodium, which have somewhat similar chemical properties, have been reported together as a computed value as sodium. In most natural water the amount of potassium is relatively small.)

Three criteria for evaluating the sodium hazard ("alkali" hazard) of irrigation waters are widely used. These are the percent sodium (Wilcox, 1948), the sodium-adsorption ratio (U. S. Salinity Laboratory Staff, 1954), and the residual sodium carbonate (Eaton, 1950). No one of these is an absolute criterion by itself, because the suitability of a water is influenced in some degree both by soil-drainage conditions and by water-management and soil-amendment practices.

\section{CLASSTFICATION ACCORDING TO PERCENT SODIOM}

The percent sodium is the percentage ratio of the milliequivalents per liter of $\mathrm{Na}+$ to the sum of the milliequivalents per liter of $\mathrm{Na}+$, $\mathrm{K}+, \mathrm{Ca}++$, and $\mathrm{Mg}++$. The percentage ratio is then plotted against electrical conductivity on a standard diagram that defines the suitability classes. From the available analyses of Boise Valley waters, values of percent sodium are given in table 23 and the irrigation-suitability classification is derived on figure 21 .

According to percent sodium most of the 89 analyzed samples of Boise Valley ground water are excellent to good, a few are permissible to doubtful, and none would be unsuitable (fig. 21). By the same criterion, the suitability of the surface waters for irrigation generally is slightly superior to that of the ground waters.

\section{TABLE 23.-Classification of irrigation waters in Boise Valley}

Letter symbols indicate suitability for irrigation as follows:

Percent sodium: $E$, excellent; $G$, good; $P$, permissible; $D$, doubtful

Sodium-adsorption-ratio classification: Salinity hazard- $\mathrm{C}_{1}$, low; $\mathrm{C}_{2}$, medium; $\mathrm{C}_{3}$, high. Sodium or

"alkali" hazard- $\mathrm{S}_{1}$, low; $\mathrm{S}_{2}$, medium.

Residual sodium carbonate classification: 8 , probably safe; $M$, marginal; $U$, unsuitable.

' [From analyses by U. S. Geological Survey, U. S. Bureau of Reclamation, Idaho Department of Public Health, and University of Idaho Agricultural Experiment Station]

\begin{tabular}{|c|c|c|c|c|c|c|c|c|}
\hline \multirow[b]{2}{*}{$\underset{\text { Sample }}{\text { No. }}$} & \multirow[b]{2}{*}{ Well or spring No. or } & \multirow[b]{2}{*}{ Date of collection } & \multicolumn{2}{|c|}{ Percent sodium } & \multicolumn{2}{|c|}{$\begin{array}{c}\text { Sodium adsorp- } \\
\text { tion ratio (sa- } \\
\text { linity-sodium } \\
\text { hazard) }\end{array}$} & \multicolumn{2}{|c|}{$\begin{array}{l}\text { Residual } \\
\mathrm{Na}_{2} \mathrm{CO}_{3}\end{array}$} \\
\hline & & & Percent & $\begin{array}{c}\text { Suit- } \\
\text { ability } \\
\text { symbol }\end{array}$ & $\begin{array}{l}\text { Milli- } \\
\text { equiv- } \\
\text { alents } \\
\text { per } \\
\text { liter }\end{array}$ & $\begin{array}{c}\text { Suit- } \\
\text { ability } \\
\text { symbol }\end{array}$ & $\begin{array}{l}\text { Milli- } \\
\text { equiv- } \\
\text { alents } \\
\text { per } \\
\text { liter }\end{array}$ & $\begin{array}{l}\text { Suit- } \\
\text { ability } \\
\text { symbol }\end{array}$ \\
\hline
\end{tabular}

Ground water

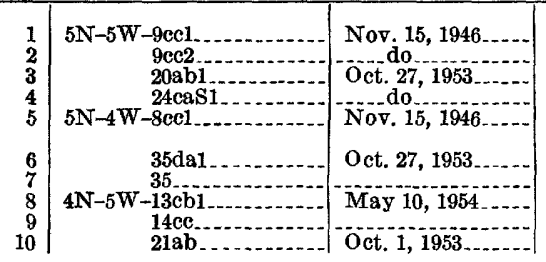

\begin{tabular}{l|l}
68 & $G$ \\
70 & $G$ \\
70 & $G$ \\
44 & $G$ \\
32 & $G$ \\
66 & D \\
50 & G \\
72 & D \\
51 & G \\
47 & G
\end{tabular}

3. 13
3.32
3. 57
2.53
1.33

6.53
1.19
7.45
2.37
2.74

$\mathrm{C}_{2} \mathrm{~S}_{1}$
$\mathrm{C}_{2} \mathrm{~S}_{1}$
$\mathrm{C}_{2} \mathrm{~S}_{1}$
$\mathrm{C}_{3} \mathrm{~S}_{1}$
$\mathrm{C}_{2} \mathrm{~S}_{1}$

$\mathrm{C}_{3} \mathrm{~S}_{2}$
$\mathrm{C}_{2} \mathrm{~S}_{1}$
$\mathrm{C}_{3} \mathrm{~S}_{2}$
$\mathrm{C}_{2} \mathrm{~S}_{1}$
$\mathrm{C}_{2} \mathrm{~S}_{1}$


TABLE 23.-Classification of irrigation waters in Boise Valley-Continued

\begin{tabular}{|c|c|c|c|c|c|c|c|c|}
\hline \multirow{2}{*}{$\begin{array}{l}\text { Sample } \\
\text { No. }\end{array}$} & \multirow{2}{*}{$\begin{array}{l}\text { Well or sprimg No. or } \\
\text { location }\end{array}$} & \multirow{2}{*}{ Date of collection. } & \multicolumn{2}{|c|}{ Percent sodium } & \multicolumn{2}{|c|}{$\begin{array}{l}\text { Sodium adsorp- } \\
\text { tion ratio (sa- } \\
\text { linity-sodium } \\
\text { hazard) }\end{array}$} & \multicolumn{2}{|c|}{$\begin{array}{l}\text { Residual } \\
\mathrm{Na}_{2} \mathrm{CO}_{3}\end{array}$} \\
\hline & & & Percent & $\begin{array}{l}\text { Suit- } \\
\text { ability } \\
\text { symbol }\end{array}$ & $\begin{array}{l}\text { Mijli- } \\
\text { equiv- } \\
\text { alents } \\
\text { per } \\
\text { liter }\end{array}$ & $\begin{array}{l}\text { Suit- } \\
\text { ability } \\
\text { symbol }\end{array}$ & $\begin{array}{l}\text { Milli- } \\
\text { equiv- } \\
\text { alents } \\
\text { per } \\
\text { liter }\end{array}$ & $\begin{array}{l}\text { Sult- } \\
\text { ability } \\
\text { symbol }\end{array}$ \\
\hline
\end{tabular}

Ground water-Continued

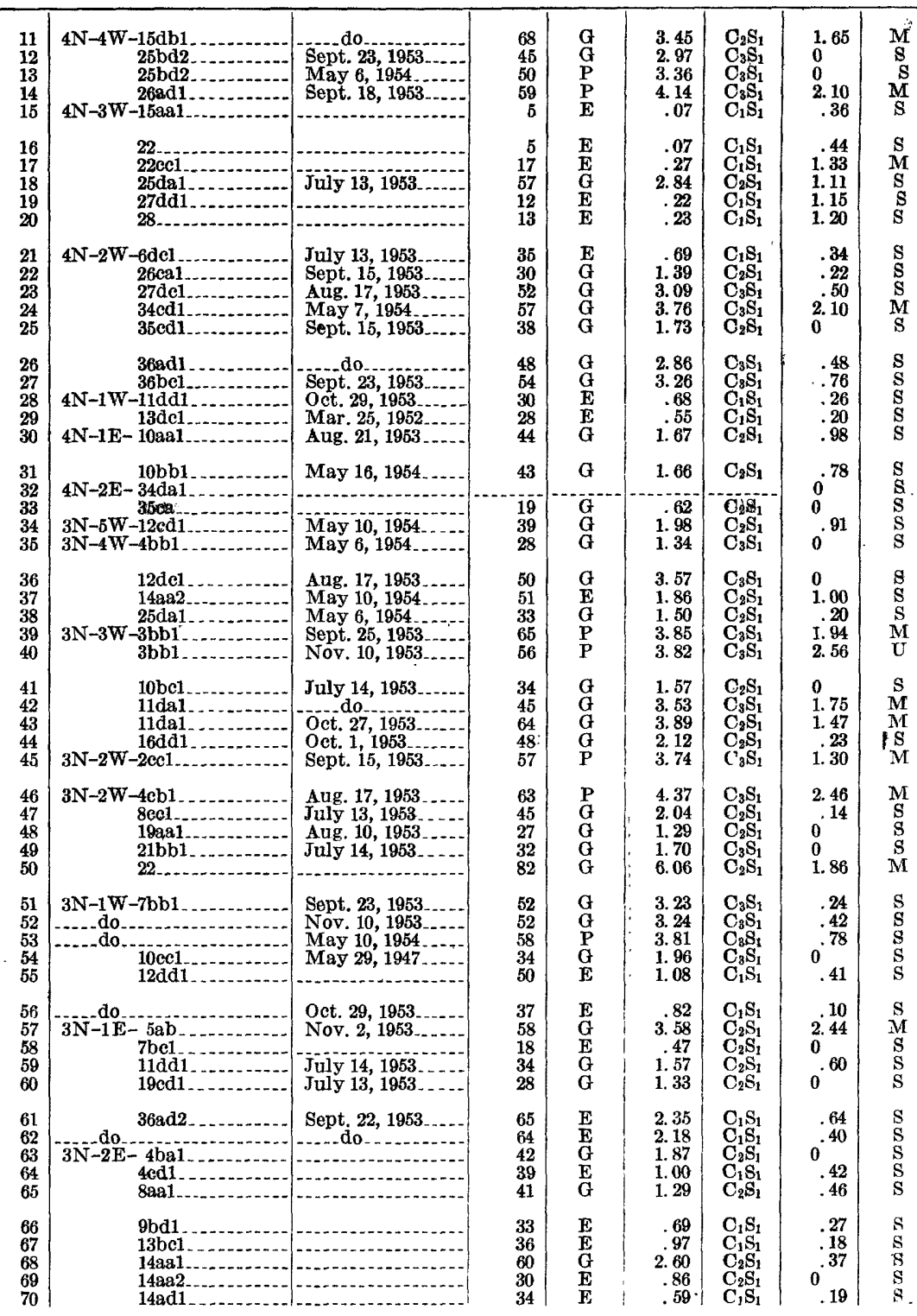


TABLE 23.-Classification of irrigation waters in Boise Valley-Continued

\begin{tabular}{|c|c|c|c|c|c|c|c|c|}
\hline \multirow[b]{2}{*}{$\begin{array}{l}\text { Sample } \\
\text { No. }\end{array}$} & \multirow[b]{2}{*}{$\begin{array}{c}\text { Well or spring No. or } \\
\text { location }\end{array}$} & \multirow[b]{2}{*}{ Date of collection } & \multicolumn{2}{|c|}{ Percent sodium } & \multicolumn{2}{|c|}{$\begin{array}{l}\text { Sodium adsorp- } \\
\text { tion ratio (sa- } \\
\text { linity-sodium } \\
\text { hazard) }\end{array}$} & \multicolumn{2}{|c|}{$\begin{array}{l}\text { Residual } \\
\mathrm{Na}_{9} \mathrm{CO}_{3}\end{array}$} \\
\hline & & & Percen & $\begin{array}{c}\text { Suit- } \\
\text { ability } \\
\text { symbol }\end{array}$ & $\begin{array}{l}\text { Milli- } \\
\text { equiv- } \\
\text { alents } \\
\text { per } \\
\text { liter }\end{array}$ & $\begin{array}{l}\text { Suit- } \\
\text { ability } \\
\text { symbol }\end{array}$ & $\begin{array}{l}\text { Milli- } \\
\text { equiv- } \\
\text { alents } \\
\text { per } \\
\text { liter }\end{array}$ & $\begin{array}{l}\text { Suit- } \\
\text { ability } \\
\text { symbol }\end{array}$ \\
\hline
\end{tabular}

Ground water

\begin{tabular}{|c|c|c|c|c|c|c|c|c|}
\hline $\begin{array}{l}71 \\
72 \\
73 \\
74 \\
75\end{array}$ & $\begin{array}{r}3 \mathrm{~N}-2 \mathrm{E}-15 \mathrm{bb} 1 \\
15 \mathrm{dd} 1 \\
20 \mathrm{bb1} 1 \\
25 \mathrm{bb1} \ldots \\
2 \mathrm{~N}-3 \mathrm{~W}-22 \mathrm{cb} 1 \ldots\end{array}$ & $\begin{array}{l}\text { Sept. 22, 1953... } \\
\text { Oct. } 30,1953 \\
\text { Nov. 10, 1953... } \\
\text { May 6, 1954 }\end{array}$ & $\begin{array}{l}31 \\
48 \\
42 \\
16 \\
47\end{array}$ & $\begin{array}{l}\mathbf{E} \\
\mathbf{E} \\
\mathbf{G} \\
\mathbf{E} \\
\mathbf{G}\end{array}$ & $\begin{array}{r}.92 \\
1.22 \\
2.01 \\
.38 \\
2.13\end{array}$ & $\begin{array}{l}\mathrm{C}_{2} \mathrm{~S}_{1} \\
\mathrm{C}_{1} \mathrm{~S}_{1} \\
\mathrm{C}_{2} \mathrm{~S}_{1} \\
\mathrm{C}_{1} \mathrm{~S}_{1} \\
\mathrm{C}_{2} \mathrm{~S}_{1}\end{array}$ & $\begin{array}{r}.26 \\
.45 \\
.78 \\
0 \\
1.07\end{array}$ & $\begin{array}{l}\mathbf{S} \\
\mathbf{S} \\
\mathbf{S} \\
\mathbf{S} \\
\mathbf{S}\end{array}$ \\
\hline $\begin{array}{l}76 \\
77 \\
78 \\
79 \\
80\end{array}$ & $\begin{array}{r}2 \mathrm{~N}-1 \mathrm{~W}-7 \mathrm{bb} 1 \ldots \\
7 \mathrm{bc4} \\
18 \mathrm{bb} 1 \\
18 \mathrm{~b} 1\end{array}$ & $\begin{array}{l}\text { Sept. } 15,1953 \ldots \\
\text { Sept. } 25,1953 \ldots \\
\text { May } 6,1954 \ldots \\
\text { May } 10,1954 \ldots\end{array}$ & $\begin{array}{l}46 \\
36 \\
37 \\
64 \\
43\end{array}$ & $\begin{array}{l}\mathrm{G} \\
\mathrm{G} \\
\mathrm{G} \\
\stackrel{\mathbf{P}}{\mathbf{P}}\end{array}$ & $\begin{array}{l}\text { 2. } 40 \\
2.21 \\
2.19 \\
\text { 4. } 73 \\
2.99\end{array}$ & $\begin{array}{l}\mathrm{C}_{2} \mathrm{~S}_{1} \\
\mathrm{C}_{3} \mathrm{~S}_{1} \\
\mathrm{C}_{3} \mathrm{~S}_{1} \\
\mathrm{C}_{3} \mathrm{~S}_{1} \\
\mathrm{C}_{3} \mathrm{~S}_{1}\end{array}$ & $\begin{array}{l}0.81 \\
0 \\
1.91 \\
0\end{array}$ & $\begin{array}{c}\mathrm{S} \\
\mathbf{S} \\
\mathrm{S} \\
\mathrm{M} \\
\mathrm{S}\end{array}$ \\
\hline $\begin{array}{l}81 \\
82 \\
83 \\
84 \\
85\end{array}$ & $\begin{array}{r}23 d d 1 \\
2 N-3 \mathrm{E}-7 \mathrm{~cd} 2 \\
1 \mathrm{~N}-2 \mathrm{~W}-3 \mathrm{cb1} \\
16 \mathrm{cb1} \ldots \\
1 \mathrm{~N}-1 \mathrm{E}-4 \mathrm{aa1}\end{array}$ & $\begin{array}{l}\text { Oct. } 29,1953 \ldots \\
\text { Oct. } 30,1953 \ldots \ldots \\
\text { May } 10,1954 \ldots \\
\text { May } 6,1954 \ldots \ldots \\
\end{array}$ & $\begin{array}{l}81 \\
40 \\
45 \\
34 \\
41\end{array}$ & $\begin{array}{l}\mathbf{G} \\
\mathbf{E} \\
\mathbf{E} \\
\mathbf{G} \\
\mathbf{E}\end{array}$ & $\begin{array}{l}4.19 \\
1.17 \\
1.35 \\
1.82 \\
1.22\end{array}$ & $\begin{array}{l}\mathrm{C}_{1} \mathrm{~S}_{1} \\
\mathrm{C}_{2} \mathrm{~S}_{1} \\
\mathrm{C}_{2} \mathrm{~S}_{1} \\
\mathrm{O}^{3} \mathrm{~S}_{1} \\
\mathrm{C}_{2} \mathrm{~S}_{1}\end{array}$ & $\begin{array}{l}1.79 \\
.24 \\
.45 \\
0 \\
0\end{array}$ & $\begin{array}{l}\mathrm{M} \\
\mathrm{S} \\
\mathrm{S} \\
\mathrm{S} \\
\mathrm{S}\end{array}$ \\
\hline $\begin{array}{l}86 \\
87 \\
88 \\
89\end{array}$ & $\begin{array}{r}\text { 1N-2E-6ab1 } \\
\text { 6dd1 } \\
1 \mathrm{~S}-2 \mathrm{Wdd2} \\
\text { 8dc1 }\end{array}$ & $\begin{array}{l}\text { Nov. 17, 1953 } \\
\text { Oct. 29, 1953 } \\
\text { May } 6,1954\end{array}$ & $\begin{array}{l}70 \\
61 \\
41 \\
86\end{array}$ & $\begin{array}{l}\mathbf{E} \\
\mathrm{G} \\
\mathrm{G} \\
\mathbf{D}\end{array}$ & $\begin{array}{l}\text { 3. } 19 \\
2.79 \\
2.41 \\
\text { 7. } 74\end{array}$ & $\begin{array}{l}\mathrm{C}_{2} \mathrm{~S}_{1} \\
\mathrm{C}_{2} \mathrm{~S}_{1} \\
\mathrm{C}_{3} \mathrm{~S}_{1} \\
\mathrm{C}_{2} \mathrm{~S}_{2}\end{array}$ & $\begin{array}{l}1.25 \\
.69 \\
0 \\
4.24\end{array}$ & $\begin{array}{l}\mathbf{M} \\
\mathbf{S} \\
\mathbf{S} \\
\mathrm{U}\end{array}$ \\
\hline
\end{tabular}

Surface water

\begin{tabular}{|c|c|c|c|c|c|c|c|c|}
\hline 80 & Snake River at Marsing & Sept. 25, 1953.... & 26 & G & 1. 17 & $\mathrm{O}_{2} \mathrm{~S}_{1}$ & 0 & $\mathrm{~S}$ \\
\hline 91 & $\begin{array}{l}\text { Boise River at Dowling } \\
\text { Ranch near Arrowrock. }\end{array}$ & Apr. $1-10,1939 \ldots$ & 24 & $\mathbf{E}$ & .35 & $\mathrm{C}_{1} \mathrm{~S}_{1}$ & .10 & $\mathbf{S}$ \\
\hline $\begin{array}{l}92 \\
93 \\
94 \\
95\end{array}$ & Moore Creek-Boise River. & $\begin{array}{l}\text { June 21-30, } 1939 \ldots \\
\text { Sept. 21-30, } 1939 . \\
\text { Dec. 21-31, 1939.- } \\
\text { Aug. 10, 1948.... }\end{array}$ & $\begin{array}{l}20 \\
28 \\
24 \\
14\end{array}$ & $\begin{array}{l}\mathbf{E} \\
\mathbf{E} \\
\mathbf{E} \\
\mathbf{E}\end{array}$ & $\begin{array}{l}.25 \\
.48 \\
.47 \\
.27\end{array}$ & $\begin{array}{l}\mathrm{C}_{1} \mathrm{~S}_{1} \\
\mathrm{C}_{1} \mathrm{~S}_{1} \\
\mathrm{C}_{1} \mathrm{~S}_{1} \\
\mathrm{C}_{1} \mathrm{~S}_{1}\end{array}$ & $\begin{array}{r}.05 \\
.18 \\
.15\end{array}$ & $\begin{array}{l}\mathbf{S} \\
\mathbf{S} \\
\mathbf{S} \\
\mathrm{S}\end{array}$ \\
\hline 96 & $\begin{array}{l}\text { Boise River at Diversion } \\
\text { Dam. }\end{array}$ & $\operatorname{Mar.~}_{1948}^{29-A p r .14}$ & 22 & $\mathbf{E}$ & .56 & $\mathrm{C}_{1} \mathrm{~S}_{1}$ & .08 & $\mathbf{S}$ \\
\hline $\begin{array}{l}97 \\
98 \\
99\end{array}$ & 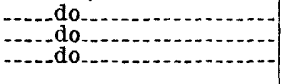 & $\begin{array}{l}\text { June } 7-21,1948 \\
\text { Sept. 6-20, 1948.-- } \\
\text { Dec. 1, 1948-Jan. } \\
24,1949\end{array}$ & $\begin{array}{l}23 \\
24 \\
21\end{array}$ & $\begin{array}{l}\mathbf{E} \\
\mathbf{E} \\
\mathbf{E}\end{array}$ & $\begin{array}{l}.65 \\
.67 \\
.65\end{array}$ & $\begin{array}{l}\mathbf{C}_{1} \mathrm{~S}_{1} \\
\mathrm{O}_{1} \mathrm{~S}_{1} \\
\mathrm{C}_{1} \mathrm{~S}_{1}\end{array}$ & $\begin{array}{l}0 \\
.26 \\
.05\end{array}$ & $\begin{array}{l}\mathrm{S} \\
\mathbf{S} \\
\mathrm{S}\end{array}$ \\
\hline 100 & - do do & $\begin{array}{l}\text { Mar. 21-Apr. 11, } \\
1949 .\end{array}$ & 18 & $\mathbf{E}$ & .49 & $\mathrm{C}_{1} \mathrm{~S}_{1}$ & 0 & $\mathbf{S}$ \\
\hline 101 & - do do - n & June $1-17,1949 \ldots$ & 16 & $\mathbf{E}$ & .42 & $\mathrm{C}_{1} \mathrm{~S}_{1}$ & & $\mathbf{S}$ \\
\hline 102 & $3 \mathrm{do}$ & Sept. 9-23, 1949..- & 18 & $\mathbf{E}$ & .47 & $\mathrm{C}_{1} \mathrm{~S}_{1}$ & .07 & $S$ \\
\hline 103 & Main south side Canal & Sept. 15, 1953 & 47 & $\mathbf{E}$ & .82 & $\mathrm{C}_{1} \mathrm{~S}_{1}$ & .25 & S \\
\hline $\begin{array}{l}104 \\
105\end{array}$ & Ridenbaugh Canal. ..... & Sept. 15,1953 & $\begin{array}{l}26 \\
48\end{array}$ & $\underset{G}{\mathbf{E}}$ & $\begin{array}{r}.50 \\
1.92\end{array}$ & $\begin{array}{l}\mathrm{C}_{1} \mathrm{~S}_{1} \\
\mathrm{C}_{2} \mathrm{~S}_{1}\end{array}$ & $\begin{array}{r}.13 \\
.26\end{array}$ & $\begin{array}{l}\mathbf{S} \\
\mathbf{S}\end{array}$ \\
\hline 106 & $\ldots$ do & Sept, 25, 1953 & 41 & $\mathrm{G}$ & 1. 55 & $\mathrm{C}_{2} \mathrm{~S}_{1}$ & 0 & $\mathbf{S}$ \\
\hline 107 & Boise River at Caldwell. & June $8-25,1948$ & 30 & $\ddot{E}$ & $\begin{array}{l}1.00 \\
.98\end{array}$ & $\mathbf{C}_{1} \mathbf{S}_{1}$ & & S \\
\hline 108 & - do & Sept. $17-30,1948$ & 46 & $G$ & 2.25 & $\mathrm{C}_{3} \mathrm{~S}_{1}$ & .75 & $\mathbf{S}$ \\
\hline 109 & $\begin{array}{l}\text { Boise River return flow } \\
\text { (Notus Canal). }\end{array}$ & Oct. 7,1948 & 41 & $G$ & 2. 65 & $\mathrm{C}_{2} \mathrm{~S}_{1}$ & & S \\
\hline 110 & do do & June 8-22, 1949... & 38 & G & 2. 30 & $\mathrm{C}_{3} \mathrm{~S}_{1}$ & 0 & $\mathbf{S}$ \\
\hline $\begin{array}{l}111 \\
112 \\
113 \\
114 \\
115\end{array}$ & $\begin{array}{l}\text { Boise River at Notus. } \\
\text { do do }\end{array}$ & $\begin{array}{l}\text { Sept. 13-26, 1949.- } \\
\text { Mar. 11-20, 1939.- } \\
\text { June 21-30, 1939_- } \\
\text { Sept. 11-20, 1939.- } \\
\text { Dec. } 11-20,1939 .\end{array}$ & $\begin{array}{l}44 \\
48 \\
60 \\
57 \\
49\end{array}$ & $\begin{array}{l}\mathrm{G} \\
\mathrm{G} \\
\stackrel{\mathrm{P}}{\mathbf{P}} \\
\mathrm{G}\end{array}$ & $\begin{array}{l}2.79 \\
2.38 \\
\text { 4. } 73 \\
\text { 3. } 55 \\
2.81\end{array}$ & $\begin{array}{l}\mathrm{C}_{3} \mathrm{~S}_{1} \\
\mathrm{C}_{2} \mathrm{~S}_{1} \\
\mathrm{C}_{3} \mathrm{~S}_{1} \\
\mathrm{C}_{3} \mathrm{~S}_{1} \\
\mathrm{C}_{3} \mathrm{~S}_{1}\end{array}$ & $\begin{array}{l}0 \\
0 \\
0 \\
0 \\
.31 \\
.10\end{array}$ & $\begin{array}{l}\mathbf{S} \\
\mathbf{S} \\
\mathbf{S} \\
\mathbf{S} \\
\mathbf{S}\end{array}$ \\
\hline
\end{tabular}




\section{CLASSIFICATION ACCORDING TO SODIUM-ADSORPTION RATIO}

The classification according to percent-sodium is not wholly satisfactory because it does not directly measure the potentiality for base-exchange adsorption of sodium by the soil. The sodiumadsorption ratio (SAR), however, approaches a direct measure of that potentiality. Field tests by the U. S. Salinity Laboratory have shown relatively good agreement between the exchangeable sodium percentage in samples of soil and the calculated SAR values. The SAR value, therefore, is a useful index of the sodium hazard of irrigation waters.

The SAR is derived by the equation,

$$
S A R=\frac{N_{a}^{+}+K^{+}}{\sqrt{\frac{1}{2}\left(C a^{++}+M g^{++}\right)}}
$$

in which, $\mathrm{Na}^{+} \mathrm{K}^{+}, \mathrm{Ca}^{++}$, and $\mathrm{Mg}^{++}$represent respective concentrations, in milliequivalents (me) per liter, of sodium, potassium, calcium, and magnesium. For classification, the ratios so derived are plotted against conductivity on another standard diagram which defines four ranges of salinity hazard and sodium hazard. SAR ratios from the available analyses of Boise Valley waters are given in table 23 and are plotted on figure 22 .

CLASSIFICATION BY RESIDUAL SODIUM-CARBONATE CONTENT

According to Eaton (after U. S. Salinity Laboratory Staff, 1954, p. 81)

Waters with more than 2.5 me/liter "residual sodium carbonate" are not suitable for irrigation. Waters containing 1.25 to $2.5 \mathrm{me} / \mathrm{liter}$ are marginal, and those containing less than 1.25 me/liter "residual sodium carbonate" are probably safe.

Within these limits, Boise Valley waters are classified in table 23. Four of the 89 samples of ground water are in the unsuitable class, 18 are in the marginal class, and 66 are in the "probably safe" class. One sample (no. 32) could not be classified because the content of sodium was not determined. All samples of surface water are in the "probably safe" class.

This classification supplements, and does not wholly supersede, the SAR classification because excessive bicarbonate in the water may aggravate the alkali hazard which the SAR method seeks to evaluate. 


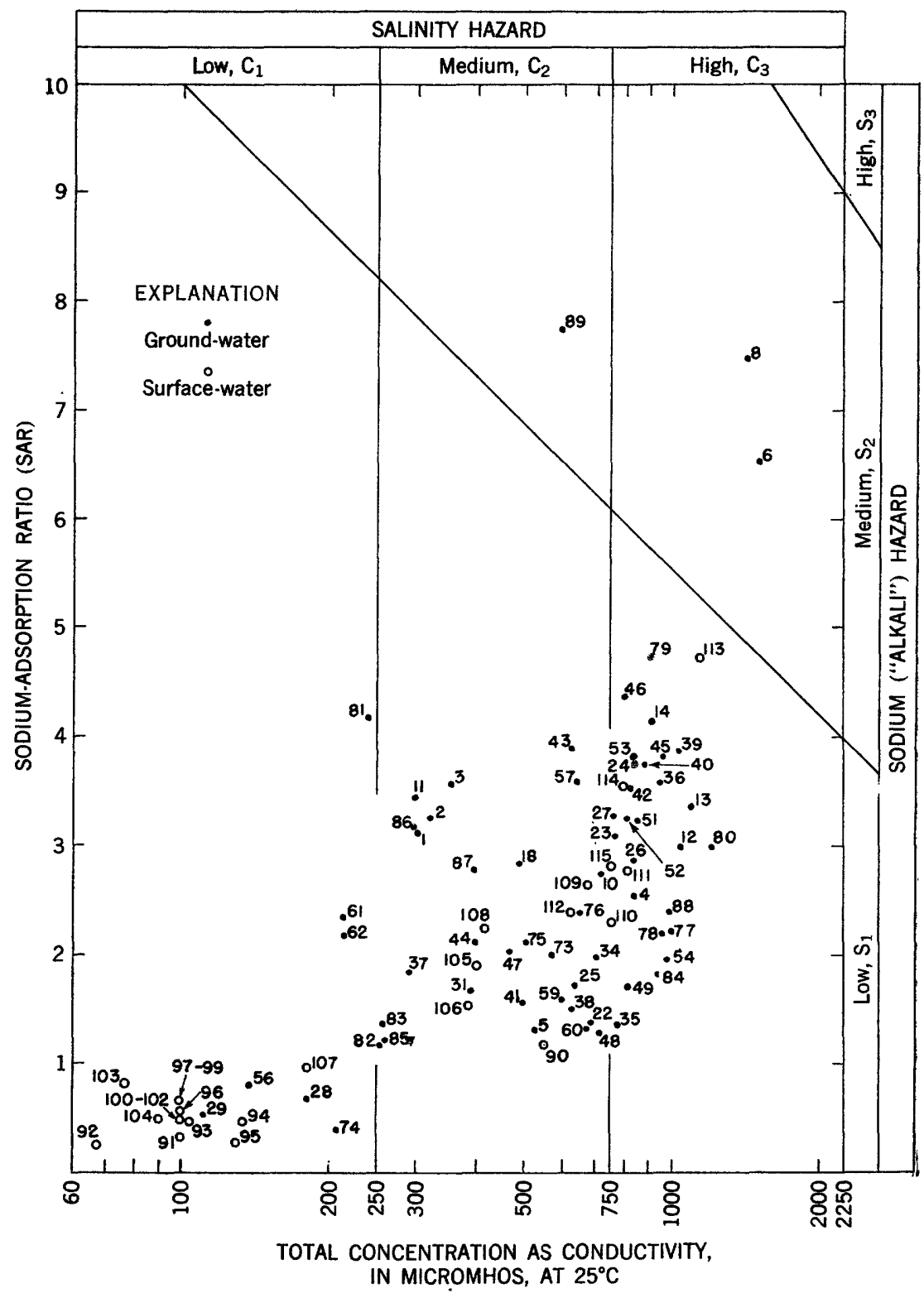

Fiqure 22.-Classification of Boise Valley waters according to sodium-adsorption ratios and concentration (method of U. S. Salinity Laboratory Stafi)). Numbers refer to locations in tables 23 and 24. 
COMPARISON OF THE THREE CLASSIHICATIONS

Table 24 summarizes the number of analyses falling into each of the several suitability classes, which grade one into another. The classification assumes average conditions of soil texture, infiltration capacity, drainage, quantity of irrigation water applied, climate, and salinity tolerance of the crop. Given a large deviation from average in one or more of these factors, a water, low both in dissolved solids and in proportion of sodium, might cause damage to the soil or, conversely, a water that, by these two criteria, is of doubtful quality might be used successfully (especially with appropriate use of soil amenders).

TABLE 24.-Distribution of analyzed samples among irrigation-suitability classes

Sodium-adsorption-ratio classification: Salinity hazard- $\mathrm{C}_{1}$, low; $\mathrm{C}_{2}$, medium; $\mathrm{C}_{3}$, high. Sodium or "alkali" hazard- $-S_{1}$, low; $S_{2}$, medium.

Eaton's classification symbols: S, safe; M, marginal; U, unsuitable.

\begin{tabular}{|c|c|c|c|c|c|c|}
\hline \multirow{3}{*}{$\begin{array}{l}\text { Sodium-adsorption-ratio classification } \\
\text { (According to U. S. Salinity Laboratory) }\end{array}$} & \multicolumn{6}{|c|}{$\begin{array}{l}\text { Number of analyses, distributed in } \\
\text { Eaton's classes, for- }\end{array}$} \\
\hline & \multicolumn{3}{|c|}{ Ground water } & \multicolumn{3}{|c|}{ Surface water } \\
\hline & $\mathbf{S}$ & $\mathbf{M}$ & $\mathrm{U}$ & $\mathrm{S}$ & $\mathbf{M}$ & $\mathrm{U}$ \\
\hline \multirow{2}{*}{$\begin{array}{l}\mathbf{C}_{1} \mathbf{S}_{1} \\
\mathbf{C}_{2} \mathbf{S}_{1} \\
\mathbf{C}_{2} \mathbf{S}_{2} \\
\mathbf{C}_{3} \mathbf{S}_{1} \\
\mathbf{C}_{3} \mathbf{S}_{2}\end{array}$} & $\begin{array}{r}17 \\
32 \\
0 \\
17 \\
0\end{array}$ & $\begin{array}{l}2 \\
8 \\
0 \\
8 \\
0\end{array}$ & $\begin{array}{l}0 \\
0 \\
1 \\
1 \\
2\end{array}$ & $\begin{array}{r}15 \\
5 \\
0 \\
5 \\
0\end{array}$ & $\begin{array}{l}0 \\
0 \\
0 \\
0 \\
0\end{array}$ & $\begin{array}{l}0 \\
0 \\
0 \\
0 \\
0\end{array}$ \\
\hline & \multicolumn{3}{|c|}{88} & \multicolumn{3}{|c|}{25} \\
\hline
\end{tabular}

Waters of class $\mathrm{C}_{1} \mathrm{~S}_{1}$ can, according to the U. S. Salinity Laboratory Staff (1954, p. 79-81), be used to irrigate most crops on most soils with little prospect that they will cause excessive soil salinity, and with little danger that sodium adsorption by the soil will be harmful except to sodium-sensitive crops such as the stone fruits. Special land- and irrigation-management practices might be necessary on soils having extremely low permeability.

Waters of class $\mathrm{C}_{2} \mathrm{~S}_{1}$ are only slightly less suitable for irrigation. Salt-sensitive crops might require special management practices.

Waters of class $\mathrm{C}_{2} \mathrm{~S}_{2}$ are not inferior if used on coarse-textured or organic soils having good permeability and drainage, such as the best soils in the Boise Valley. However, such waters entail an appreciable hazard that tillability will deteriorate if the soil is fine textured and contains no gypsum. Some areas in the Boise Valley may be susceptible to this hazard.

Waters of class $\mathrm{C}_{3} \mathrm{~S}_{1}$ cannot be used successfully on soils having poor drainage; even where drainage is adequate, salt-tolerant crops should be chosen and special management may be required. Soil drainage in parts of the Boise Valley is inadequate by this standard. 
Waters of class $\mathrm{C}_{3} \mathrm{~S}_{2}$ entail the additional hazard that the soil will deteriorate in tillability if it is fine textured and contains no gypsum.

There is substantial doubt that waters of classes $\mathrm{C}_{2} \mathrm{~S}_{2}, \mathrm{C}_{3} \mathrm{~S}_{1}$, and $\mathrm{C}_{3} \mathrm{~S}_{2}$ are suitable for irrigation on all soils and for all potential crops. Among the analyzed surface waters, these classes have been found only' in the Boise River at Notus and in the Notus Canal during the irrigation season. Among the ground waters they have been drawn from one spring and from wells that are scattered widely over all the Boise Valley west of Kuna and Meridian-the water-exchange area contemplated under the alternate plan. The samples were from wells that range in depth from about 50 feet to more than 400 feet.

Neither the available data nor the scope of this appraisal is adequate to bring out details in the pattern of distribution in the Boise Valley of the ground waters having doubtful suitability for irrigation. Full knowledge of that pattern will be essential in ultimate irrigation development of the valley, but the knowledge can be obtained only through intensive investigation for which no provision is made in the alternate plan. The probable origin of the pattern of distribution of the ground waters is explored on pages 82 to 84 of this report.

\section{UNCOMMON AND MINOR FACTORS IN IRRIGATION SUTTABILITY}

Boron, in very small amounts, is essential to proper plant growth, but larger amounts in irrigation water are injurious to many plants. Specifically, more than about $3.7 \mathrm{ppm}$ of boron is toxic even to plants that have a relatively high boron tolerance (U. S. Salinity Laboratory Staff, 1954). In Boise Valley waters that have been analyzed, the maximum boron content is $0.36 \mathrm{ppm}--$ an allowable amount even for boron-sensitive crops.

Fluoride, a minor constituent in most waters, in ordinary concentrations seemingly does not appreciably affect the irrigation quality of water. It is believed that the silica content usually does not influence the suitability of water for irrigation, although many soil scientists believe it has a part in stabilizing soil aggregates, forming impermeable hardpan, and contributing to plant nutrition. Iron in excess of 0.3 ppm is undesirable for irrigation use, chiefly because it forms incrustations that clog pipes and sprinklers. In most Boise Valley waters the iron content is much less than $0.3 \mathrm{ppm}$. Sulfate, chloride, and nitrate, which are present in nearly all natural waters, seem to have little significance in the suitability for irrigation of the waters in the Boise Valley and the Mountain Home area. 


\section{ORIGIN OF THE WATER-QUALITY PATTERN}

\section{NATURAL FACTORS}

In oversimplified terms, the chemical composition of a natural water represents a balance between the solubility and chemical activity of the soils and rocks over or through which the water moves, and the length of time the water has been in contact with those soils and rocks. In most of the Boise River watershed above Boise Diversion Dam, the rock materials contain relatively little soluble minerals; thus, stream water at the head of the irrigated area in the Boise Valley is low in dissolved solids (see table 25). The hardness and the amount of dissolved solids in the river water doubtless increased downstream in the environment before the advent of irrigation, owing in part to admixture of ground water. However, the chemical composition of river water at the lower end of the valley has been modified greatly by irrigation.

Alluvial gravel on the terraces of the Boise Valley is derived largely from the granitic terrane above Boise Diversion Dam. Ground water from the gravel therefore tends to be chemically similar to upstream Boise River water, though it is somewhat more mineralized because it has been longer and more intimately in contact with soluble minerals. The lowland gravel deposits are similar in mineral content to those on the terraces, but residual soils derived from them tend to contain larger amounts of soluble minerals. Ground water from the lowland gravel generally is more mineralized than that from terrace gravel.

Water from the Idaho formation characteristically is relatively high in fluoride $(0.8,1.4$, and $7.0 \mathrm{ppm}$ in wells $5 \mathrm{~N}-4 \mathrm{~W}-35 \mathrm{da} 1,4 \mathrm{~N}-$ $4 \mathrm{~W}-15 \mathrm{db} 1$, and $1 \mathrm{~S}-2 \mathrm{~W}-8 \mathrm{dc1}$; table 25$)$ and has a high ratio of sodium to total cations $(66,68$, and 80 percent, respectively), owing to the relative abundance of fluorine- and sodium-bearing minerals in the lake beds. Water in the deeper part of the Idaho formation is sufficiently well confined by materials of low permeability that it tends to be of distinctive quality, having a high percentage of sodium.

Practically all samples that were analyzed for fluoride contained an appreciable amount of that constituent, but concentrations harmful to bealth are not common. The highest concentration in beds other than those of the Idaho formation (3.5 ppm in well $3 \mathrm{~N}-2 \mathrm{E}-14 \mathrm{aa} 1)$ is in water derived from fluoride-bearing volcanic rocks similar to those which furnished much of the sediment that composes the Idaho formation.

\section{EFFECTS OF IRRIGATION}

The chemical quality of water inevitably depreciates as it moves through an irrigated area. In the Boise Valley such depreciation is believed to have been a principal factor in determining the current 
range in irrigation suitability of both surface and ground waters (fig. 22, p. 76-77). Ground water is the principal vehicle involved in the mechanism of depreciation.

Main irrigation canals in the Boise Valley convey stream water from the valley head across earth materials that are highly permeable in many canal reaches. The water contains substantially less dissolved minerals than the ground water that occurred naturally beneath the irrigated areas. Water lost by seepage from the canals locally dilutes the underlying mineralized ground water within irregular tongues having unknown width and reach westward from the valley head. Dilution, however, is not universal. A notable exception is water tapped by well $2 \mathrm{~N}-1 \mathrm{~W}-7 \mathrm{bc4}$, only 140 feet from an unlined canal. A water sample from this well contained $715 \mathrm{ppm}$ of dissolved solids (see table 25), nearly the highest concentration in any sample from south of the Boise River. Water in the canal on the same day contained only $51 \mathrm{ppm}$ of dissolved solids. There the canal evidently is insulated from the producing aquifer by an impervious layer.

Away from the inferred tongues of diluted ground water the effects of irrigation are altogether different, owing to the following principal factors:

1. Disintegrated crop-plant debris provides soluble nitrogenous matter and weak acids which are taken up by infiltrating water, and the solvent power of the infiltrate may exceed substantially that of natural recharge water.

2. Soil amenders and fertilizers afford soluble materials that do not occur naturally. These may be dissolved in substantial amount by infiltrating irrigation water.

3. Growing plants transpire a substantial amount of water but incorporate in their tissues only a minute portion of the mineral matter dissolved in that water. Substantially all the mineral matter originally in the transpired water remains in the soil or is carried downward, ultimately into the underlying ground water, by the water not transpired. In the Boise Valley, on the average, the ratio of irrigation water to transpired water is such that the residual which percolates to ground water would, if no modifications intervened, have a dissolved-solids concentration about 150 percent of that of the irrigation water. Further, residual water is recovered repeatedly as return flow and is reused for irrigation. Thus, mineral matter in recharge water from irrigation in the extreme western part of the valley may be several times more concentrated than in the valleyhead river water.

4. Fine-textured earth materials, which are abundant in the Boise Valley, contain sodium-base exchange minerals. In these materials, 
water would exchange its calcium and magnesium for an equivalent amount of sodium, either in part or substantially in whole.

5. If carbonate and bicarbonate in the irrigation water are considerably more than equivalent to the calcium and magnesium, the carbonates of these two cations may precipitate in the soil. Thereby, the proportionate amount of sodium in the ground-water recharge is increased, the sodium alkalinity increases, and the tendency toward solution of organic matter and formation of "black alkali" is increased.

The principal net effect of the chemical actions is to increase, in the ground water, both the absolute amount of dissolved solids and the relative amounts of sodium, sulfate, and chloride, thus depreciating the suitability of the water for irrigation. The effect is cumulative and considerable as water moves through the valley, because drainage water is intercepted for reuse in several successive irrigation cycles, each cycle further depreciating the quality. Chemical modifications such as those described are inferred to be largely responsible for the quality of ground waters of classes $\mathrm{C}_{2} \mathrm{~S}_{2}, \mathrm{C}_{3} \mathrm{~S}_{1}$, and $\mathrm{C}_{3} \mathrm{~S}_{2}$, previously described.

Ground-water discharged from the greater part of the Boise Valley reaches the Boise River, either as underflow or by way of surface drains. (See pl. 5.) This return flow is irrigation water that has been modified in chemical composition in the manner just described. At the climax of the irrigation season such water constitutes a substantial to major part of the river flow at Notus; thus, the chemical character of the river water depreciates progressively from Boise Diversion Dam downstream. Return flow is continuous, but during the nonirrigation season its effect on the quality of river water is less noticeable, because it is diluted by surface runoff that passes the diversion dam.

The effects of irrigation on the chemical quality of Boise River water were the subject of a special study by the Geological Survey in 1939-40 (Love and Benedict, 1948). Samples were collected from the river above and below the principal irrigated area, from canals, and from Lake Lowell. Daily samples were taken from the Boise River at Notus from January 13, 1939 to January 17, 1940. Snake River water also was sampled. This study yielded the selected representative analytical results in table 25 and figure 19.

Between Boise Diversion Dam and Notus the average increase in dissolved solids was several hundred parts per million. Between the two stations the chemical differences in the water varied during the year, the difference being at a minimum in late winter and early spring. when natural flow was high relative to return flow. 
In contrast, water from the Snake River at Marsing contained several times as much dissolved solids as Boise River water near Arrowrock Dam, but less than Boise River water at Notus (table 25 and Jensen, Lewis, and Baker, 1951). The suitability of the Snake River water for irrigation is only moderately inferior to that of the Boise River water at Notus and is definitely superior to Boise River return water at Notus. 


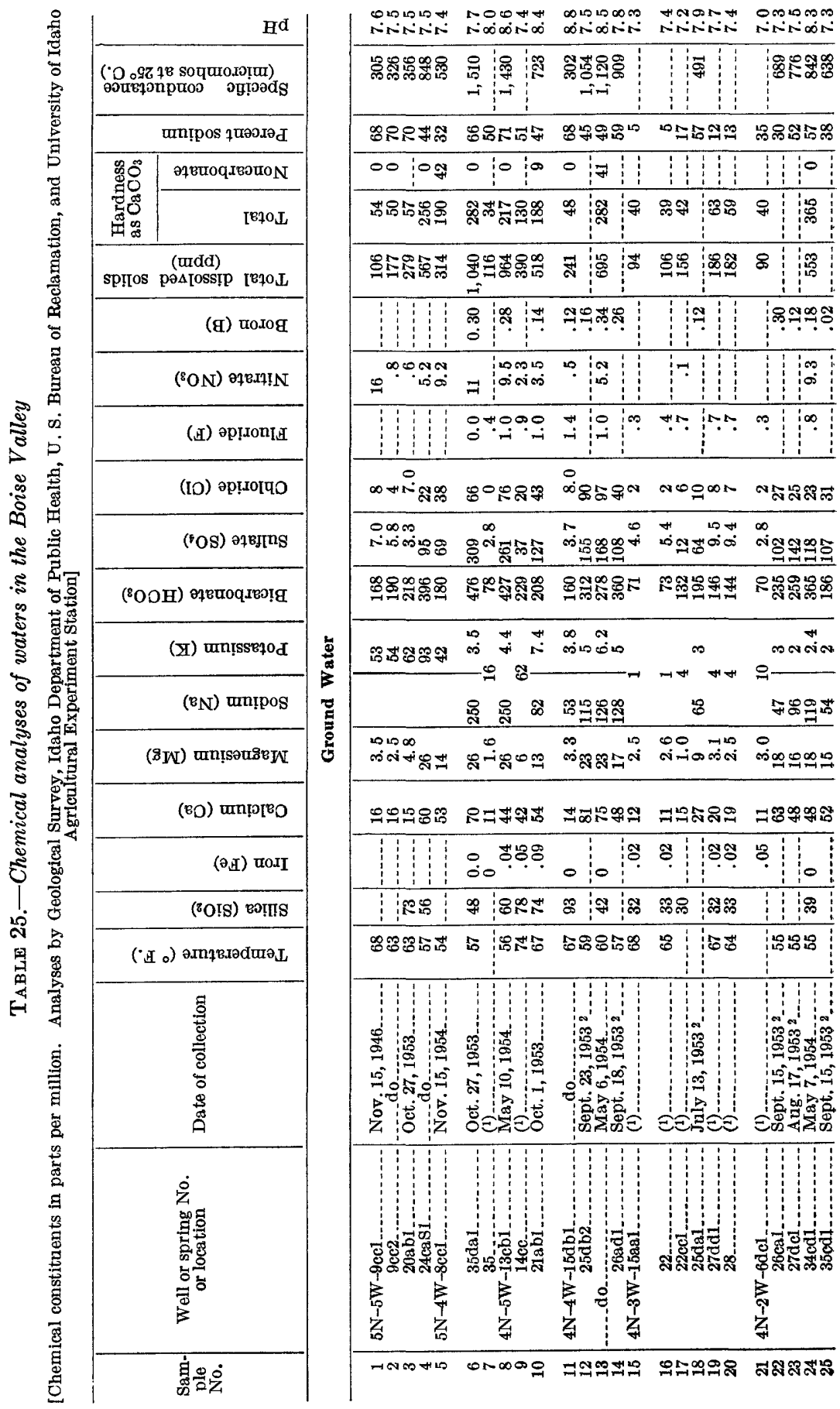




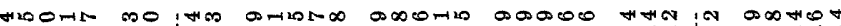
NRSH

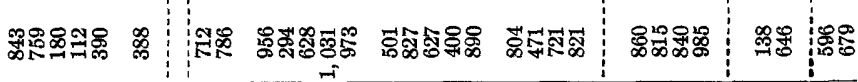

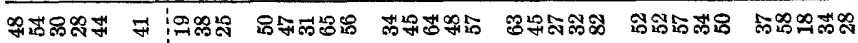

\begin{tabular}{|c|c|c|c|c|c|c|c|}
\hline 100 & \begin{tabular}{l|l|l}
$\circ$ & 0 H
\end{tabular} & 00 & & 100 & & ○०स & $\infty$ \\
\hline ठூस & 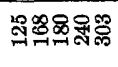 & గణ: & & $\log _{7}=$ & :F & 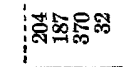 & 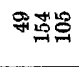 \\
\hline \begin{tabular}{l:l}
$\infty$ \\
\hdashline
\end{tabular} & : & 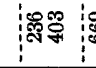 & & : & 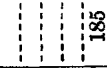 & 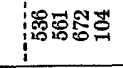 & 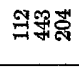 \\
\hline$\because: 7$ & 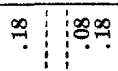 & 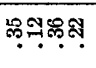 & & $\begin{array}{l:l}\% & 0\end{array}$ & 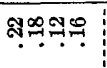 & 풍ㅇㅇㅇ & \% \\
\hline & 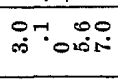 & : & $\underset{\infty}{\infty}$ & $=0$ & 0 & $\min _{\infty} \infty 0_{0}$ & $\underbrace{\infty}_{i=\infty}$ \\
\hline & อ. & - & & $\infty$ & in & •" & ฯ \\
\hline
\end{tabular}

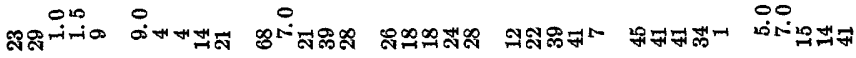

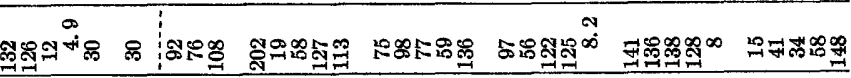

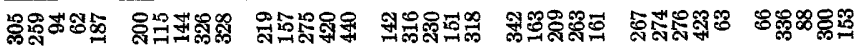

\begin{tabular}{|c|c|c|c|c|c|c|c|}
\hline ma $\stackrel{\circ}{-m}$ & $\vec{\infty}$ & $\begin{array}{l}\infty \\
500 \\
500\end{array}$ & 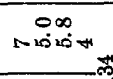 & $\operatorname{arns}$ & 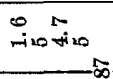 & $\begin{array}{l}\infty \times 1 \\
\text { avion } \\
\end{array}$ & $\infty_{-\infty}^{\infty}=$ \\
\hline $5 \infty \stackrel{20}{\sim \infty}$ & $F$ & : & స్తాలి & 소ㅇㅛㅡ & 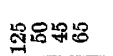 & : & 옥 정뉴 \\
\hline 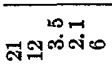 & $\Rightarrow$ & ம் & 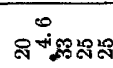 & 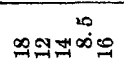 & 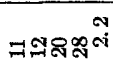 & 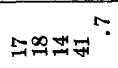 & "ాఖ్ల \\
\hline
\end{tabular}

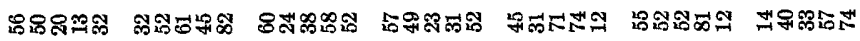

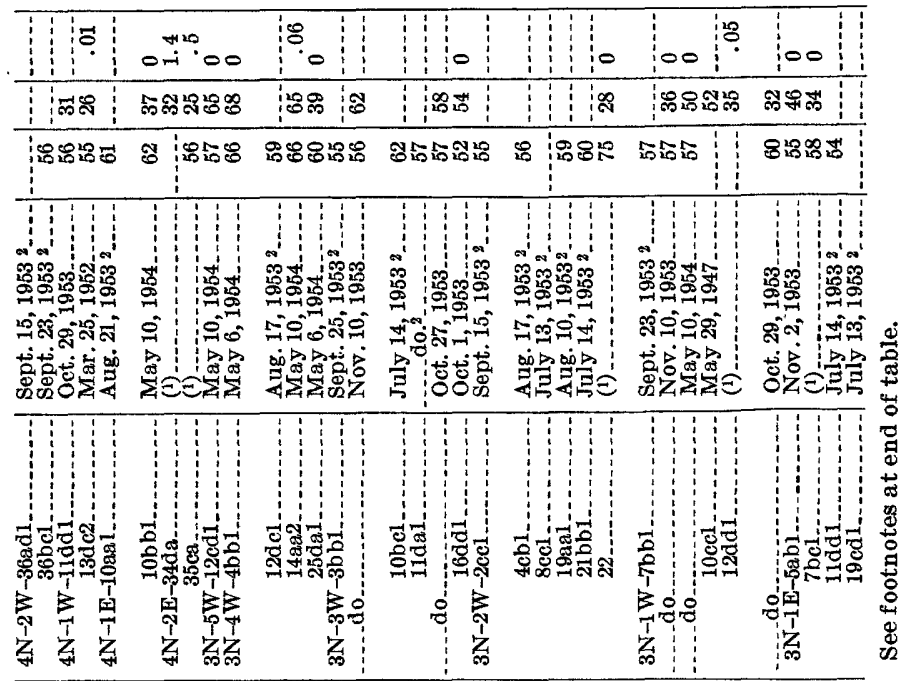

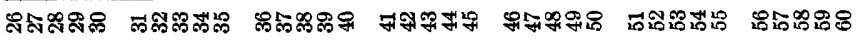




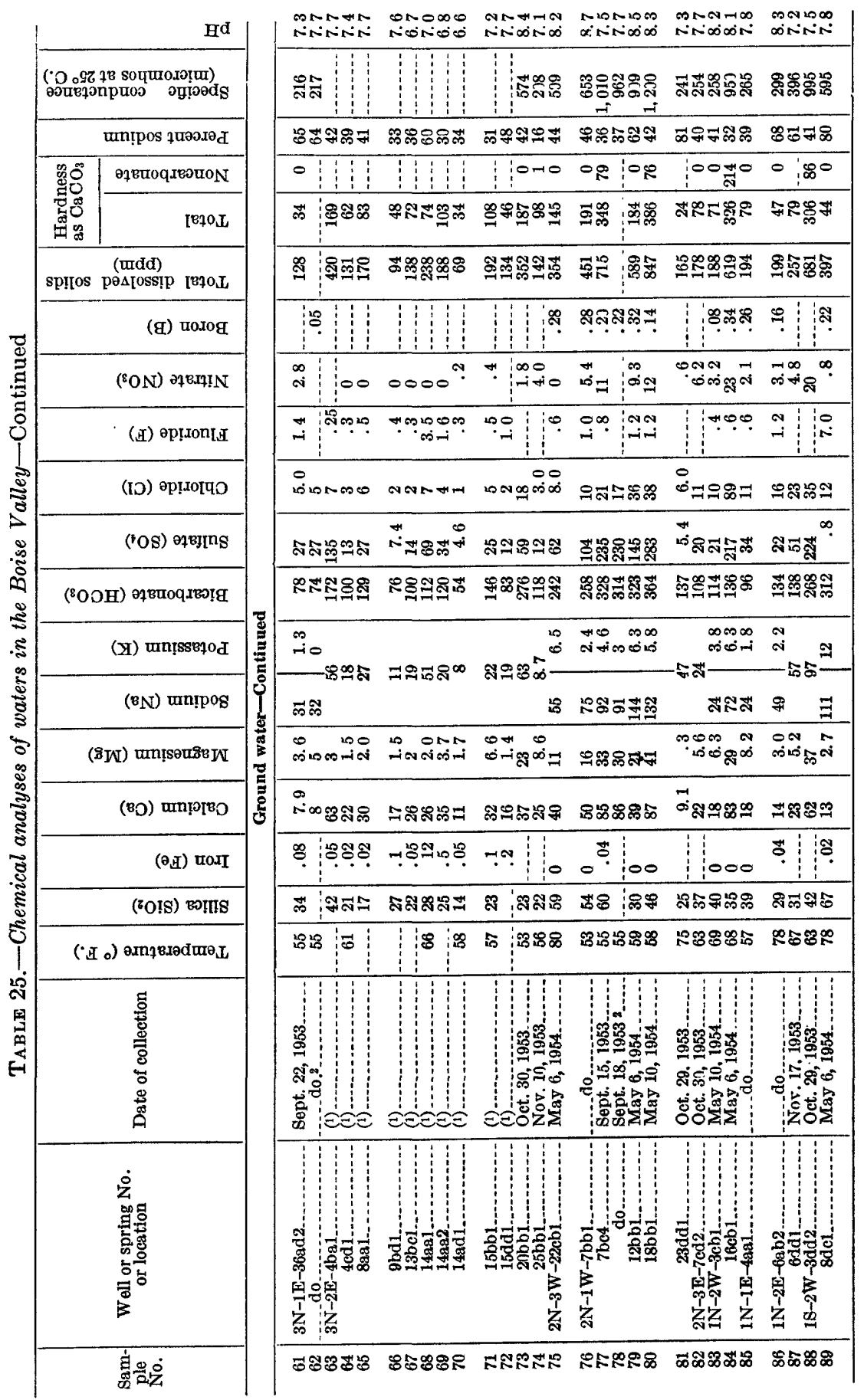




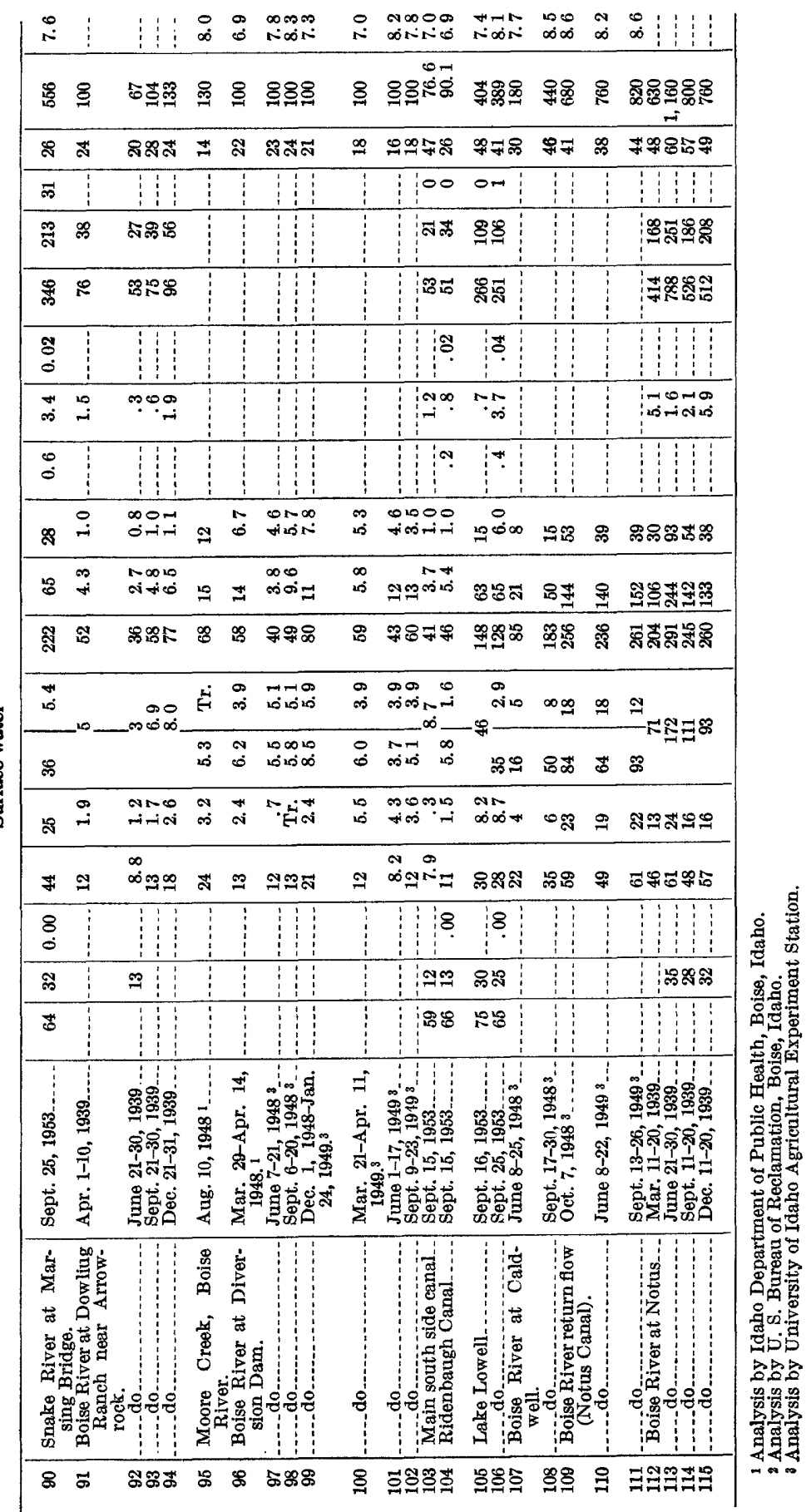




\section{SALT BALANCE}

Under the conditions prevailing in the Boise Valley, the suitability of the water for irrigation can be maintained only if water is allowed to waste in a quantity sufficient to carry out excess dissolved salts. The so-called salt balance is favorable only so long as the chemical quality of the water finally applied to the land does not exceed tolerable limits of salinity hazard and sodium hazard. Available data suggest that the Boise Valley may be on the verge of an unfavorable salt balance, and an unfavorable balance might develop during a succession of dry years such as occurred in the thirties. An investigation much more intensive than was feasible for the present appraisal would be required to determine the actual existing salt balance.

Operation of the alternate plan would tend to change the present salt balance of the Boise Valley, and make it less favorable, because the ground water that would be pumped for exchange and offsetlikewise, the surface water that would be pumped from the Snake River into Lake Lowell--would be less suitable in quality for irrigation than the water it would replace. The balance would become still less favorable if the plan should result in a substantially smaller minimum river flow, or a more prolonged period of low flow, passing Boise Diversion Dam during the irrigation season. Whether the less favorable balance could be tolerated is not answerable from facts now in hand.

\section{FEASIBILITY OF THE ALTERNATE PLAN}

The task of this report is to determine, in terms of hydrology and geology, whether the alternate plan is physically feasible and could be operated successfully for an indefinitely long time, and to evaluate the hydrologic aspects of the plan in terms of advantage or disadvantage, compared to the benefit or nonbenefit of not executing the plan, or of executing a different plan. The evaluation necessarily is broad in scope, having in mind the ultimate needs of the entire area in which the plan would operate (Carr, 1953).

\section{BASIC PROPOSALS AND ASSUMPTIONS OF THE ALTERNATE PLAN}

The alternate plan makes the following basic proposals (Sloan, 1953):

1. Divert yearly 60,000 acre-feet of surface water from the Boise River at Lucky Peak Dam to the Hillcrest division of the Mountain Home project, and 540,000 acre-feet from the South Fork of the Boise River to the Long Tom division.

2. Pump 150,000 acre-feet of Snake River water into Lake Lowell to replace an equal amount of exported Boise River water. 
3. Pump 150,000 additional acre-feet of Snake River water as part of a power-generation scheme. Generate power as an incident to operations (1) and (2).

4. Pump yearly an average of 225,000 acre-feet of Boise Valley ground water to replace an equal amount of exported Boise River water; in years of short surface-water supply in the Boise River, pump as much as 75,000 acre-feet of supplemental ground water; that is, a total of as much as 300,000 acre-feet.

5. Pump additional ground water to replace depleted return water now used to satisfy downstream rights.

6. Drain 225,000 acres of waterlogged land in the Boise Valley as an essential incident to pumping ground water for irrigation.

These proposals of the alternate plan are based on certain major assumptions, on the validity of which depend the physical feasibility and ultimate advantage of the entire plan. These assumptions, expressed or implied, are as follows:

1. Diversion requirement for Mountain Home plateau.

a. That the gross water-diversion requirement for Mountain Home land would be 4.85 acre-feet per acre, compared to 5.4 feet estimated in the original plan (expressed).

b. That 540,000 acre-feet of live water is present in the South Fork of the Boise River at the proposed diversion point and at the proposed time of diversion, and that this water could be inade available to the Long Tom division. Further, that 60,000 acre-feet of water in the Boise River at Lucky Peak Dam could be made available to the Hillcrest division (expressed).

c. That 225,000 acre-feet of Boise River water above Boise Diversion Dam is surplus and could be exported without the need for replacement water (expressed).

2. Exchangeability of Snake River water. That 150,000 acre-feet of Snake River water could be pumped into Lake Lowell and exchanged for the same volume of Boise River water (implied). That power generation is feasible as an incident to this exchange (expressed).

3. Exchangeability of Boise Valley ground water.

a. That ground water at the well head can be exchanged, acre-foot for acre-foot, for Boise River water above Boise Diversion Dam (implied). The plan recognizes, however, that the surface water is not necessarily completely replaceable by the exchange, and provides for a small amount of additional pumping to offset reduced return flow.

b. That the ground water is chemically suitable for irrigation, would remain so for all time, and is a suitable substitute for part of the present surface-water supply (implied).

4. Availability and accessibility of ground water. 
a. That 225,000 to 300,000 acre-feet of usable ground water is available and accessible within an area where it could be practicably substituted for surface water (expressed).

b. That 450 irrigation and drainage wells, spaced one-fourth mile apart and "adjacent to each of the main supply canals below the Boise Diversion Dam," would deliver the required amount of replacement water during a pumping season of 125 days (expressed).

c. That additional satisfactory wells can be installed wherever needed to satisfy local shortages of water that may develop owing to depleted return-flow (expressed).

d. That the wells would have an average depth of 60 feet, and an average pumping lift of 65 [sic] feet, with an average yield of $2.0 \mathrm{cfs}$ (expressed).

5. Drainage benefits.

That pumping 225,000 to 300,000 acre-feet of water from wells would lower the water table 4.5 to 5 feet beneath 225,000 acres of land (expressed).

Minor additional assumptions also are involved.

Obviously these proposals of the alternate plan have far-reaching implications. The plan would alter the patterns of water supply and use in three major geographic areas: the Boise River basin, the Snake River valley, and the Mountain Home plateau. Accordingly, determining the validity of the major assumptions is appropriate as a test of the feasibility of specific proposals. An analysis of the assumptions follows, each being considered in the order listed above, except for the assumption about chemical suitability of the water. The chemical quality has been discussed in detail (pp. 70-90) and further discussion of chemical quality is deferred to the end of this section in order not to interrupt discussion of the mechanics of exchanging and replacing water.

\section{DIVERSION REQUIREMENT FOR MOUNTAIN HOME PROJECT}

The alternate plan fixes the gross water-diversion requirement for new project land at 4.85 acre-feet per acre, computed as follows:

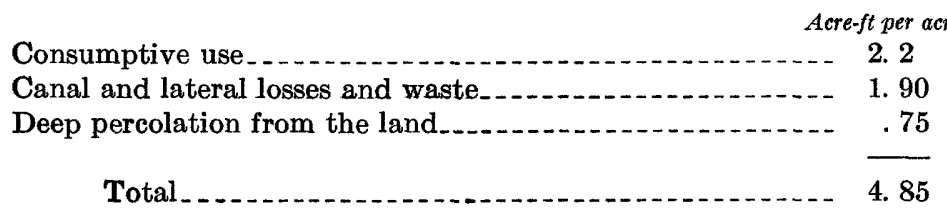

The proposed delivery of water to farms under the alternate plan is not stated as such but apparently would be 2.95 acre-feet per acre: 2.2 acre-feet for consumptive use and 0.75 acre-foot for deep percolation, or 74 percent of the 4.0 acre-feet per acre now delivered to 
Boise Valley farms. The writers know of no irrigated area in Idaho that operates voluntarily with a farm delivery of water as small as 2.95 acre-feet per acre. The original plan proposed a water-diversión requirement of 5.4 acre-feet per acre, plus rediversion of some return water.

The appropriate duty of water for Mountain Home lands depends partly on operational procedures, irrigation practices, and other factors with which the present report is not concerned. Hydrologic and geologic factors that would materially influence the duty of water, however, are appropriate topics for discussion here.

The alternate plan states (Sloan, 1953) that "This figure of 4.85 acre-feet per acre is identical with average diversions of Boise River natural stream flow over the last 10 years." Apparently it was assumed that all diversions from the river above Notus are "natural stream flow." Actually, however, in recent years these diversions have included an average of 200,000 acre-feet of water that already has been used once and is merely being recycled, according to records of the Bureau of Reclamation in 1954. Additional water is diverted from drains before it reaches the Boise River and the volume of gross diversions is about 5.6 to 6.0 acre-feet per acre. Delivery of water to farms in the Boise Valley ranges from about 3.7 to 4.5 feet to individual farms, despite the advantage that summer rainfall supplies about 0.2 foot of the consumptive-use demand. Presumably very little consumptive use on the Mountain Home project would be satisfied by rainfall during the growing season.

An appropriate estimate of diversion requirements for the Mountain Home land probably could be made with farm-delivery requirement as a starting point. Transmission losses and recovery of return flow then could be estimated and added to obtain the value for diversion requirements.

In much of the Mountain Home plateau the soil is Iargely windblown material overlying basalt; there are extensive sandy and gravelly areas. A somewhat similar area is the Minidoka North Side pumping division of the Minidoka project. New land on that project currently is being developed with ground water, and the estimated duty of water at well heads on or near farms is about 3:65 acre-feet per acre. This is understood to include about 0.15 foot for transmission loss and farm waste, leaving about 3.5 feet for farm delivery. So far as climate and geologic materials are concerned, the wa ter requirement for the Mountain Home plateau probably would not be less than that for the Minidoka North Side division. Improved irrigation efficiency and extensive use of sprinkler irrigation might reduce the requirement as much as 10 percent, or to 3.1 feet. 
The alternate plan allows 40 percent ( 1.9 acre-ft per acre) for "canal and lateral losses and waste." The actual losses would depend on the permeability of geologic materials at the surface and at shallow depth beneath canals and irrigated fields. On the Mountain Home plateau the older terrace gravel, alluvium of Indian Creek, and windblown silt occur in substantial areas that would be irrigated and through which canals would pass. These materials are similar in composition and permeability to the younger terrace gravel, alluvium of Indian Creek, and fine-grained sediments in the Boise Valley, through which there are extensive canal systems.

Thus it must be assumed that transmission losses and deep percolation on the plateau would be as great as, or greater than, in the Boise Valley, where canal and lateral losses are 30 percent and farm waste is about 5 percent. The allowance of 40 percent under the alternate plan total thus may be adequate. Recovery of water, at least in early years of operation, would not be as extensive on the plateau as it is in the valley, owing to differences in the subsoil and geologic materials at shallow depth and to the depth to the water table. In parts of the plateau the soil is underlain by tight basalt, caliche, and fine sediments on which percolating water might perch and ultimately be discharged to drainageways where it would be available for rediversion. Perched or semiperched ground water occurs in the vicinity of Mountain Home, where recharge is partly from irrigation and would be increased by new irrigation. The project water supply ultimately might be increased by pumping perched ground water.

On the other hand, much of the plateau is underlain by permeable basalt and sediments through which water would percolate downward to the water table, some hundreds of feet below. Ground-water recharge from irrigation will raise the water table to some new equilibrium level which cannot be predicted. That level, however, may be sufficiently high that ground-water will be discharged to surface drainageways within parts of the project. Failing that, the depth to water may be sufficiently small in some areas to permit economical pumping from the regional zone of saturation.

The amount of water that could be recycled is indeterminate and in any event extensive recycling would not be possible in early years of operation. Thus, only a small quantity of water for recycling could be presumed in estimates of the initial diversion requirement. Assuming a requirement of 3.1 to 3.5 feet for delivery. to farms, and transmission loss of 1.9 feet, the diversion requirement would be 5.0 
to 5.4 feet, or near the requirement estimated in the original plan. ${ }^{7}$ If the original-plan estimate is correct, and the diversion requirement actually is 5.4 acre-feet per acre, then the area served under the alternate plan would have to be reduced by 12,500 acres; that is, by slightly more than the area of the Hillcrest unit, or by 10 percent of the total alternate-plan land.

\section{AVAILABILITY OF BOISE RIVER WATER}

The alternate plan assumes that 540,000 acre-feet of water will be available in the South Fork of the Boise River for diversion to the Long Tom division. Records of the discharge of the South Fork immediately below Anderson Ranch Reservoir cover only the period since April 1943, during which runoff was somewhat more than normal. The average yearly discharge during that period was slightly more than 600,000 acre-feet. The lowest discharge of record was 458,000 acre-feet in 1944; in several years the discharge was less than 540,000 acre-feet. The currently allotted irrigation-storage space in Anderson Ranch Reservoir is 418,000 acre-feet. Evidently more of the available space would have to be used for holdover storage, and this would decrease the amount of water available for power generation during the nonirrigation season, as well as the total output of firm power. A firm supply of 540,000 acre-feet thus is not available for the Long Tom division from perennial river discharge. Availability of the water therefore depends on availability of holdover storage, on reservoir operations, and on flow-routing procedures.

There appears to be little question of the availability of 60,000 acre-feet of water for the Hillcrest Division, but, in conjunction with diversions from the South Fork, the entire river and reservoir operation would be involved.

The availability of 225,000 acre-feet of surplus Boise River water above Boise Diversion Dam is confirmed in the base-period average. However, the exact place and the time of availability remain to be substantiated. The surplus is only part of the total diversion requirement of the alternate plan; its amount determines how much surface water would not have to be replaced with ground-water. Thus, the fact is decisive that, in 6 of the 20 base-period years, there was little or no surplus surface water and there were actual deficits ranging from 3,800 to 107,000 acre-feet. A dry year or series of dry years would

7 After this report was prepared the United States Bureau of Reclamation released, in duplicated form, a report on the alternate plan (Bur. Reclamation, Region I, Special Report. The alternate plan for Mountain Home Irrigation and Drainage project, Idaho, 83 p.; dated November 1954 but actually released in April 1955). According to that report the estimated diversion requirement is 5.2 feet for the Long Tom unit and 5.5 feet for the Hillcrest unit, to.permit farm delivery of 3.8 acre-feet per irrigable area. 
require availability of water from holdover storage in Anderson Ranch Reservoir. Thus the whole water requirement of the plan depends on operation of the reservoir and on downstream diversion requirements.

\section{EXCHANGEABIIITY OF SNAKE RIVER WATER}

The alternate plan proposes to pump 150,000 acre-feet of Snake River water into Lake Lowell to replace an equal amount of Boise River water. As much as 150,000 additional acre-feet of water would be pumped into the lake for temporary storage, later to be discharged by gravity back to the Snake River through a power-generation penstock. The latter provision, incidentally, would provide reserve capacity to pump additional replacement water from the Snake River in years of short supply from the Boise. It has been suggested that the reserve capacity might be increased as a safety factor. Such an increase probably is not feasible, for operational reasons.

Lake Lowell currently is filled yearly with live water from the Boise River, diverted through the New York Canal and Deer Flat feeder canal. Substitution of live water from the Snake River would not alter the water-supply status of land served by the reservoir, which depends on the live water and return flow therefrom. The estimated loss from the existing canals (see p. 47) contributes to usable return flow east of Lake Lowell, but this could not be replaced at Lake Lowell. Exchange of Snake River water for an equal volume of Boise River water would be reasonable only if the exchange were for water delivered at the reservoir. Presumably, actual delivery of live Boise River water at Lake Lowell is about 142,500 acre-feet $(150,000$ acre-feet less a transmission loss of perhaps 5 percent).

The proposed extra pumping capacity on the Snake River could provide a real reserve capacity to furnish replacement water. It seems, however, that replacement in excess of 300,000 acre-feet a year would not be feasible because 300,000 acre-feet of live water, plus diverted return flow derived therefrom, is a full supply for all land served by Lake Lowell (Bureau of Reclamation records; 1954) - that is, no more than 300,000 acre-feet of Snake River water would be usable in the Boise Valley on land served by Lake Lowell.

Feasibility of the power-generation provisions of the alternate plan, including pumping from the Snake River, manipulation of Lake Lowell, and return of water from the lake to the river, depends partly on geologic and hydrologic factors. The permeable basin of Lake Lowell allows large losses of water by infiltration. Siltation gradually has sealed the floor of the lake and reduced the rate of loss since the reservoir was first filled, but loss still is substantial at high-water stages, when reservoir content exceeds 100,000 acre-feet (figs. 23, 24). The negative losses shown by the graphs are gains in reservoir content from return of bank storage. Use of the high-level storage 


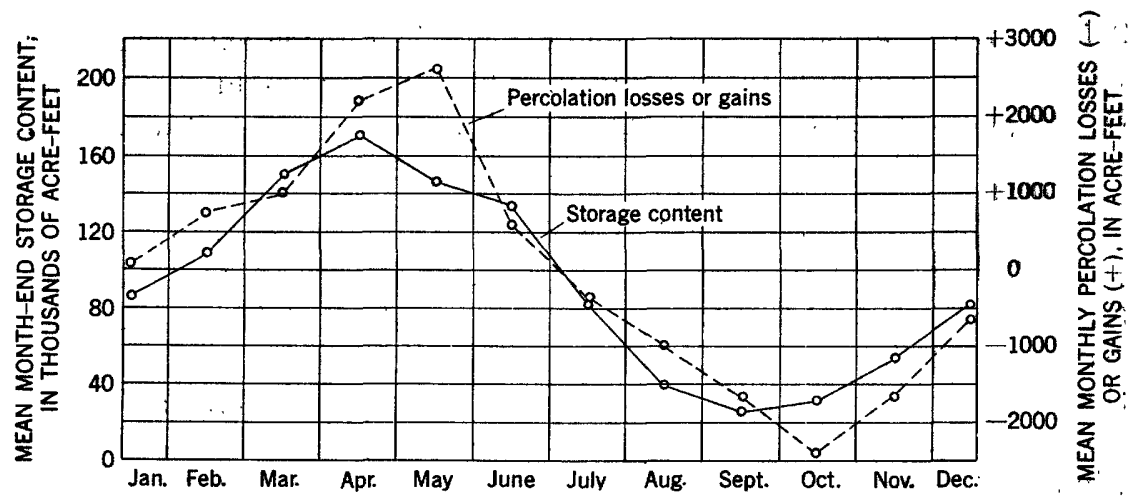

FIGURE 23.-Mean monthly percolation losses or gains and mean monthend storage content of Lake Lowell reservoir for the period 1931-50.

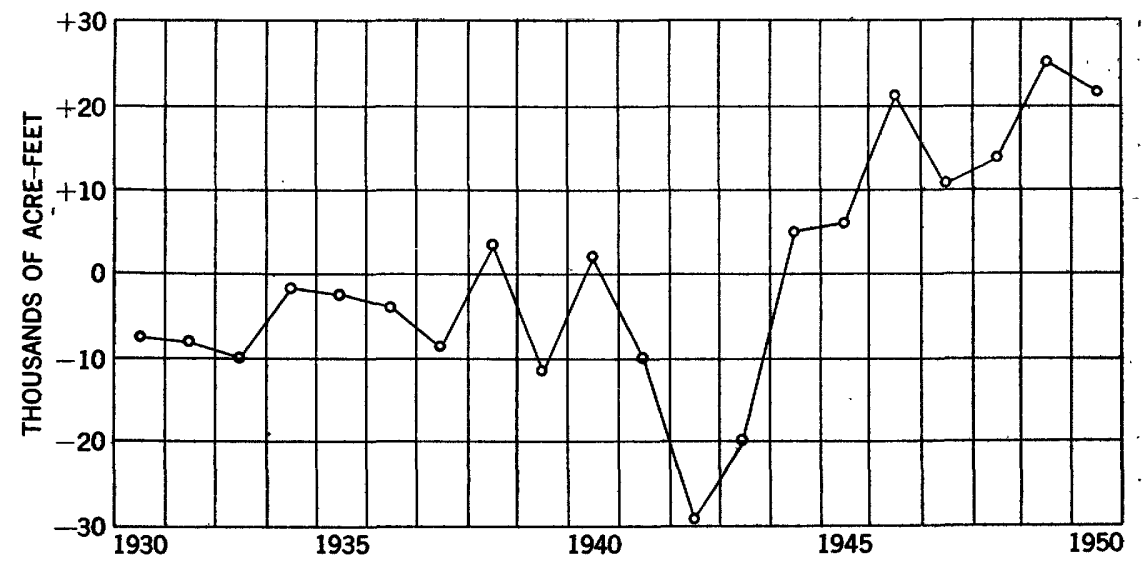

FIGURE 24.-Yearly percolation losses from Lake Lowell reservoir for the years 1931-50.

space during the irrigation season would increase the total yearly loss, shift the time of the principal return seepage into the nonirrigation season, and probably cut down total return by shortening the return period. Owing to these infiltration losses at high storage levels, all the water pumped from the river would not be returnable, acre-foot for acre-foot, to generate power. Moreover, if power generation required a full reservoir when the storage level otherwise would be low, the ground-water regimen and drainage situation in areas adjacent to the reservoir would be affected.

\section{EXCHANGEABIUITY OF BOISE VALIEY GROUND WATER}

Ground water pumped under the alternate plan would include two replacement categories, exchange water and offset water. The two collectively are here called replacement water. Exchange water- 
225,000 acre-feet per year-is that which will replace exported river water on an exchange ratio of unity. Offset water would be pumped to compensate the effects of diminished surface water in the valley.

\section{EXCHANGE WATER}

The alternate-plan proposal to exchange 225,000 acre-feet of ground water for an equal amount of surface water implies that water from the two sources is equivalent, acre-foot for acre-foot. That assumption is correct only in a narrow sense. Ignoring the depletion of return flow that will be caused by pumping ground water, in general a foot of water at any point in the irrigated area has the same potential value, whatever its source, and at the given point the given water will be disposed partly by consumptive use, partly by ground-water recharge, and partly by return flow and rediversion. Thus, under the alternate plan there would be no essential qualitative change in the regimen of diversion (considering pumping as a type of diversion), rediversion, or application of water to the land. Quantitative changes, however, would be substantial: the total amount of surface water in the valley and the return flow from that water would be diminished, and return flow would be further diminished, because ground-water levels would be lowered by pumping.

Presumably, for the alternate plan to be acceptable to Boise Valley water users, an undiminished supply of irrigation water must be assured. Such assurance would be possible only if the total effect of the alternate plan on the water supply were foreseen and if provisions were made, as necessary, to offset adverse effects. The return-flow and rediversion regimen in the irrigated area is very complex. Inadequacies of available data prevent accurate quantitative analysis of all the factors in this regimen. It is clear, however, that a simple exchange of ground water for exported Boise River water, acre-foot for acre-foot, would not assure continued delivery of an undiminished water supply at farm headgates.

\section{OFFSET WATER}

Pumping of offset water is not provided for quantitatively in the alternate plan, either in the estimates of construction, operation, and maintenance costs or in the estimate of the required volume of ground-water pumpage. Under the alternate plan the amount of water passing Boise Diversion Dam would be diminished by 600,000 acre-feet per year. Removal of much of this water would have little or no effect on the return-flow regimen in the Boise Valley. Specifically, the 225,000 acre-feet of surplus river water never gets onto irrigated land and does not enter the return-flow regimen. The 150,000 acre-feet that normally goes to Lake Lowell contributes a few percent of its volume to ground-water recharge (transmission loss 
between diversion point and Lake Lowell). Part of this recharge migrates to the Mountain Home plateau, and only the remainder contributes to Boise Valley return flow. If this remainder is half the total canal loss its amount is in the order of 20,000 acre-feet a year (see p. 47); potential diminution of valley return flow in this amount would be relatively inconsequential. Thus, the dominant critical factors are removal from the Boise Valley irrigation system of 225,000 acre-feet of surface water, and pumping 225,000 acre-feet or more of ground water.

Water originating above Boise Diversion Dam has an effective volume, on the irrigated lands, greater than its actual volume at the dam, owing to salvage and reuse of return flow. The ratio of live water to the effective usable volume on the land ranges between 3.8 to 5.8 and 4.1 to 6.0 (see pp. 36-37). The greater the distance from the point of diversion the greater the usable net increase in the water, owing to the greater number of times the water is recycled. For the exchange area (east of Notus) the ratio of increase is somewhat less than for the project as a whole, because replaced water is recycled. fewer times. The ratio 1 to 1.6 has been suggested as an appropriate average for the exchange area by the Bureau of Reclamation. According to that estimate it would require 1.6 acre-feet of pumped water in the exchange area to replace 1 acre-foot of live water originating above the diversion dam, and 360,000 acre-feet of ground water would be required to replace 225,000 acre-feet of live water. If additional ground water were pumped in years of short surface supply to compensate a shortage of 75,000 acre-feet of live water, as suggested in the alternate plan, the maximum ground-water pumpage would be 480,000 acre-feet.

The opinion outlined above holds, in effect, that the volume of water pumped at any place on the project must equal the effective volume of water diverted at Boise Diversion Dam. However, the ratio 1 to 1.6 merely expresses the amount of return flow (1.6 feet) that must be recovered and placed in the system in order to meet the farm-delivery requirement of 4.0 feet. An alternative view is that no offset water need be pumped for that land because return flow need not be recovered for the land served by ground water.

Neither of the above viewpoints considers adequately the basic fact that, in order to assure a continued full supply of water in the Boise Valley, ground water would have to be pumped in whatever quantity is necessary to offset the effects on the entire system of removing 225,000 acre-feet of live surface water and of pumping replacement ground water. The first view, requiring an exchange ratio of 1 to 1.6, makes no allowance for the effects of pumping. The second view ignores the fact that removal of the surface water would 
affect return flow in all the exchange area and beyond that area, not. just in specified parts of it.

\section{TOTAL REPLACEMENT WATER}

The proposal of the alternate plan to export 225,000 acre-feet of water would remove from the Boise Valley system 16 percent of the $1,400,000$ acre-feet of live river water estimated to be required for a full supply to Boise Valley lands. Return flow would be depleted at least 16 percent. Actual depletion would be appreciably more than 16 percent because lowered ground water levels would diminish the ratio of return flow to the live water remaining in the system. Depletion that would result from this cause is assumed here to be 20 percent of the return flow, or 80,000 acre-feet $(1,800,000$ acre-feet gross diversion minus $1,400,000$ acre-feet live water supply equals 400,000 acre-feet return flow used, times 0.20 equals 80,000 acre-feet). The implied total replacement water required would be 225,000 plus 80,000 or 305,000 acre-feet. Because of the method used for computation, this would be true whether the pumped wells delivered water directly to farms or delivered it to main canals and laterals. This simple calculation, however, ignores the further depletion of return flow that would ensue when ground-water pumping withdrew from storage the water that maintains currently high ground-water levels and return flow. In some areas of intensive pumping, return flow might cease altogether. Indeed, it is basic to the effectiveness of the alternate plan that lowering of water levels must occur; otherwise there would be no drainage benefit.

The depletion of return flow that will be caused by withdrawal of ground water from storage cannot be estimated at this time. Inevitably, however, pumping would lower ground-water levels progressively to some undetermined equilibrium level. At some places the lowering would be less than a foot. Elsewhere it would be a few feet to some tens of feet. In much of the area usable return flow might cease altogether. In that case questions of volumes of offset water and exchange water would be academic-it would be necessary to pump whatever water is needed to supplement that available from the Boise River.

Heavy ground-water draft or substantially lowered ground-water levels probably would intercept some of the present surface-water supply by inducing greater loss from flowing canals and drains, at least locally (see p. 67). Such interception would require pumping of additional offset water, the amount of which cannot be estimated from data at hand. From the above considerations it is evident that the ground-water pumping required in a normal year under the al ternate plan probably would be substantially more than 300,000 acre-feet a year, 
rather than 225,000. If depletion of return flow becomes widespread the required volume of pumpage might rise to 400,000 acre-feet or more. If extra ground water were pumped in years of short surface water supply, total pumpage might approach 500,000 acre-feet a year. In other words, the ratio of replacement to exported water probably would not be less than 1.3 to 1 and in dry years might exceed 2 to 1 .

\section{AVAILABIIITY OF BOISE VALLEY GROUND WATER}

The alternate plan states that 225,000 to 300,000 acre-feet of ground water is available and accessible within an area where its recovery and exchange for surface water would be practicable. The area of practicable recovery and exchange is called herein the exchange area (fig. 11). Within the lowland some substantial outlying areas contribute to the exchange area by ground-water underflow. The northern highland also contributes by underflow to the lowland.

The estimates on pages 42,43 , and 47 of this report indicate that potential yearly recharge in the contributing area is about 86,000 acre-feet by underflow from the northern highland, 35,000 acre-feet from the eastern upland; and about 320,000 acre-feet from irrigation. Thus the potential total from all sources is 554,000 acre-feet. Identified ground-water depletion currently is about 232,000 acre-feet, but much of the depletion occurs west of the contributing area. The residual, uncommitted potential recharge thus is more than 322,000 acre-feet and possibly approaches 400,000 acre-feet. The amount of the potential that actually becomes recharge is not known but may approach the amount of replacement water that ordinarily would be pumped under the alternate plan-300,000 to 400,000 acre-feet.

Exportation of 225,000 acre-feet of surface water would lessen potential ground-water recharge somewhat, as has been shown, but certain compensating factors would operate. Without the alternate plan, future diversion of surface water to the Boise Valley probably will approach a full supply of $1,400,000$ acre-feet, because operation of Anderson Ranch Reservoir has increased the supply of divertible live water. Under this regimen the volume of potential ground-water recharge from irrigation would be 809,000 acre-feet per year (see p. 47) less 20,000 acre-feet lost by underflow to the Mountain Home plateau, or 789,000 acre-feet. (Note that that amount would be potential recharge; some of the water would run off at the surface without recharging ground water.) Exportation of 225,000 acre-feet of surface water would diminish potential recharge from irrigation to about 584,000 acre-feet a year in the entire irrigated area, or about 105,000 acre-feet less than the 689,000 acre-feet of potential annual recharge during the base period. Distributed proportionately, the decrease in the exchange area would be roughly 57,000 acre-feet. 
Lowered water levels, caused by pumping ground water, would diminish natural ground-water discharge and increase the amount of recharge that could be accepted; that is, so long as recharge is being rejected, pumping may cause recharge to increase, thus automatically providing for partial replenishment of the pumped water. Eradication of water-loving native vegetation, whose consumptive use is large, also would increase the amount of uncommitted ground water.

Evidently, owing to the interplay of various factors in the water regimen of the Boise Valley, the amount of actual ground-water recharge under the alternate plan would not be much less than it is at present. Potential perennial recharge in the contributing area still would be in the range of 300,000 to 400,000 acre-feet a year, and actual recharge might be about equal to total replacement pumpage.

\section{ACCESSIBIHITY OF THE GROUND WATER}

Granting that the required amount of water is available for pumping in the Boise Valley, a crucial remaining question is what part of the total supply is accessible. That is, how much can be intercepted and used during the pumping season? The feasibility of the entire alternate plan hinges largely on the answer to this question, because, if the required amount of water cannot be obtained, the rest of the plan will be largely unworkable.

It is not possible to intercept and recover by pumping all the perennial ground-water recharge because natural ground-water discharge, a continuous year-round process, cannot be stopped altogether. Moreover, pumping would occur during less than half the year. Although the pumping and irrigation seasons would coincide, not all the recharge from irrigation could ${ }^{\bullet}$ be recovered. Discharge and uncommitteed potential recharge probably do not exceed the total probable pumping demand and it would not be feasible to recover 100 percent of the total supply. There are, however, two mitigating features: Some ground water may be pumped outside the exchange area if depletion of return flow requires offset water to be pumped west of Caldwell. About one-third of the pumped ground water would be consumed by crop plants and about two-thirds would become potential return recharge. Net ground-water depletion under the alternate plan would be on the order of 100,000 to 150,000 acrefeet a year. Return recharge would lag somewhat after pumping, so that depletion at the close of the irrigation season would be less than pumpage but more than ultimate depletion.

Seemingly, ground water to operate the alternate plan is available in the required average yearly volume of 300,000 to more than 400,000 acre-feet. Whether that quantity could be withdrawn yearly within the 6-month irrigation season and without local temporary mining of 
some water (lowering of water levels below a reasonable maximum pumping lift) remains uncertain. Furthermore, it is not certain that mined water would be replenished before the onset of another irrigation season and there is no assurance that withdrawal of ground water at the desired average rate would be practicable in all parts of the valley for all time. To answer these fundamental questions would require intensive investigation, possibly as suggested on pages 114-115. The prospects warrant such investigation.

\section{WELL DISTRIBUTION AND CHARACTERISTICS}

The alternate plan proposes to install 450 irrigation and drainage wells, spaced one-fourth mile apart and "adjacent to each of the main supply canals below the Boise Diversion Dam." The plan assumes that the wells would have an average capacity of $2 \mathrm{cfs}$, that the gross pumping capacity would be $900 \mathrm{cfs}$, and that 225,000 acre-feet of water would be pumped during a season of 125 days.

\section{CAPACTTY AND NUMBER OF WHLLS}

Wells distributed equally in the four ground-water districts of the Boise Valley probably would have an average capacity of $2.6 \mathrm{cfs}$ or more, with a 30-foot drawdown (table 21, p. 59). The number of wells presumably would be proportionately large in the Nampa and Meridian districts, where the average capacity of existing wells is $2.7 \mathrm{cfs}$ with 30 feet of drawdown. The gross capacity of 450 such wells would be $1,215 \mathrm{cfs}$, or 301,000 acre-feet in a 125-day pumping season. Extending the season to 180 days would increase the seasonal capacity to 433,000 acre-feet. With greater drawdown still greater yields could be obtained. Thus, the number of wells specified in the alternate plan probably would suffice to deliver all replacement water necessary in ordinary years. If extra water were to be pumped in dry years either the number of wells might need be increased or the cost of higher pumping rates with greater drawdown would need be accepted.

\section{DISTRIBUTION OF WEMLS}

The alternate plan proposal to locate wells at quarter-mile intervals along all main supply canals below Boise Diversion Dam assumes that well sites can be selected entirely on the basis of convenience for delivering the pumped water. This proposal is not feasible because at many places lowering of the water table by such wells would increase percolation losses from canals having permeable floors, the wells would not effectively drain some areas remote from the canals, where drainage is most needed, and interference between wells would be unnecessarily great. 
EFFECT ON PERCOLATION LOSS FROM CANALS

Loss of water by percolation out of canals and laterals is substantial in parts of the Boise Valley, overall loss being 25 to 30 percent of diversions (including some canal- and ditch-end losses, which cannot ibe segregated). Long reaches of some canals are continuous with the water table. Pumping from wells along such canals inevitably would increase percolation loss at some places (see p. 67) because the lowered water table would increase the hydraulic gradient out of the canals. Water drawn out of canals and pumped back in would be merely recirculated, and hardly could be considered as replacement water.

Canals that are in impermeable earth material, or that are lined with sealing materials, would not be affected materially by pumping nearby wells. Also, canals that are above the water table, as seems to be true of much of the New York canal, would not be affected.

Relatively free circulation of water from a canal to the water table is illustrated in the vicinity of well $3 \mathrm{~N}-2 \mathrm{E}-25 \mathrm{bb2}$, which is about 400 feet from the Ridenbaugh Canal on the Broadway terrace. The water level in the well rose about 5 feet within 11 days after water was turned into the canal in the spring of 1954. This rise was caused by rapid ground-water recharge with water lost from the canal. Similar conditions are common in parts of the Boise Valley adjacent to most principal canals.

Obviously, it would not be feasible to install a large number of wells indiscriminately along any and all canals. Intensive field study would be necessary to delineate canal segments where excessive percolation loss would be induced by draft from wells.

Inasmuch as the available water supply occurs in both artesian and nonartesian aquifers, it might be feasible to tap artesian water in some areas where it would not be feasible to pump shallow water. Pumping certain deep artesian aquifers would have no effect on canals even if they were close at hand.

\section{INTERTERENCE AMONG WELLS}

Inasmuch as the radius of appreciable influence of an ordinary pumped well in the Boise Valley is about 2 miles, pumping from one well in a line of wells spaced at intervals of one-quarter mile would lower the water level in the nearest eight wells on either side. Simultaneous pumping of all wells would produce a drawdown in each equivalent to its own normal drawdown plus the cumulative drawdowns from the 16 wells within its area of influence.

Application of drawdown data for four Pioneer Irrigation District wells illustrates the foregoing statement. The average drawdown in the pumped wells was 23.8 feet. The computed average drawdown (table 18, p. 56) after 30 days of pumping was 3.9 feet at a distance 
of one-quarter mile away, and 3.0 feet half a mile way. Assuming that wells were spaced, in line at quarter-mile intervals, with the average drawdowns stated above, the approximate drawdown in a given well during pumping of five wells would be as follows:

Drantidow
(fiet)

From pumping the given well

From pumping two wells, one on either side, at a distance of one-quarter mile $(3.9 \times 2)$

From pumping two wells, one on either side, at a distance of one-half mile $(3.0 \times 2) \ldots$

Total $\ldots \ldots \ldots$

After pumping for 180 days the total drawdown would be 43.8 feet. By the same method the cumulative drawdown during pumping of all wells within the area of influence could be calculated. The drawdown at a lateral distance of 2 miles from the line would be less than a foot. These calculations disregard the simultaneous reeharge that would ensue if the pumped water or surface water were used for irrigation within the pumped area, and also any effect of induced recharge from canals. With such recharge the actual net drawdown would, of course, be less than that just calculated.

Given such interference between wells, pumping along the New York Canal would have appreciable advantages: (1) The groundwater divide, now near the canal, would shift southward and some ground water that now passes into the Mountain Home plateau would be drawn into the Boise Valley. (2) In much of its course the eanal seemingly is above the water table, and pumping along such segments would not increase percolation losses. Thus, from the sole standpoint of water production, pumping adjacent to the New York Canal may be desirable. Drainage benefits from these wells, however, might be small.

\section{DEPTH AND PUMPING LIFT}

The alternate plan states that the average depth of irrigation and drainage wells in the Boise Valley would be about 60 feet. The actual average well depth that would be necessary is not a critical factor in the physical feasibility of developing ground water, but it is a material factor in the cost of construction. The average depth of existing irrigation and drainage wells in the Boise Valley is about 124 foet. The average depth of the wells in the Pioneer Irrigation District, the most productive ground-water district in the valley, is 132 feet.

An average depth for wells that would be constructed under the alternate plan could not be estimated closely until the locations have been determined. Along much of the New. York Canal the depth to water is 50 to 100 feet and the average depth of wells there. would 
approach 150 feet. Elsewhere in the valley wells probably would be 75 to 150 feet deep, with an average of more than 100 feet. Wells to tap artesian water would be as much as 400 feet deep, and in places perhaps even more.

The average pumping lift also would depend on the locations of wells. Along the New York Canal the lift probably would range from about 80 to 130 feet. Elsewhere the pumping lift would range from a few feet to about 80 feet. In general it seems likely that the average depth of wells would be between 125 and 150 feet, and the average pumping lift probably would be between 60 and 80 feet.

\section{DRAINAGE BENGFTS}

The alternate plan asserts that pumping 225,000 to 300,000 acre-feet of water annually would lower the water table 4.5 to 5 feet beneath 225,000 acres of land. This assertion seems to be unfounded (see $p$. 54). Furthermore, gang pumping of wells along main supply canals, as proposed in the plan, would not accomplish satisfactory drainage because much of the land needing drainage would be remote from the area of influence of wells so placed.

In this instance the basic factors that would control drainage benefits are the ability of well pumping to prevent the water table rising to undesirable levels, and the net amount of ultimate lowering of the water table in waterlogged areas. For substantial drainage benefit, the alternate plan would need be modified by dispersing irrigation and drainage wells in groups throughout the exchange area, with individual wells at critical locations. Even with such modification the ultimate drainage effect would not be felt immediately. The water table would decline progressively for some years, but neither the time lapse until equilibrium would be reached nor the depth of the water table at ultimate equilibrium can be estimated accurately from information now available.

Despite these uncertainties, suitably located wells and groups of wells would lower the water table or decrease its rise by at least several feet in many areas, especially because replacement pumpage necessarily would exceed substantially the amount assumed in the alternate plan. Very likely the lowering would range between wide extremes, from a fraction of a foot to some tens of feet. Many wells probably would be satisfactory both for drainage and for production of irrigation water. Maximum efficiency for both purposes, however, would not necessarily be achieved. Where economical water production is a sole objective, highly permeable aquifers would be sought in areas where pumping lifts would be low and where the water could be used efficiently. Effective drainage wells, on the other hand, would need be located where they would lower the water table beneth a thers that 
require drainage. Hence some drainage wells necessarily would be placed where aquifers are less permeable, where heavy drawdown therefore would occur, and where water might be used only inefficiently if at all.

\section{COST OF WELLS AND PUMPS}

Cost analyses have not been made for this report because properly they are a part of the engineering evaluation of the alternate plan. Factors that would affect these costs, however, are appropriate for notation here.

The average depth of wells would be between 125 and 150 feet and the diameters of casing between 18 and 24 inches, depending on the type of construction necessary for a specified yield at a specified location. In much of the Boise Valley, well screens or special types of perforated casing would be necessary and considerable development of the wells would be required for satisfactory well performance. The alternate plan estimated the average well depth at only 60 feet, and simple open-end construction probably was assumed to estimate an average cost of $\$ 6,700$ per well. It is apparent, however, that the cost of individual wells would be substantially greater, owing to construction requirements different from those assumed. On the other hand, adequately constructed wells should average at least a third more in yield than the plan assumed. This greater yield would offset some part of the greater cost per well.

\section{CHEMICAL SUITABIITTY OF REPLACEMENT WATHR}

The water-exchange proposal of the alternate plan does not consider the chemical suitability of the ground water for irrigation, though such quality is a fundamental factor. The preceding analysis of irrigation suitability of Boise Valley waters (pp. 70-85) shows the following basic situation:

1. Some ground waters are of excellent quality for irrigation but others entail a substantial salinity hazard or sodium hazard, possibly an intolerable hazard, for certain soil types or crops.

2. The present areal distribution of unsuitable waters cannot be delimited from information now in hand, except that such waters have been found in wells scattered in the valley west of Kuna and Meridian. The distribution might be such as to limit seriously the area or areas within which replacement pumping would be advisable.

3. The valley may be on the verge of an unfavorable salt balance, at least locally or for years of low streamflow. As proposed, the alternate plan inevitably would cause the salt balance to become less favorable.

Under the circumstances, the writers believe that the irrigation suitability of Boise Valley waters would need to be explored inten- 
sively before its full impact on the alternate plan could be appraised. Current information shows a possibility that operation of the plan, as now proposed, in time might depreciate water quality sufficiently to impair the agricultural productivity of parts of the valley.

\section{PRINCIPAL CONCLUSIONS}

To operate satisfactorily for an indefinitely long time the alternate plan must assure perennial availability of an adequate water supply for the Mountain Home project; perennial availability of an undiminished supply of chemically suitable irrigation water for Boise Valley land; decisive and widespread drainage benefits to Boise Valley land.

The general conclusion of this report, from analysis of specific elements of the plan, is that substantial modification of the alternate plan would be required to adapt it to limitations imposed by the geologic and ground-water environment. Furthermore, because the plan is ambitious in scope, considerable study would be necessary prior to construction. The principal physical modifications would be in the proposals to pump only 225,000 to 300,000 acre-feet of ground water a year, and to pump this water from wells at quarter-mile intervals along existing main canals. Thorough study would be needed of the return-flow regimen in existing drainageways, of the effects of pumping on return flow and on drainage problems, of the sources and actual amounts of ground-water recharge, of the chemical quality of all sources of water, and of several other specialized problems.

Twelve principal elements and several subelements of the alternate plan are listed in table 26, a summary of the analysis and principal conclusions. Three of the principal elements involve engineering and economic factors outside the scope of study by the Geological Survey, but they involve geologic and hydrologic factors discussed in this report. Of the remaining 9 principal elements, 5 definitely are infeasible in the form proposed in the alternate plan; the feasibility of 2 elements is questionable; only 2 definitely are feasible.

Modification of the plan would render some of the infeasible and questionable elements feasible, but the feasibility of other critical elements is not resolved. Specifically, it cannot be assured at this time that the full amount of ground water actually required by a modified plan is available and accessible during the irrigation season. Moreover, some ground water in the Boise. Valley is chemieally: undesirable, and operation of the alternate plan:would aggravate problems of water quality. 
TABLE 26.-Feasibility of specific elements of the alternate plan

[Leaders in feasibility column means that determination of ultimate feasibility involves engineering or other factors not within the scope of this report]

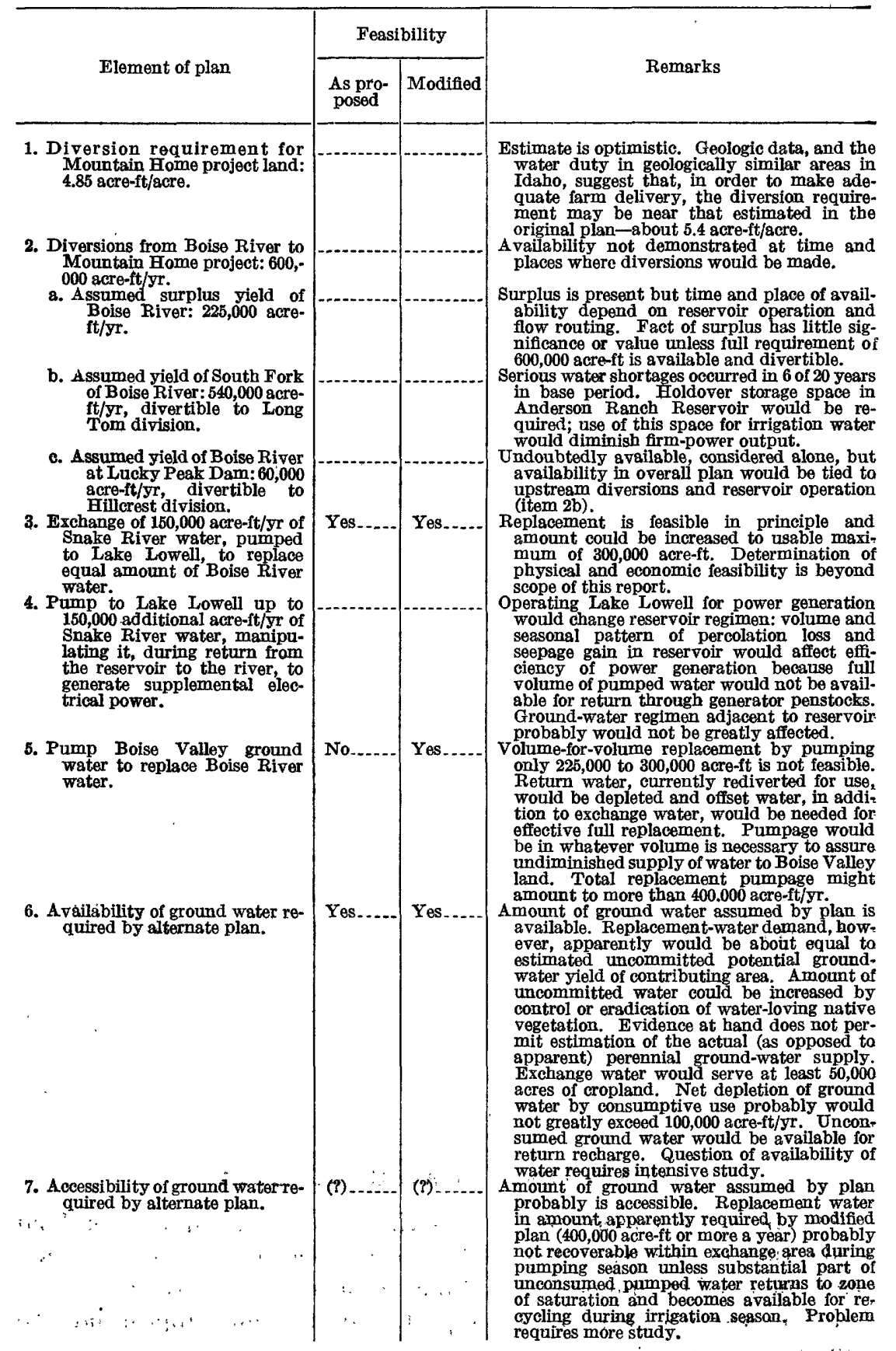


TABLE 26.-Feasibility of specific elements of the alternate plan-Continued

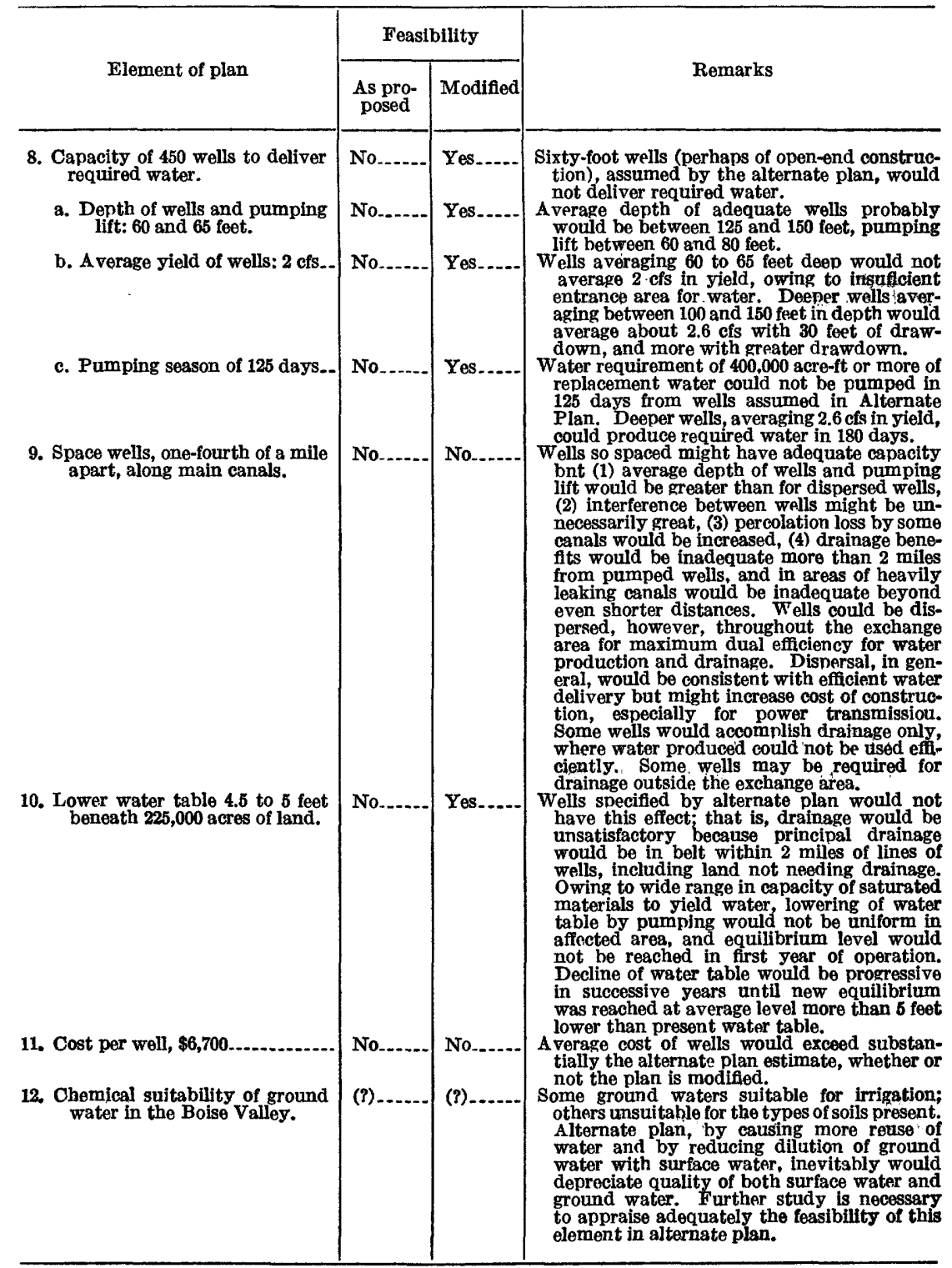

\section{COMPETENCE OF AVATLABLE DATA}

The basic data available at this time are not adequate for final evaluation of the feasibility of hydrologic features of the alternate plan, modified or unmodified. Principal deficiencies in the data were noted in various parts of this report, but it seems appropriate to summarize them at this point. 
1. The area actually irrigated in the Boise Valley, and its distribution, are not accurately known. Some tracts supposedly irrigated with surface water contain shallow ground water that adequately subirrigates crops, and water is not spread on the surface. Most Boise River bottom land apparently is excluded from the reported irrigated area, yet it has been observed that some of this land actually is irrigated. Also, land irrigated with ground water is not included in most published estimates of the irrigated area.

According to published data the net irrigated area in the Boise Valley is substantially less than the 356,000 acres that was reported to be irrigated when the valley projects were completely constructed. Some current estimates indicate as little as 316,000 irrigated acres. Owing to private ground-water development, subirrigation, and ungaged diversions, the total irrigated acreage, however, may exceed the estimate of 340,000 acres that is used in this report. Until the acreage is accurately known, neither the duty of water nor the total consumptive use of water can be estimated accurately. Good information is lacking also on the total area occupied by native waterloving vegetation and on the amount of water consumed by such vegetation. These deficiencies in information preclude accurate determination of the water budget of the valley and of the effects that development under the alternate plan would have on that budget.

2. Data on total diversion and diversion requirements are not entirely adequate. All major diversions, including those of return water in the river and in drains, apparently are gaged. However, there may be many ungaged minor diversions, and some canals gain appreciable amounts of water by effluent seepage of ground water. The estimated aggregate volume of ungaged diversions and effluent seepage is about 200,000 acre-feet a year according to the Bureau of Reclamation, but the degree of accuracy of this estimate cannot be determined at present. Inasmuch as total diversions and net irrigated area are not accurately known, the overall gress duty of water is indeterminate.

3. The amounts of ground-water recharge and discharge in the Boise Valley and adjacent tributary areas are unknown. Estimates in this report are largely of potential recbarge and discharge, and these probably differ substantially from the actual amounts. Lack of year-round records of the increments to canals and drains from ground-water discharge, and of records of segmental loss and gain for the Boise River from Boise Diversion Dam to the river mouth, prevents accurate calculations of recharge and discharge and of the extent to which pumping a large battery of wells would influence watural ground water disoharge in to surfere drainagaways. 
4. The full extent and nature of the drainage problem in the BoiseValley are not known. The map (pl. 4) indicates the area of potential drainage problems-land in which the depth to water is less than 10 . feet. The part of such land that actually is damaged by water-. logging could be determined readily where the waterlogging is caused by unconfined shallow water. Study would be required, however, to. delineate areas where waterlogging is by upward leakage from artesian aquifers. Drainage wells would be effective only if they tapped the. water that is directly causing the waterlogging. Delineation of artesian-leakage areas would be a necessary prelude to the installation. of drainage wells under the alternate plan.

5. The alternate plan excludes from consideration the part of theBoise Valley north of the Boise River, and the present report con-. tains very little information about that part. Nevertheless the north. and south sides of the valley are geologically similar and are hydrologically inseparable. Hence, water-supply and drainage problems. are valley wide. Data are lacking on the occurrence of ground water. in the Black Canyon project, and the influence of that project on. drainage and water-supply problems in the north-side lowland is. growing. Deficiency in data of all kinds for the north side area is. an obstacle to complete evaluation of the alternate plan, or of any. other plan for comprehensive, basinwide water management.

6. Records of the discharge of the Boise River above Boise Diversion Dam, at Boise, and at Notus are adequate for their specific purposes. The gage at Notus, however, does not show the total surface. outflow from the Boise Valley. Reasonably accurate records of such. discharge would be essential to compute total ground-water recharge . and ground-water outflow from the Boise Valley. Records are lack-. ing also of the discharge of surface water in drains and ditches that are not tributary to the Boise River, but discharge to the Snake. These records are needed also to compute ground-water recharge: and outflow.

7. Lack of data on evapotranspiration in the Boise River basin: above Boise Diversion Dam precludes determination of the amount of ground water that reaches the valley lowland by underflow. The. rate of underflow estimated in this report may be materially in error, but the amount of water is small compared to the total supply in theBoise Valley.

8. Information about hydrologic characteristics of earth materials in the Mountain Home plateau is insufficient for an evaluation of" water diversion requirements for irrigation. The effects of irrigation on ground-water storage in the plateau can be surmised: only roughly from scanty subsurface information. Geologic study of the plateaus is needed. 
9. The chemical quality of water in the Boise Valley is poorly known from short-term systematic study of a segment of the Boise River, and from samples from a few wells and other sources. The distribution of chemical classes of water in the valley is known only in a very general way. The available data show that some water in the valley is undesirable in quality. The need for comprehensive information on this factor in the water-management program is obvious.

\section{GENERAI EVALUATION OF THE ALTERNATH PLAN}

The alternate plan recognizes the basic principle that, in the ultimate analysis, ground water and surface water are two components of a single resource. Failure to develop and manage both components effectively is the root of the drainage problem in the Boise Valley, where ground water has been considered largely as a nuisance. The alternate plan, in principle, proposes total water management that would turn the nuisance into an asset. Nevertheless, by ignoring the lowland north of the Boise River, the plan fails to recognize that the entire valley is a hydrologic unit. The plan also would seek to furnish usable water and drain wet land by pumping wells at sites selected arbitrarily, overlooking natural geologic and topographic factors that would control the effects of pumping.

The chief modifications needed in hydrologic features of the alternate plan would be in the pattern of well installations, the construction characteristics of wells, and the amount of ground water pumped. These modifications would change the basis for computing the cost of well construction and pumping, water delivery, drainage benefits, and other elements of the plan.

The alternate plan treats the drainage problem in the Boise Valley as an emergency. Though the drainage situation is bad and is gradually worsening, this "emergency" has existed for more than 30 years. No need is apparent for a "crash" program, initiated without adequate data and without reasonable assurance that the overall plan, even though extensively modified, is feasible. The effects of ground-water pumping on long-term water-level trends or on the flow of drains cannot be forecast with reasonable accuracy at this time. Likewise, inasmuch as water rights are well established on drain-ditch water within and beyond the exchange area, there is no basis for estimating the number of adjustments and exchanges of water rights that may become necessary. Difficult negotiations would be necessary prior to construction, to arrange for shifting points of diversion and to gain acceptance of substitute water supplies. $\mathrm{Ob}-$ viously it would be necessary to assure present water users of a supply that is adequate in quantity, suitable in quality, economically acces- 
sible, and capable of efficient delivery where it is needed. The alternate plan does not provide such assurance.

Unresolved major hydrologic problems that concern the heart of the alternate plan are in three principal categories; namely, the amount of ground water that actually must be pumped to replace live surface water and return water; the amount of ground water that is perennially available and accessible; the chemical suitability of the ground water and the water-management practices necessary to forestall an unfavorable salt balance. In the present report the necessary amount of replacement water has been estimated only crudely, and within possible maximum limits. Availability of the water seems probable, but there is reasonable doubt of its accessibility within the exchange area. Only the general dimensions of the chemical-quality problem are established. Until the problems in these categories are resolved, effective operation of the alternate plan for an indefinitely long time cannot be assured.

An intensive hydrologic study alone would not completely resolve all major problems because not all the unknown and indeterminate variables in the water equation could be eliminated. Nevertheless, attack upon the problem is not necessarily at an impasse. Intensive study and observation, along with partial execution of the alternate plan, probably would lead to a solution. A trial-and-study suggestion is outlined below.

\section{SUGGESTED PRACTICAL TRIAL AND STUDY}

The Hillcrest division, containing 12,000 acres, would require water diversions of about 60,000 to 65,000 acre-feet, depending on the duty of water and transmission losses. Construction of the Hillcrest division might be done economically, independently of the Long Tom division for the time being. Although surplus Boise River water is adequate for the Hillcrest division; replacement water nevertheless could be pumped during a trial and observation period. This would not preclude ultimate development of the Long Tom division, on a distributed-cost basis, if an ultimate feasibility finding is made. On the other hand, the Hillcrest division could be expanded and remain as a feasible independent unit if ultimately it is found that the whole plan is not feasible. In the latter event the Hillcrest division could be enlarged, if desired.

Development of the Hillcrest division would not necessarily commit the constructing or operating agency to an overall plan whose feasibility is now indeterminate. At the same time the development and operation would assure realistic appraisal of the feasibility, and accurate computation of cost of the full alternate plan, because information would be obtained on the following important factors: 
1. Duty of water for farm delivery, transmission loss, and total diversion requirement for plateau-type land.

2. Effect of application of irrigation water on the plateau, such as the development of perched water that may cause drainage problems in the new land, and the extent to which return flow may become available.

3. Suitable construction characteristics, depth, pumping lift, and production rate from one or more groups of wells in representative types of areas.

4. Drainage efficiency of pumped wells situated where pumped water can be used effectively.

5. Effect of continuous heavy pumping on the water table and on the discharge of ground water (return flow) to drains and to the Boise River.

6. Effect on the ground-water divide (near the New York Canal) of applying water to the Hillcrest division and of pumping north of the divide. Infiltration of irrigation water would tend to build up the water table beneath the Hillcrest division; this build-up, along with heavy pumping north of the ground-water divide, would tend to shift. the divide southward, thus increasing the area in which ground water is tributary to the exchange area in the Boise Valley.

7. Change of chemical quality of water within the areas of pumping ground water. The change probably would not be great during a small-scale development, but the trend of changes would be very significant.

\section{LITERATURE CITED}

Carr, James K., 1953, Alternate plan for Mountain Home irrigation and drainage project, Idaho. Memorandum report on an alternate plan, Mountain Home irrigation and drainage project, Idaho (prepared at the request of Hon. Hamer H. Budge, Member of Congress): Comm. on Interior and' Insular Affairs, Comm. print no. 4, U. S. House of Representatives, 83rd. Congr. 1st sess., $37 \mathrm{p}$.

Carter, George N., 1926, Well pumping for drainage and supplemental irrigation: in Fourth Biennial Rept. Dept. Reclamation, State of Idaho, p. 32-35.

Dean, H. T., 1936. Chronic endemic dental fluorosis: Am. Med. Assoc. Jour., v. 107, p. 1269-1272.

Eardley, A. J., 1951, Structural geology of North America: Harper and Bros., New York.

Eaton, F. M., 1950, Significance of carbonates in irrigation waters: Soil Science; v. 69 , no. 2 .

Follansbee, Robert, 1934, Evaporation from reservoir surfaces: Am. Soc. Civ. Eng., Trans. v. 99, no. 1871, p. 704-715.

Jacob, C. E., 1947, Drawdown test to determine effective radius of artesian well: Am. Soc. Civ. Engineers, Trans., v. 112, p. 1047-1070.

Jensen, M. C., Lewis, G. C., and Baker, O. B., 1951, Characteristics of irrigation waters of Idaho: Idaho Agr. Exper. Station, Research Bull. no. 19, p. 39-40. 
Kirkham, V. R. D. 1931a, Revision of the Payette and Idaho formations: Jour. Geol., v. 39, no. 3, p. 193-239, figs. 1-15.

1931b, Snake River downwarp: Jour. Geol., v. 39, no. 5, p. 456-482.

1931c, Igneous geology of southwestern Idaho: Jour. Geol., v. 39, no. 6, p. 564-591.

Lindgren, Waldemar, 1898, Description of the Boise quadrangle, Idaho: U. $\mathbf{S}$. Geol. Survey Geologic Atlas folio 45.

Lindgren, Waldemar, and Drake, N. F., 1904a, Description of the Nampa quadrangle, Idaho-Oregon: U. S. Geol. Survey, Geologic Atlas folio 103.

1904b, Description of the Silver City quadrangle, Idaho: U. S. Geol. Survey, Geologic Atlas folio 104.

Love, S. K., and Benedict, P. C., 1948, Discharge and sediment loads in the Boise River drainage basin, Idaho, 1939-40: U. S. Geol. Survey WaterSupply Paper 1048.

Meinzer, O. E., 1923, Outline of ground-water hydrology, with definitions: U. 8. Geol. Survey, Water-Supply Paper 494.

Rohwer, Carl, 1934, Evaporation from different types of pans: Am. Soc. Civ. Eng., Trans., v. 99, no. 1871, p. 673-703.

Sloan, W. G., 1953, An alternate plan for the development of Mountain Home project, Idaho. In Carr, James K., Alternate plan for Mountain Home irrigation and drainage project: Comm. on Interior and Insular Affairs, Comm. print no. 4, U. S. House of Representatives, 83rd. Congr. 1st sess., p. 22-37.

Steward, W. G., 1919, Distribution and use of irrigation waters: Joint Conf. Irrigation Engr. and Agr. Soc. of Idaho, Proc., 1918-1919, p. 177-178.

Theis, C. V., 1935, The relation between the lowering of piezometric surface and the rate and duration of discharge of a well using ground-water storage: Am. Geophys. Union Trans. v. 16, pt. 2, p. 519-524.

Thiessen, A. H., 1911, Precipitation averages for large areas: Monthly Weather Review, v. 39, no. 1, p. 1082-1084.

U. S. Bureau of Reclamation, 1950a, The Columbia River. A comprehensive departmental report on the development of the water resources of the Columbia River basin . . . : House Doc. 473, 81st Congr., 2d sess., v. 1. The preliminary report of the same title was issued by the Department of the Interior in 1947.

1950b, The Columbia River. Supplemental reports on the . . Mountain Home (Payette unit) . . . projects: House Doc. 473, 81st Congr., 2d sess., v. 2, p. 211-306.

U. S. Salinity Laboratory Staff, 1954, Diagnosis and improvement of saline and alkali soils: U. S. Dept. Agriculture Handbook no. 60, 160 p.

Wenzel, L. K., 1942, Methods for determining permeability of water-bearing materials, with special reference to discharging well methods: U. S. Geol. Survey Water-Supply Paper 887.

Wilcox, L. V., 1948, Explanation and interpretation of analysis of irrigation waters: U. S. Dept. Agriculture Circ. 784. 


\section{INDEX}

\section{Page}

Ada County, population

Agricultural statistics.

Alluvium, Recent

of Indian Creek

Alternate plan for Mountain Home project, area that could be irrigated under.

assumptions, basic

definition and background.

drainage benefits.

drainage features

$54,100,106-107$

drainage proposals

11,12

effects of, on quality of water

water levels.

water regimen.

water rights

water table.

53,65

$90,108,110$

62,113

$61,95-100$

elements, principal. ...................... 108-110

feasibility . ................................ 90-107

ground-water features. ................... 12

limitations . ............................... 49-90

limiting ground-water conditions .......... . 50-53

modifications noeded . .................... 108, 113

power-generation features.................... 11,96

problems, unsolved......................... 114

proposals, basic.................. 90-92

pumping season........................ 102-103

surface-water features........................ 11-12

water rights............................... 113

wells, cost of ........................... 61, 68, 106

Anderson Ranch Dam, function............. power production

Anderson Ranch Reservoir...................... 8, 8 capacity................................. 9,36

storage space for irrigation................ 95

Aquifers, artesian.

in Eagle Island

in Meridian district.

in Nampa district

characteristics.

$54-57$

hydraulic coefficients...................... 55,57

at Ellis farm

in Ustick-Meridian area................... 57,67

tests of, in Eagle Island.................... 69

Arrowrock Dam and Reservoir, function..... $\quad 8,9$

cepscity -................................. 9,36

evaporation ............................... 29

precipitation. ............................. 31

Artesian ground water. See Ground water, artesian.

Barber Diversion Dam, function. ............ power production.

Basalt, Columbia River..........................

Black Canyon Dam, power production at....

Black Canyon Project, relation to drainage

problem in Boise Valley.

48,112

Boise Diversion Dam, function....... 8,0

power production at........................ 14

Boise Project.
Boise River, depletion of . . . . . . . . . . . . . 40-41 discharge, at Boise Diversion Dam ....... $\quad 36$

at Notus gage. ....................... 40

characteristics of ...................... 33

diversions from ............... 15, 16, 36, 39, 95, 111

diversions, ungaged....................... 111

flow, residual, past Notus . . . . . ......... 39-40

gains to, above Notus. .................... 40

inflow, tributary ........................ 37

regulation .............................. 36

runoff in ..................................... 14-15

South Fork of, discharge by ............... 95

Boise River basin, storage and diversion

works.

Boise River water, availability for Mountain

Home project...

to Lake Lowell

depletion of .................................. 41

disposition of ........................... 16

diversions ................... 15, 16, 36, 39, 95, 111

exchange of............................. 11, 96, 98

export_................................ 38

return-flow component. .................. 15

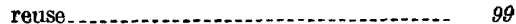

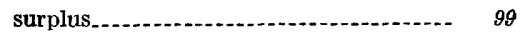

utilization............................ 14-16,39-40

Boise Valley, agriculture and industry...... 12-18

depth to water . ..................... 32, 37,62-64 drainage problems in . .......... $9,57,65,112,113$

drains, miles of ........................... $g$

economic development.................. 12-18

electric-power supply ....................... 13-14

ground water, accessibility . ............. 102-108 depth to........................ 32,37,62-64

occurrence...................................... $35-88$

ground-water districts................... $50-53$

ground-water recharge .................. 44, 46-47

ground-water yield. ..................... 41

irrigated area...................... 8, 28, 41, 111

irrigation with ground water............. 8,37

physical character.................... 18

population . . .

precipitation . ................... 24, 25,31

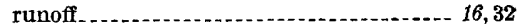

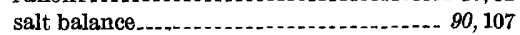

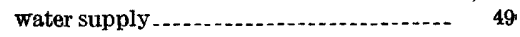

water, consumptive use................. 40

diversions _..................... 15, 16, 36,93

duty of

exchange. . . . . .

export_.................................. 39

farm delivery

full supply .............................. $\quad 36$

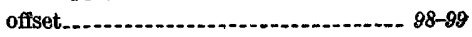

pattern of supply.................... $85-88$

quality of water................. 70-81, 107 
Boise Valley-Continued

Page $\mid$ Eastern upland. See Upland, eastern.

replacement.

100-101

total supply

$38-89,49$

usable supply.

$89-40,49$

wells, average yield

51,52

Boundary, hydraulic distribution of

37-38

effect on pumped wells.

in Ustick-Meridian area...................

Broadway terrace, depth to water beneath....

Canals, percolation from effect of, on pumped wells.

66,104

Canyon County, population

Canyon Creek.

Canyon Creek basin.

Carr, James $\mathbf{K}$

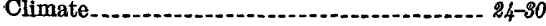

Coefficients, of storage 92a, $93 \ldots \ldots \ldots \ldots \ldots$ of transmissibility 93 .

See also Aquifers.

Columbia River basalt

Contributing area. $19,22,23$

Cottonwood Creek, runoff

Data, basic, lack of.

Deer Flat Reservoir. See Lake Lowell.

Depletion, of Boise River. of ground water.

. $47-48$

Depth to water. See Ground water, depth to.

Development, economic, in Boise Valley ...- 8, 12-17

Diversions, from the Boise River _. 15,16,36,39,95,111 in Bojse Valley........................ 15, 36, 93 ungaged.

111

Diversion requirement for Mountain Home project.

92-95

Drainage, effectiveness of, pumping ground water for effectiveness of, coupled with groundwater irrigation. $9,60,68$ in Pioneer Irrigation District.......... 9,65 in Ustick-Meridian area................. 68 on Ellis farm........................... 67 by surface drains..................... $9,48,112$ feasibility of, coupled with pumping for irrigation .................................... 65

in areas having perched ground water -.............................. 68-69 under the alternate plan............. 11, $58-54,100-101,106$

Drainage problems, cause of .................. 4,37 in Boise Valley $11 \ldots . . .9-11,37,65,66,67,112,113$

effects of Black Canyon Project....... 48, 112 in Meridian district........................ 51 in Nampa-Meridian Irrigation District... $\quad s 7$ in Nampa district......................... 51 in North side district........................ 38 in Pioneer Irrigation District................ $\quad 87$ in Wilder district........................... 52

Drainage wells. See Wells.

Drains, surface ................................... 9,48

Dry Creek, runoff in.......................... 40

Duty of water, for Boise Valley lands......... 37,111 for proposed Mountain Home project..... $9 s$

Eagle Island, aquifer tests..................... 69-70 artesian water.......................... 51,69 Idaho formation........................... 51, 69 yield from wells. . ......................... 69, 70
Eaton, F. M., quoted.................... 78

Electric-power supply ............................ 13-14

Ellis farm, drainage by pumping from wells..- 66,67 hydraulic coefficients of aquifers............ $\quad 57$ subsurface conditions........................ 66 test well...................................... 66 waterlogging, cause of ..................... 65

Elmore County, population.................. 13 Evaporation

Evapotranspiration............................ $\quad 29$

Exchange-pumping area, definition.........-- 44 precipitation, disposition................... 44

Fluoride in water, effect of ................... 70, 81 from Idaho formation....................... 82 from volcanic rocks........................ 82

Garden Valley reservoir . ............. 7

Geologic control of water...................... 19 in Boise Valley ............................... 20 in Mountain Home Plateau ............... 20

Gradient, thermal, in Boise Valley.......... 73

Gravel packing of wells..................... 60

Ground water, accessibility in Boise Valley _ 102-103 area irrigated with ......................... 16 artesian, at Ellis farm . . . .

in Eagle Island.......................... 51, 69

in Idaho formation. .................... 53

in Kuna district...................... 52

in Meridian district. .................. 51

in Nampa district..................... 50,51

in North side district................... 53

in Pioneer Irrigation District.......... $\quad 65$

in Ustick-Meridian area................ 68

availability of ............................... 101 chemical types............................ 70 consumptive use of ........................ 47, 102 depletion........... 47-49, 101 depth to, changes in....................... 64

in Boise Valley................... 32, 37, 62-65

in Broadway terrace................... 32

in Meridian district. . . .................. 51

in Mountain Home plateau ............. 32

in Nampa district...................... 51

in Pioneer Irrigation District. ......... 65

in Whitney terrace .................... 32 discharge, by surface drains ................. 48, 111

to Boise River.......................... 33 effect of irrigation on ................... 33, 62-64 exchange of, for surface water............ $97-101$ exchange-ratio for fluoride in ................................ 70, 81, 82 geologic control of . ...................... 41,42 irrigation with, in Boise Valley............ 8, 37 movement of ................................ 61 occurrence in Boise Valley .................. 50-53

Eagle Island........................... 51

Kuna district............................. 52

Meridian district........................ 51

Mountain Home plateau ........ 34-85, 39, 94

Nampa district......................... 50-51

North side district......................... 58

Sunrise terrace........................... 32

valley of Snake River................... 52

Wilder district.......................... $\quad 62$

perched $68-69$ 
Ground water-Continued

pumping for drainage.

for irrigation

for municipal supply. ............... 17 quality of $70,81,82,107$

recharge, by underflow

$41-47,101,111$

in Mountain Home plateau. . . . 32, 47, 61, 101 relation of, to drainage problem........... 10 replacement, total replacement pumping..-.................. 38 salinity hazard ............................ 107 sodium-adsorption ratio . .................. $\quad 78$ sodium carbonate, residual ................ 78 sodium hazard . ......................... 78, 107 sodium, percent. $75-77$

suitabllity of, for irrigation . ....... 70, 73, 107-108

criteria for evaluating supply of, total. temperature uncommitted................................ 101

use of, in Boise valley . .

on Mountain Home plateau withdrawals................................ 47

Ground-water conditions limiting alternate plan

Ground-water districts ......................

Ground-water divide ....................... 61, 104

Ground-water recharge. See Recharge of ground water.

Growing season, length of precipitation during

Highland, northern (see Northern highland).

Hillcrest division, effect of irrigation.

plans for

trial development . . . . .

water supply available.................. 95

Hubbard Reservoir .......................... 8

Hydraulic boundaries in Ustick-Meridian area.

Hydraulic coefficents of aquifers, at Ellis Farm

at Ustick-Meridian area

Hydrophytes, use of water by.

Idaho batholith. ........................... 19, 23, 43

Idaho formation............................... 19, 22

as aquifer, in Eagle Island................. 51,69

in Meridran district. .................

in Nampa district.

in North side district.

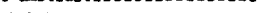

fluoride in water from . ................... 82

in northern highland. .................... 43

Indian Creek, alluvium of, as aquifer in Nampa district.....................

discharge of $\quad 35,36$

Industries.................................... 12

Iron, relation to quality of water............... 81

Irrigated area, in Boise Valley....... 8, 26, 28, 41, 187 served by ground water................... 16

Irrigation, effect of, on water levels............ 46 effect of, on ground water............ 33, 62,64,65 of Hillerest division ......................... 34 on Mountain Home plateau.
Irrigation-Continued pumping of ground water for, feasibility of, coupled with drainage by pumping $64,65,69$

in Boise Valley............. 9, 10, 11, 33, 37-38 suitability of water for .................. 70,81, 107

Kuna district, ground water conditions........ 52,89 yield of wells ................................. 89

Lake Lowell, delivery of water to............. 96 evaporation at............................... 29,41 function................... 8, ground-water divide near.................... 61 percolation from.......................... 96 surface drainage south of.................... 61

Little Camas Reservoir, diversion of water from

Long Tom diversion dam, power generation at 11-12 Long Tom division, plans for................ 8-9,11 water available for.......................... 95

Long Tom Reservoir .......................... 8

Lucky Peak Dam, function.................. 8,8 power-generation.......................... 9,12

Lucky Peak Reservoir, capacity of............ 9, 36

Main canal. See New York Canal.

McKay, Douglas_................................

Meridian district, ground water and drainage. 51

Moore Creek tunnel........................... 7-8

Mountain Home plateau, locatjon.......... 3-4, 17 altitude....................................... 31 depth to ground water escape recharge......................... 47, 61, 101 ground water..................... 17, 32, 35, 62, 94 ground-water quality

irrigation ................................... 15

physical character.......................... 18

precipitation . . ............................... 31, 32

soil... 93

surface drainage........................ 32, 34-35

surface-water yield. .......................... 15

water-supply pattern................... 20, 34-35

water utilization............................ 14

Mountain Home project

alternate plan .............. 5, 7, 11,90-92, 108-110

availability of water....................... 95

diversion requirement. ................ 98-9s, 94-95

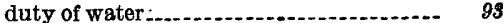

Long Tom division...................... 7,11

original plan................................. 5, 7-8

Payette unit................................. 7,11

See also Alternate plan for the Mountain

Home project, and Original Plan for the Mountain Home project.

Nampa district, alluvium of Indian Creek in.

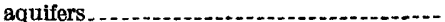
artesian ground water.

depth to water. drainage problem................................

Idaho formation.

Younger terrace gravel ...................... wells, yield from drainage in 
New York Canal, effect of pumping wells near. $\quad 105$ ground-water divide near................ 61,105 percolation loss.......................... 47, 61 relation to water table.................... 105

Northern highland, contributing area of...... ground-water yield from. precipitation. surface runoff

North side district, drainage problem ground water

Idaho formation. .............................. relation to alternate plan. wells, yield of.

Notus, fiow of Boise River at_........... 39, 40 Orchard Reservoir.......................... 8

Original plan for Mountain Home project.... $\quad 5,7$

Owyhee batholith.......................... 19,23

Owyhee Mountains. ........................... 19

Owyhee rhyolite................................ 19, 22

Payette formation........................... 19, 22

Payette River, diversion of water from ....... 7-8 effect of importing water from............ 48

Payette River basin, diversion of water from.

Payette unit of Mountain Home project...... 7-8, 11

Perched ground water, drainage............. 68-69

Percolation, from canals........................ 47, 61

from Lake Lowell . . . ......................... 96

Phreatophytes, use of water ................. 48

Pioneer Irrigation district, depth to water.... 65

need for drainage .......................... 37

wells, pumped, drainage by ..............

drawdown in .......................... 104-105 yield from

Pleasant Valley Reservoir........................

Population in Boise Valley..

Power plants, capacity

Precipitation, amount

at Arrowrock Dam

at upland stations.

consumptive use of

disposition of, in exchange-pumping area .

on Boise River basin. . .................

on eastern upland.

on northern highland.................. 49,44

during growing season

effect on water-levels

in Boise River basin

$24-25,31$

in eastern upland

on Mountain Home plateau.

volume, in Boise River basin

on northern highland

Pumping, effect of, on water levels.

effect of, on water regimen

Pumping season under the alternate plan

e plan....

Pumping tests, in Boise Valley

in Ustick-Meridian area effect of irrigation on

effect on operation of alternate plan

in Mountain Home plateau

70

pattern of, in Boise Valley.

$81,82,107$

suitability of, for irrigation.

70,107
Quality of water-Continued

Page

surface water .............................. 70, 75

from Snake River. . . .

pattern of . . ............................. 82-84

variations.............................. $70,81,83$

Rattlesnake Creek . . . . . .

Recharge of ground water, by underflow ....- 41-47,

101,111

from irrigation......................... 40, 46,101

from precipitation......................... 44

in Boise Valley ........................ 44,46-47

in Mountain Home Plateau........ 32, 47,61, 101

Replacement water, availability............... 100 chemical suitability of..................... 107

Ridenbaugh Canal. .......................... 66, 104

Runoff, from eastern upland................... 32

from northern highland ...................... 43

in Boise Valley .............................. 32

in Cottonwood Creek.................... 40

in Dry Creek.................................. 40

on Mountain Home plateau............... $\quad 32$

Salinity hazard, from ground water ............ 107

from surface water......................... 78

Salt balance, in Boise Valley .................. 90, $10 \tau$

Silica, relation to quality of water............ 81

Snake River, availability of water from....... $\quad 96$

discharge..................................... 34

exchangeability of water................... 96

proposed pumping from ................. 11

quality of water from

replacement water from . . . . . .............

valley of the.............................. 16, 17

ground water in ...................... 34

water-supply pattern in............... 34

Snake River basalt, characteristics............. 21

in Nampa district. ......................... 50

occurrence of ............................ 19, 21

Sodium-adsorption ratio, in ground water... 78

use for evaluating water................... 75,78

Sodium carbonate, residual, in ground water.- 78

in surface water ......................... 78

relation to irrigation..................... 75,78

Sodium hazard, evaluation of ................ 75,78 . from ground water.................... 75, 81, 107

from surface water ...................... 75

Sodium, percent. . . . . . .

South Fork of Boise River. See Boise River, South Fork of.

Specific capacity of wells ..................... $\quad 57$

Specific conductance, irrigation water, electrolytic corrosion, relation to...... $\quad 73$

Specific yield of aquifers..................... 54

Statistics, agricultural .................... 13

Storage, coefficient . . . . . .

Storage space, active, in Anderson Ranch Reservoir ........................... 36.

active, in Arrowrock Reservoir. .......... 36

for irrigation, in Anderson Ranch Reservoir ............................ 95

Storage works in Boise Rjver basin........... 8

Strike Dam, C. J., power production........ 14

Sunrise terrace, ground water beneath........ 32

Surface water, area irrigated................. 41

availabllity .............................. 95

chemical types................................ 70

consumptive use . . . . . 
Surface water-Continued Page depletion

quality

residual sodium carbonate

sodium-adsorption ratio.

surplus.

total supply.

usable supply ................ 39-40

utilization.

under alternate plan

variations in quality

Swan Falls.

Swan Falls Dam, power generation

Temperature, of ground water

in Boise Valley counties. ...................

mean annual, at Boise .....................

Tenmile Creek

Test wells. See Wells, test.

Topography, influence on water supply

Transmissibility, coefficient of .................

Transpiration in Boise Valley ...................

Upland, eastern, ground-water yield. precipitation

runoff water yield

Upland stations, pr

Ustick-Meridian area boundaries, hydraulic coefficients, hydraulic, of aquifers......... drainage of, by pumped wells tests, pumping

Water, chemical types

consumptive use.

in Boise Valley

$40,41,48$

in eastern upland

in northern highland. ................ deptb to. See Ground water, depth to. duty of, in Boise Valley

$36-37,111$ exchange of, for Boise Valley

from Boise River 16

95,96

exporting of, from Boise Valley

farm delivery

full supply of, for Boise Valley

geologic control................................

imported, from Payette River .............

offset, for Boise Valley ....................... 98-99

live, definition.

diversions

menagement

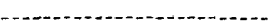
replacement, for Boise Valley _..... 38, 97, 100 replacement, total. $100-101$ suitability for irrigation

$80,81,107$ total supply in Boise Valley. ............ 39, 49 uncommitted.............................. 101 utilization in Boise Valley. usable supply in Boise Valley. use by the alternate plan.

by hydrophytes and phreatophytes

by water-loving plants.

on Mountain Home plateau

See also ground water and surface water.

\section{W}

Water-level fluctuations, causes.

by precipitation

by pumping.............................. 64

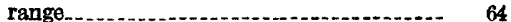

Water-loving plants, use of water............. 48,112

Water regimen, effect of alternate plan.... 61, 96,100

Water rights, exchange and adjustment....... 113

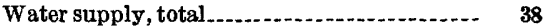

for Hillerest Division...................... 95

of ground water in Boise Valley. . . . ...... 48-49

Water table, configuration................... 32

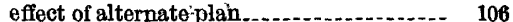

lowering of, by pumping.................... 53-54

relation of, to New York Canal .......... 104, 105

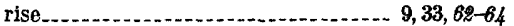

Well-numbering system .................... 7

Wells, capacity

characteristics of, in Boise Valley ........ 37, 105

under alternate plan.................. 103-107

cost under alternate plan. ............... 61, 107

development............................. 61

distribution of, in Boise Valley ........... 37-38

drainage, effectiveness.......... 53-54,61,65, 106

drawdown from pumping .......... 54, 57, 104-105 dual-purpose, effects of, on natural groundwater discharge . . ................. 111

efficiency of $\ldots \ldots \ldots$...................... 65,106

effects of, on canals ............... 104, 105

gravel packing ............................. 60

interference between................. 57, 104-105

performance............................ $\quad \boldsymbol{b}^{7}$

pumping tests............................. 54

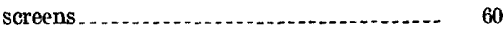

specific capacity ...................... 57,50

yield, assumed average . ................... 12, 60

at Ellis farm

in Boise Valley......................... 57,60

in Eagle Island...................... 57, 69,70

in Kuma district ...................... 52

in Meridian district.................. 51,55

in Nampa district................... 50, 51, 55

in North side district................... 55

in Pioneer Irrigation District.......... 57

in Ustiok-Meridian area:_.............. $\quad 57$

in Wilder district........................ 52

under alternate plan..................... 106

Whitney Terrace, depth to water.............

Wilder district, drainage conditions............ $\quad \mathbf{5 2}$

ground water................................. 52

Idaho formation........................... 52

Older terrace gravel.

yield from wells. . . . . .

Wind, in Boise area . ......................... 29

Younger terrace gravel, description........... 19-21

in Nampa district........................ 50

in wilder district . . . . . . 